NATIONAL LABORATORY

MANAGEDBYUT-BATTELLE

FORTHEUS.DEPARTMENTOFENERGY

\title{
High Temperature Materials Laboratory Annual Report
}

\section{FY 2005 (October 1, 2004-September 30, 2005)}

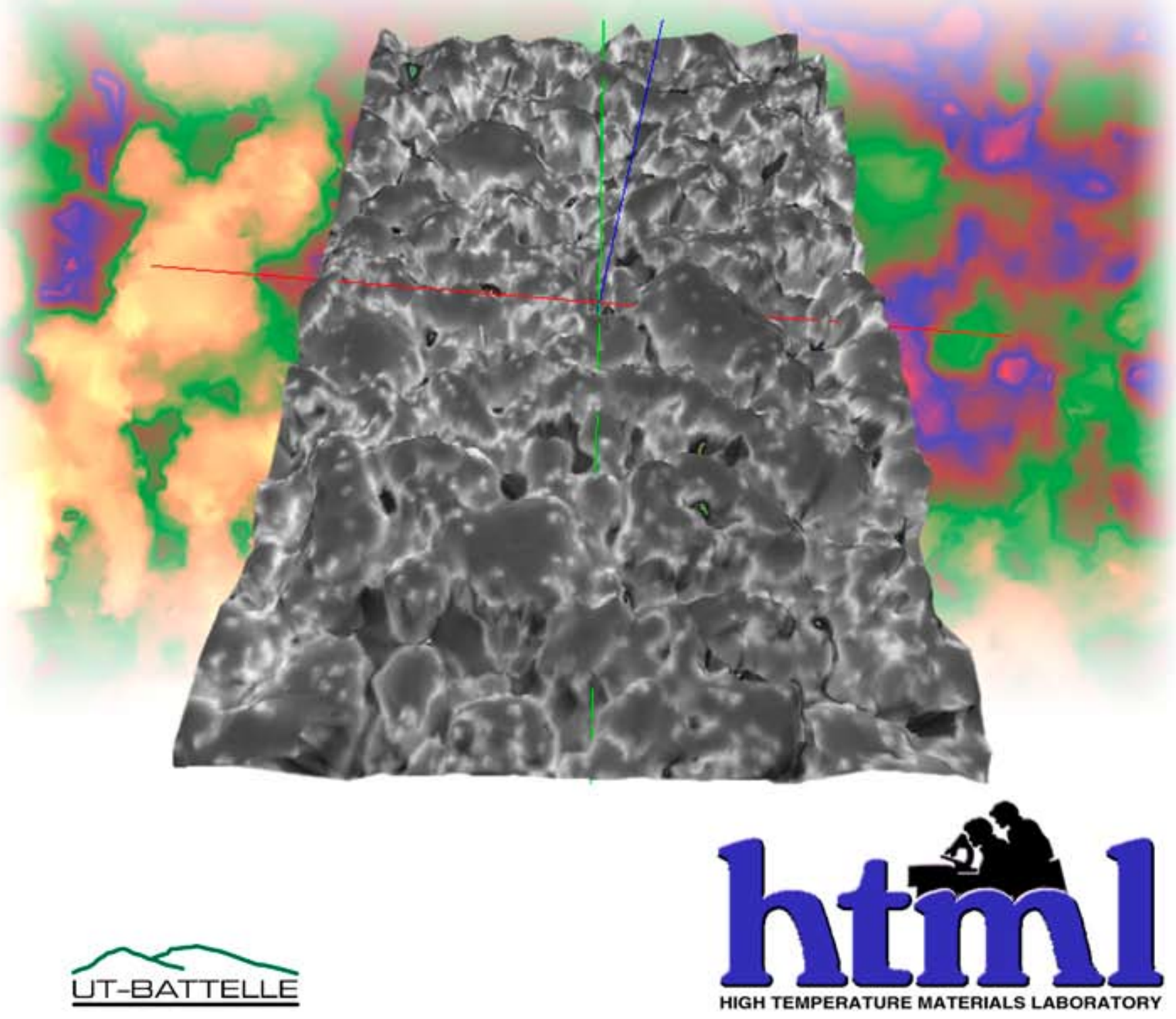




\section{DOCUMENT AVAILABILITY}

Reports produced after January 1, 1996, are generally available free via the U.S. Department of Energy (DOE) Information Bridge.

Web site: http://www.osti.gov/bridge

Reports produced before January 1, 1996, may be purchased by members of the public from the following source.

National Technical Information Service

5285 Port Royal Road

Springfield, VA 22161

Telephone: 703-605-6000 (1-800-553-6847)

TDD: $703-487-4639$

Fax: 703-605-6900

E-mail: info@ntis.gov

Web site: http://www.ntis.gov/support/ordernowabout.htm

Reports are available to DOE employees, DOE contractors, Energy Technology Data Exchange (ETDE) representatives, and International Nuclear Information System (INIS) representatives from the following source.

Office of Scientific and Technical Information

P.O. Box 62

Oak Ridge, TN 37831

Telephone: 865-576-8401

Fax: 865-576-5728

E-mail: reports@osti.gov

Web site: http://www.osti.gov/contact.html

This report was prepared as an account of work sponsored by an agency of the United States Government. Neither the United States Government nor any agency thereof, nor any of their employees, makes any warranty, express or implied, or assumes any legal liability or responsibility for the accuracy, completeness, or usefulness of any information, apparatus, product, or process disclosed, or represents that its use would not infringe privately owned rights. Reference herein to any specific commercial product, process, or service by trade name, trademark, manufacturer, or otherwise, does not necessarily constitute or imply its endorsement, recommendation, or favoring by the United States Government or any agency thereof. The views and opinions of authors expressed herein do not necessarily state or reflect those of the United States Government or any agency thereof. 
ORNL/TM-2006/41

High Temperature Materials Laboratory

18TH ANNUAL REPORT

OCTOBER 1, 2004, THROUGH SEPTEMBER 30, 2005
A. E. Pasto
B. J. Russell

Published April 2006

\begin{abstract}
Research sponsored by the U.S. Department of Energy

Assistant Secretary for Energy Efficiency and Renewable Energy

Office of FreedomCAR and Vehicle Technologies

as part of the
\end{abstract}

High Temperature Materials Laboratory User Program

1000 Independence Avenue SW

Washington, DC 20585-0121

Oak Ridge National Laboratory

P.O. Box 2008

Oak Ridge, Tennessee 37831-6285

managed by

UT-Battelle, LLC

for the

U.S. Department of Energy

under contract DE-AC05-00OR22725 



\section{CONTENTS}

LIST OF FIGURES................................................................................................ vii

ACRONYMS AND ABBREVIATIONS …..................................................................

ADVANCED MATERIALS CHARACTERIZATION AT THE HIGH TEMPERATURE

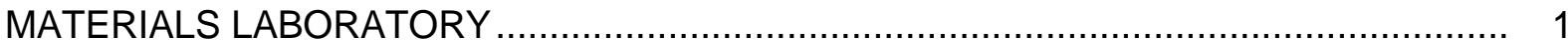

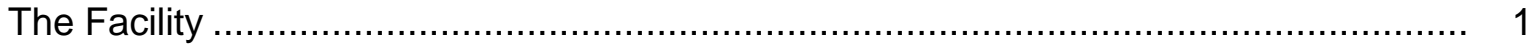

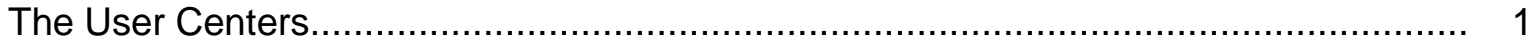

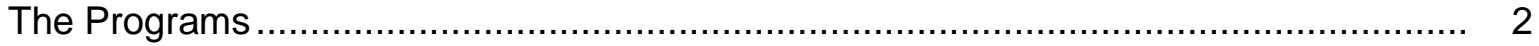

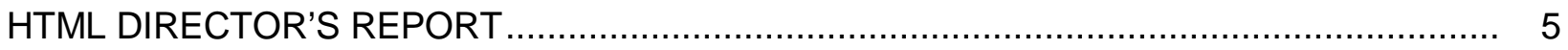

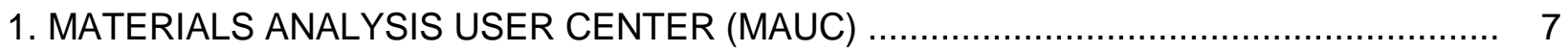

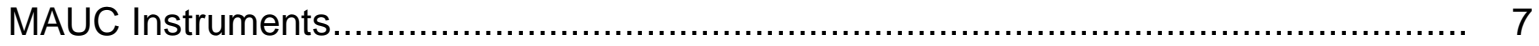

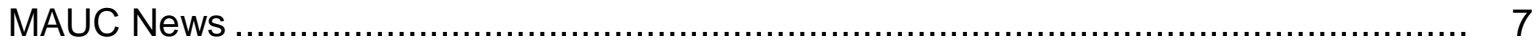

ACEM Results Win Physical Sciences Poster Contest at Annual

Microscopy Society Meeting in Honolulu......................................................... 7

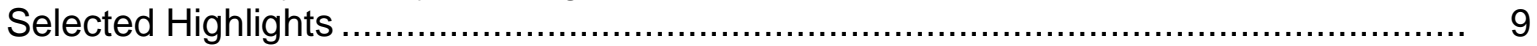

Imaging of Oxygen Atomic Columns in Perovskite Materials ................................. 9

Structure and Morphology of a Uniform-Sized Nanoscale Bimetallic Catalyst........... 9

Scanning Auger Microscopy of Alkylated Crystalline Silicon(111) Surfaces.............. 11

2. FRICTION, WEAR, AND MACHINABILITY USER CENTER (FWMUC) …....................... 13

MITUC Renamed FWMUC …………………………………………….... 13

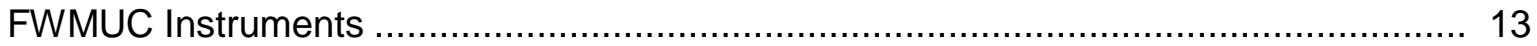

New Machine Tool Will Support Grinding Research .......................................... 13

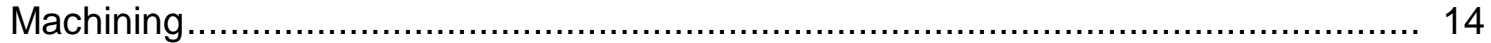

Measurements of Form, Roughness, and Subsurface Damage ............................ 14

Friction, Lubrication, and Wear Testing ........................................................... 14

New Method for Abrasion Testing …….......................................................... 14

Selected Highlights ......................................................................................... 15

Two University Projects Investigate Single-Point Diamond Turning of Ceramics ............................................................................ 15

Novel Coating Improves the Frictional Performance of Cast Amorphous Alloy ................................................................................ 16

FWMUC Collaborates with PNNL in Research on Fuel Injector Materials for Hydrogen Internal Combustion Engines .................................................... 17

Deloro-Stellite Evaluates Scuffing of Alloys for Exhaust Gas Recirculation Systems ……........................................................................ 17

3. MECHANICAL CHARACTERIZATION AND ANALYSIS USER CENTER (MCAUC).......... 19

MCAUC Instruments ................................................................................. 19

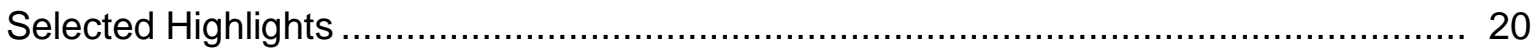

Effect of Sr Addition on the Solid-Solution Strengthening of Mg-Al-Ca Alloys ............ 20

Machining-Induced White Layers in Steels for Automotive Components ................... 21

Hy-Tech Corp. Develops a Coating to Improve Implant Durability ........................... 22

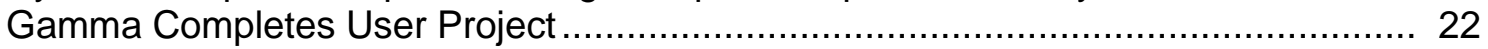

Deformation Induced by Equal Channel Angular Processing (ECAP) ...................... 23 
Pratt \& Whitney Characterizes the Constituents of Ceramic Matrix Composites......................................................................................... 23

Fracture Behavior of $\mathrm{Si}_{3} \mathrm{~N}_{4}$ Reinforced with Nanotubes .................................. 24

Mechanical Properties of Biodegradable Antimicrobial Chitosan Films..................... 25

Bonded Magnets for Automotive Applications ................................................. 26

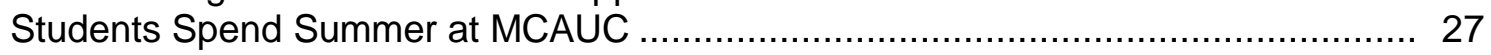

Lara-Curzio Chairs Symposium................................................................... 27

4. DIFFRACTION USER CENTER (DUC) …….................................................... 29

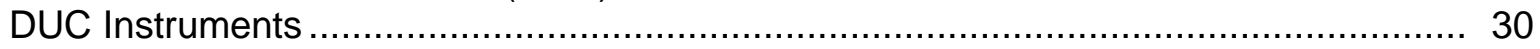

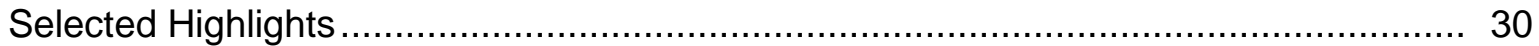

Purdue Examines Stability of YSZ Topcoats for Gas Turbines ............................. 30

Hydrogen Separation and Hydrogen Storage Materials Studied

In Situ At HTML ....................................................................................... 30

Tennessee Tech Studies Freezing and Melting of Water in Cement ....................... 31

Georgia Tech Studies Low Thermal Expansion Ceramics.................................... 31

CTI Molecular Imaging Determines the Composition of Lutetium

Aluminate Crystals.................................................................................... 31

AIN Thin Films Characterized by High-Temperature X-Ray ReflectivityUniversity of Florida .................................................................................. 32

Palladium-Based Membranes Studied in Hydrogen by In Situ X-Ray Diffraction .................................................................................. 32

HTML and Georgia Tech Organize Workshop on High Temperature X-Ray Diffraction .................................................................................... 33

HTML Participates in High-Resolution Powder Diffraction Short Course .................. 33

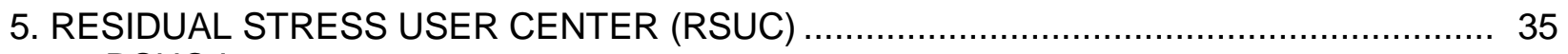

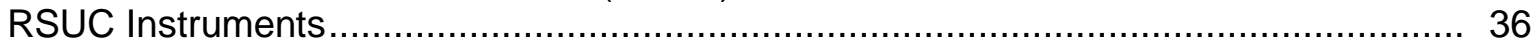

Leveraging Major Research Facilities.......................................................... 36

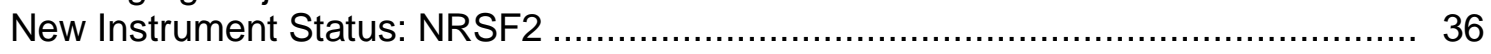

Two LDRD Projects Awarded for FY 2005 Involve NRSF2-RSUC ......................... 38

Load Frame for In Situ Mechanical Testing at NRSF2 Successfully Tested and Applied for User Projects ............................................................ 38

In Situ Real-Time Neutron Diffraction Study of Materials Behavior under Thermally Induced Stresses Demonstrated ........................................... 40

Selected Highlights ......................................................................................... 41

Marlow Industries Measures Texture at Elevated Temperatures in Shape Memory Alloys Using a New Heated Stage Designed by

RSUC for Use on 4-axis Diffractometers-Marlow Industries ............................. 41

RSUC Assists Tennessee Tech with Cement-Based Materials Research ................. 42

RSUC Assists with Retained Austenite Determinations-Georgia Tech....................... 42

The Effect of Overload on the Fatigue Crack Growth Behavior of the 316 Stainless Steel—University of Tennessee .............................................. 44

Neutron Diffraction Residual Stresses Mapping of Cylinder Liners in

Automobile Engine Block - Third Wave Systems, Inc. ………......................... 45

The Effect of Welding Process on the Residual Stress Distribution in Welded Cruciform Parts-Caterpillar Technical Center ....................................... 46

\section{THERMOGRAPHY AND THERMOPHYSICAL PROPERTIES USER}

TTPUC Instruments. 


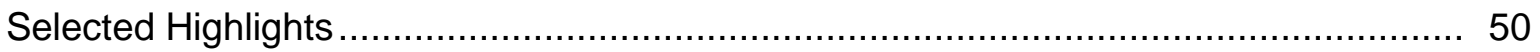

TTPUC Staff Visited Ford Chicago Assembly Plant............................................ 50

TTPUC to Participate in Thermoelectric Study of Vehicle Waste Heat Recovery ............................................................................... 50

Researchers from UAB and NASA Marshall Center Studied Thermal

Transport Properties of Liquid Semiconductors ............................................ 51

MIT Studied Thermal Transport Properties of Nanofluids .................................... 51

St. Gobain Conducted Thermal Transport Studies of Zirconia-Based Ceramic ......... 52

UMR Studied UHTC Using Thermal Diffusivity System ..................................... 52

Unifrax Studied High-Temperature Fire-Resistant Materials................................. 52

Southern Illinois University Evaluated Thermal Conductivity of

Porous Membranes ………………................................................... 53

TTPUC Staff Participated in International Thermal Conductivity Conference............. 53

TTPUC Staff Conducted Off-Site Weld Inspection at the Ford Chicago

Assembly Plant...................................................................................... 53

GM R\&D Center Performed High-Temperature Characterization of

Thermoelectric Materials ......................................................................... 54

State University of New York at Stony Brook Started Studies of Thermal

Barrier Coating at TTPUC......................................................................... 55

STANDARD NONPROPRIETARY USER AGREEMENTS …….................................. 57

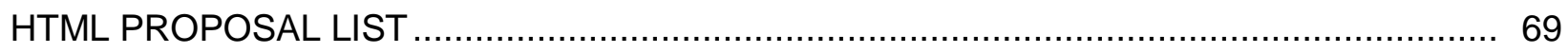

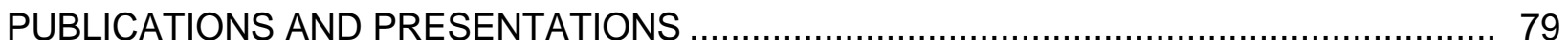

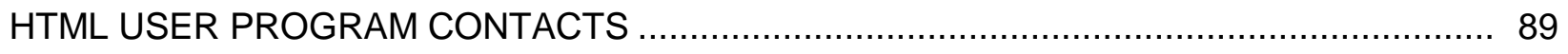

HTML STAFF AND PHONE NUMBERS ……………............................................. 91 



\section{LIST OF FIGURES}

1 Plot showing HTML User Program growth through user agreements and user proposals

1-1 First-prize poster in Microscopy Society of America Physical Sciences

Division poster contest, 2005

1-2 (a) Dark-field image of tri-rhenium clusters on alumina ......................................... 8

1-3 ACEM as seen from the control room............................................................... 9

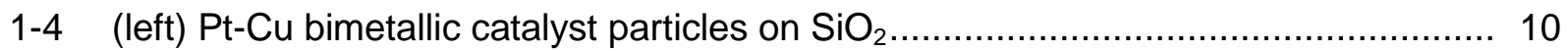

1-5 EDS spectra (overlapped) of the Pt-Cu catalyst, computed at a

$1: 1$ atomic ratio

1-6 Scanning auger elemental maps for $\mathrm{Si}$ and $\mathrm{O}$ (upper left and right, respectively), an overlay of both (lower left), and a secondary electron (SEM) image (lower right)

2-1 A new Chevalier programmable surface grinder was purchased in FY 2005 ............ 13

2-2 Single-point turning of a silicon nitride disc on the Precitech 2000 DTM.................. 15

2-3 A reciprocating friction and wear testing apparatus was modified to hold dental files

2-4 The magnitude of the sliding friction coefficient, which relates to frictional heating, was reduced through the use of the novel Better than New treatment (upper bars)

2.5 Torque generated from tile/pin wear pairs .......................................................... 18

3-1 Dr. Akane Suzuki .................................................................................. 20

3-2 Change in the 1\% flow stress of $\mathrm{Mg}-5 \mathrm{Al}-3(\mathrm{Ca}, \mathrm{Sr}$ ) alloys with $\mathrm{Sr}$ addition, measured by compression method at $\mathrm{RT}$ and $175^{\circ} \mathrm{C}$

3-3 Change in the hardness and elastic modulus of the $\alpha-M g$ phase of the $\mathrm{Mg}-5 \mathrm{Al}-3(\mathrm{Ca}, \mathrm{Sr})$ alloys with $\mathrm{Sr}$ content, measured by nanoindentation

3-4 Georgia Tech graduate student Sangil Han

3.5 Sample $1045 \mathrm{~A}$ machined at $300 \mathrm{~m} / \mathrm{min}$ showing the hard white layer, the transition layer and bulk material.

3.6 Hardness of samples $1045 \mathrm{~A}$ and $52100 \mathrm{H}$, machined at $300 \mathrm{~m} / \mathrm{min}$, at three different locations. 
3-7 Gamma engineer Denny Ross (left) with MCAUC's Bill Hendrich, preparing a burst strength test

3-8 SiC duplex structure at the end of burst strength test ................................... 23

3-9 Grigoreta Stoica, University of Tennessee ................................................ 23

3-10 Location of nanohardness measurements obtained in a billet deformed by ECAP

3-11 Micrographs of Sylrami® fiber-reinforced ceramic matrix composite containing a $0.1-\mu \mathrm{m}$-thick BN coating around each fiber

3-12 Rice University graduate student Erica Corral and MCAUC's Amit Shyam.............. 25

3-13 SEM micrograph shows crack bridging in SWCNT-reinforced silicon nitride............ 25

3-14 Prof. Svetlana Zivanovic, University of Tennessee, Knoxville, (right) and graduate student Gagan Rajpal performing dynamic mechanical analysis of chitosan thin films.

3-15 Storage and loss moduli of chitosan.

3-16 Ohio State University student Chris Clarke evaluating the four-point bending strength of bonded magnets....

3-17 Effect of processing conditions on the four-point bending of bonded magnets 26

3-18 Photograph of bonded test specimen M20979-M after compression testing.

3-19 Student research assistants. Upper left: Chris Green. Clockwise:

George Nelson, Reeshemah Burrell, and Sid Pathak.

4-1 Degradation of $\mathrm{YSZ}$ at $800^{\circ} \mathrm{C}$ caused by vanadium oxide contamination

4-2 X-ray reflectivity patterns collected from AIN thin film at $25^{\circ} \mathrm{C}$ (red), $700^{\circ} \mathrm{C}$ (green), and $1000^{\circ} \mathrm{C}$ (blue).

4-3 Pd-Ag grain growth as a function of time.

4-4 Short course participants getting hands-on experience with synchrotron based powder diffraction at HTML's synchrotron beamline

5-1 (left) The seven linear position-sensitive detectors in the mounting frame during installation on NRSF2.

5-2 (a) RSUC team members after successfully mounting the new load on the NRSF2 instrument.

5-3 (a) Macroscopic stress-strain curve of an Al-2024 alloy measured using the new NRSF2 load frame 
5-4 Setup of the heat gun and 6061 aluminum plate on the NRSF2 neutron strain-mapping instrument.

5-5 Comparison of direct and quasi-steady state measurements shows

the equivalence of the two methods

5-6 The new elevated-temperature stage (inset) mounted on the 4-axis

X-ray goniometer provides new RSUC capabilities for stress and

texture measurements at elevated temperature

5-7 Diffraction patterns of the Ni50Ti50 shape memory alloy showing

transformation from monoclinic to cubic for temperatures above $130^{\circ} \mathrm{C}$

5-8 Pole figure for Ni50Ti50 shape memory alloy at $138^{\circ} \mathrm{C}$ shows a 110 texture

5-9 Two views of the compression load frame (constant load) mounted

on the X14A synchrotron beam line goniometer....

5-10 (left) Sangil Han of Georgia Tech, mounting his ring sample to the PANalytical

X-ray Diffractometer and (right) retained Austenite as a function of tool

flank wear

5-11 Diagram of the crack growth rate vs stress intensity range.

5-12 Neutron strain mapping results for the five samples subjected to cyclic fatigue 45

5-13 As-cast cylinder liner tube on NRSF2 for stress mapping ............................... 46

5-14 Through-thickness residual stress results from as-cast cylinder liner tubes.

5.15 Through-thickness Fe (211) d-spacing in the machined cylinder liner at locations with and without machined threads

5-16 Cross section of cruciform part (left)

5-17 Strains in three orthogonal directions for: (a) conventional welding wire,

(b) LTTW 1 wire, and (c) LTTW 3 wire

5-18 Neutron residual stress results for direction 1 for the three weld processes ......

6-1 Bill Charron (Ford) looking at laser welds at the Chicago Assembly Plant.....

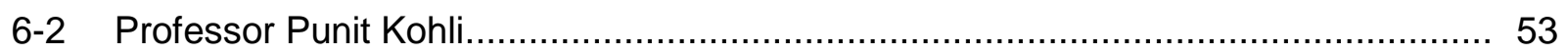

6-3 Vehicles produced at the Ford Chicago Assembly Plant ................................ 54

6-4 Dr. J. Yang, a GM researcher, visited HTML to test thermoelectric materials

for GM light trucks

6-5 W. Chi and Yang Tan, researchers from the State University of New York at Stony Brook 



\section{ACRONYMS AND ABBREVIATIONS}

\begin{tabular}{|c|c|}
\hline ACEM & aberration-corrected electron microscope \\
\hline ACR & Advanced Ceramic Research, Inc. \\
\hline AEM & analytical electron microscope \\
\hline AFM & atomic force microscope \\
\hline AML & Advanced Microscopy Laboratory \\
\hline ASTM & American Society for Testing and Materials \\
\hline BNL & Brookhaven National Laboratory \\
\hline CEOS & Corrected Electron Optical Systems \\
\hline CNC & computerized numerical control \\
\hline CRADA & cooperative research and development agreement \\
\hline CRCT & composite-reinforced ceramic technology \\
\hline DARPA & Defense Advanced Research Projects Agency \\
\hline DOE & U.S. Department of Energy \\
\hline DOE-ER & U.S. Department of Energy Office of Energy Research \\
\hline DSC & differential scanning calorimetry \\
\hline DUC & Diffraction User Center \\
\hline ECAP & equal channel angular processing \\
\hline EDS & energy-dispersive spectrometer \\
\hline EERE & DOE Office of Energy Efficiency and Renewable Energy \\
\hline EGR & exhaust gas recirculation \\
\hline ELSAM & Ernst Leitz Scanning Acoustic Microprobe \\
\hline EMS & Engineered Materials Solutions \\
\hline FEG & field-emission gun \\
\hline FIB & focused ion beam \\
\hline FSW & friction-stir welding \\
\hline FWHM & full width at half maximum \\
\hline FWMUC & Friction, Wear, and Machinability User Center \\
\hline GM & General Motors \\
\hline HFIR & High Flux Isotope Reactor \\
\hline HTML & High Temperature Materials Laboratory \\
\hline HTXRD & high-temperature X-ray diffraction \\
\hline IR & infrared \\
\hline LANSCE & Los Alamos Neutron Science Center \\
\hline LDRD & Laboratory Directed Research and Development \\
\hline LLNL & Lawrence Livermore National Laboratory \\
\hline MAUC & Materials Analysis User Center \\
\hline MBE & molecular beam epitaxy \\
\hline MCAUC & Mechanical Characterization and Analysis User Center \\
\hline MIT & Massachusetts Institute of Technology \\
\hline MITUC & Machining, Inspection, and Tribology User Center \\
\hline MRI & Major Research Instrumentation \\
\hline NASA & National Aeronautics and Space Administration \\
\hline NCNR & NIST Center for Neutron Research \\
\hline NDE & nondestructive evaluation \\
\hline NIST & National Institute of Standards and Technology \\
\hline NRL & Naval Research Laboratory \\
\hline NRSF & Neutron Residual Stress Mapping Facility \\
\hline
\end{tabular}




$\begin{array}{ll}\text { NSC } & \text { National Semiconductor } \\ \text { NSF } & \text { National Science Foundation } \\ \text { NSLS } & \text { National Synchrotron Light Source } \\ \text { OFCVT } & \text { Office of FreedomCAR and Vehicle Technologies } \\ \text { ORNL } & \text { Oak Ridge National Laboratory } \\ \text { PTS } & \text { powder-texture-stress } \\ \text { QSS } & \text { quasi-steady state } \\ \text { RSUC } & \text { Residual Stress User Center } \\ \text { SAcM } & \text { scanning acoustic microscope } \\ \text { SAM } & \text { scanning Auger microanalysis } \\ \text { SAN } & \text { scanning auger nanoprobe } \\ \text { SBIR } & \text { Small Business Innovative Research } \\ \text { SEM } & \text { scanning electron microscope } \\ \text { SMA } & \text { shape memory alloy } \\ \text { SNS } & \text { Spallation Neutron Source } \\ \text { SOFC } & \text { solid oxide fuel cell } \\ \text { STEM } & \text { scanning transmission electron microscope } \\ \text { SURA } & \text { Southeastern University Research Association } \\ \text { SWCNT } & \text { single-walled carbon nanotubes } \\ \text { TBC } & \text { thermal barrier coating } \\ \text { TEM } & \text { transmission electron microscopy } \\ \text { TMS } & \text { The Metallurgical Society, Inc. } \\ \text { TTPUC } & \text { Thermography and Thermophysical Properties User Center } \\ \text { UAB } & \text { University of Alabama, Birmingham } \\ \text { UHTC } & \text { ultrahigh-temperature ceramic } \\ \text { UT } & \text { University of Tennessee } \\ \text { UTK } & \text { University of Tennessee, Knoxville } \\ \text { XRD } & \text { X-ray diffraction } \\ \text { YSZ } & \text { yttria-stabilized zirconia } \\ & \end{array}$




\section{ADVANCED MATERIALS CHARACTERIZATION AT THE HIGH TEMPERATURE MATERIALS LABORATORY}

\section{Arvid E. Pasto, Director}

\section{The Facility}

The High Temperature Materials Laboratory (HTML) is a national user facility designed to support the development of advanced materials. It is sponsored by the U.S. Department of Energy (DOE) Office of Transportation Technologies in the Office of Energy Efficiency and Renewable Energy.

HTML provides researchers from U.S. industries, universities, and governmental agencies with handson access to a skilled staff and to a number of sophisticated, often oneof-a-kind devices for materials characterization. Located at Oak Ridge National Laboratory (ORNL), the $64,500-\mathrm{ft}^{2}$ building houses six

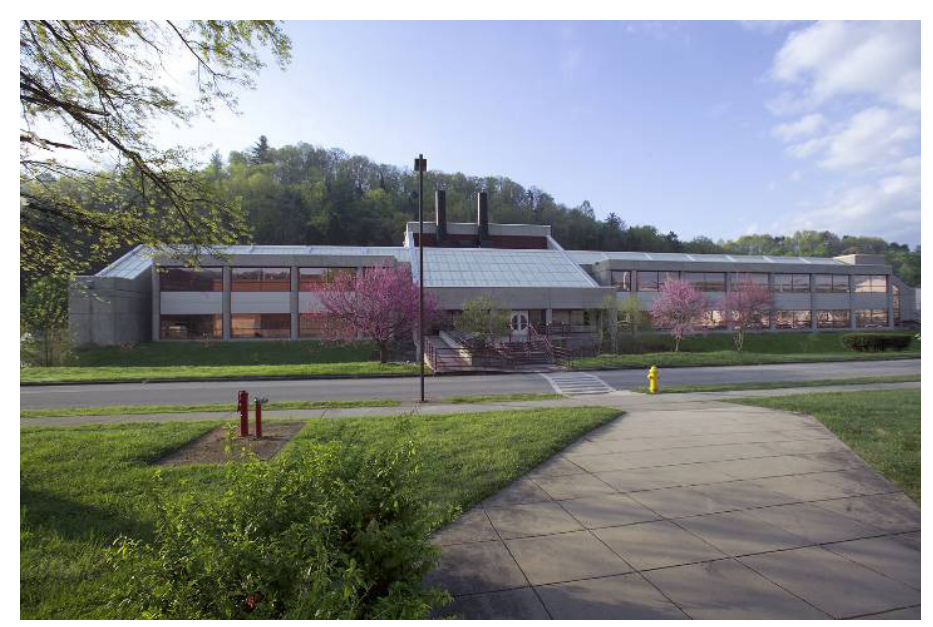

The High Temperature Materials Laboratory has been supporting the development of advanced materials since the mid-1980s.

"user centers," which are clusters of specialized equipment designed for specific types of properties measurements. The HTML also has a neutron beamline facility at the High Flux Isotope Reactor (HFIR) at ORNL and a synchrotron beamline at the National Synchrotron Light Source (NSLS) at Brookhaven National Laboratory.

HTML was conceived and built in the mid-1980s in response to the oil embargoes of the 1970s. The concept was to build a facility that would allow direct work with American industry, academia, and government laboratories in providing advanced high-temperature materials such as structural ceramics for energy-efficient engines. HTML's scope of work has since expanded to include other, non-high-temperature materials of interest to transportation and other industries.

\section{The User Centers}

\section{Materials Analysis User Center (MAUC)}

MAUC researchers employ electron microscopy and surface chemical analysis to determine structure, surface chemistry, and microstructure to the atomic level. Advanced microscopy capabilities allow rapid, direct elemental analysis of grain boundaries in metals and ceramics. Auger spectroscopy is available for analyzing material surfaces.

\section{Friction, Wear, and Machinability User Center (FWMUC)}

FWMUC employs instrumented machine tools to investigate machining processes as applied to hard materials such as ceramics and special alloys. Special emphasis is given to grinding processes. These dynamometer-equipped machines provide unique capabilities for studying 
grinding and machining parameters and their roles in controlling the topography and mechanical and wear properties of the resulting surfaces.

Inspection capabilities include a high-frequency scanning acoustic microscope, a multisensor coordinate measuring machine, instruments for measuring surface texture and topography, and instruments for determining the dimensional form of axially symmetric objects (e.g., circularity, cylindricity, and concentricity). In addition, FWMUC contains numerous specialized instruments for measuring friction and wear, including fretting, rolling, and sliding.

\section{Mechanical Characterization and Analysis User Center (MCAUC)}

MCAUC researchers study fracture toughness, tensile strength, flexure strength, and tensile creep of advanced materials at temperatures to $1500^{\circ} \mathrm{C}$ in air or controlled atmospheres. Special instrumentation is available for studying fiber-matrix interactions in both metal and ceramic matrix composites.

\section{Diffraction User Center (DUC)}

DUC has both room-temperature and furnace-equipped X-ray and neutron diffractometers. The $X$-ray furnace is used to study material properties at temperatures up to $2700^{\circ} \mathrm{C}$ in vacuum and up to $1500^{\circ} \mathrm{C}$ in air. DUC users have access to the NSLS at Brookhaven National Laboratory.

\section{Residual Stress User Center (RSUC)}

RSUC has two principal areas of expertise: X-ray diffraction and neutron diffraction. Its $X$-ray facility includes X-ray diffractometers to measure residual stress and texture in and near the surface of ceramics and alloys. Two systems provide highly flexible sample-tilt systems and either a divergent or a parallel beam.

Users can also access the NSLS, located at Brookhaven National Laboratory, through RSUC. HTML maintains a beamline at Brookhaven with structure and residual stress analysis capability.

The neutron residual stress facility, located at the HFIR, includes a special neutron spectrometer for rapid data collection, plus computer capabilities for data analysis. The spectrometer instrumentation allows researchers to quickly measure and map the stress fields inside relatively large solid objects.

\section{Thermography and Thermophysical Properties User Center (TTPUC)}

TTPUC researchers study thermal stability, expansion, and thermal conductivity of materials to $1400^{\circ} \mathrm{C}$. A laser flash instrument measures thermal diffusivity to temperatures of $1900^{\circ} \mathrm{C}$. The center also possesses a high-speed, high-sensitivity infrared camera for capturing thermal events digitally, allowing on-line or postoperation measurement of temperatures during rapid transient events.

\section{The Programs}

Within HTML are programs that function to help outside researchers use state-of-the-art characterization instrumentation to solve materials problems. In the HTML User Program, either nonproprietary or proprietary research can be performed. The former is provided free of charge if the user publishes the information produced; the latter requires payment.

Nonproprietary research projects typically last from a few days to 2 weeks at HTML. The major proviso is that the results must be submitted for publication within 6 months after completion of the research. 
For proprietary research, the user and HTML staff estimate the amount of HTML staff time required to complete the work. The user agrees to pay for this time at an hourly rate specified by DOE before research begins. These projects typically are more extensive than nonproprietary projects, and the user owns the research data.

Work is performed for other branches of DOE via direct funding or through cooperative research and development agreements (CRADAs), which typically consist of a cost-sharing arrangement between HTML and the outside organization but can also include $100 \%$ funds-in work. HTML can also characterize materials for another organization on a noncompetitive, full-cost-recovery basis under a Work for Others agreement.

Most, but not all, projects involve materials primarily related to the transportation industry. Ceramics, metal- and ceramic-matrix composites, lightweight materials such as aluminum and magnesium alloys, steels, and electronic materials have all been characterized at HTML. 



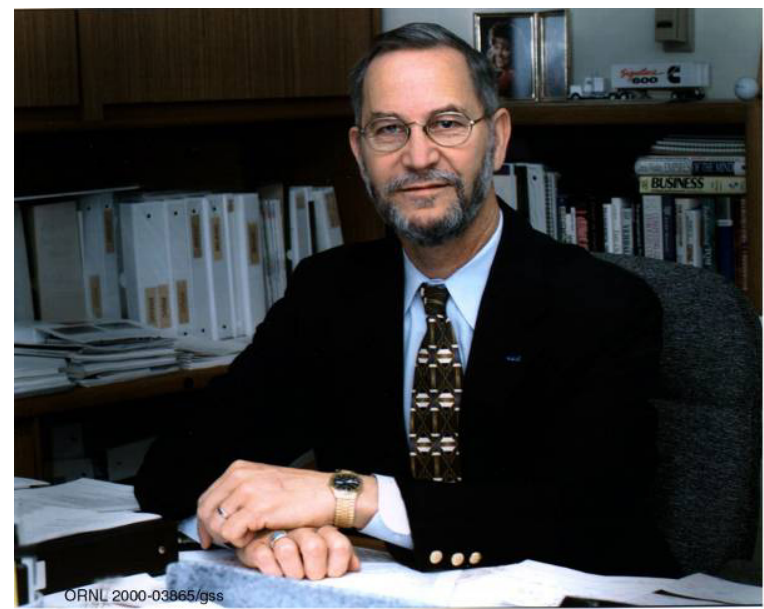

Dr. Arvid Pasto is the director of the HTML. He holds a Ph.D. in ceramics from the New York State College of Ceramics at Alfred University.
The HTML User Program continued to work with industrial, academic, and governmental users this year, accepting a record number (110) of new projects and developing 33 new user agreements. Table 1 presents the breakdown of these statistics.

Figure 1 depicts the continued growth in user agreements and user projects. The total number of HTML proposals has now exceeded 1450. Also, the number of new agreements bodes well for the future. At the end of this report is a list of proposals to the HTML and a list of agreements between HTML and universities and industries, broken down by state.

Table 1. Statistics of HTML operations for FY 2001-FY 2005 (showing user proposals and user agreements)

\begin{tabular}{ccccc|cccc}
\hline \multirow{2}{*}{ FY } & \multicolumn{5}{c|}{ New proposals } & \multicolumn{4}{c}{ Cumulative proposals } \\
\cline { 2 - 8 } & Total & Industrial & Academic & Other & Total & Industrial & Academic & Other \\
\hline 2001 & 92 & 33 & 48 & 11 & 1084 & 452 & 593 & 39 \\
2002 & 97 & 35 & 56 & 6 & 1181 & 487 & 649 & 45 \\
2003 & 72 & 27 & 44 & 1 & 1253 & 514 & 693 & 46 \\
2004 & 87 & 28 & 54 & 5 & 1340 & 542 & 747 & 51 \\
2005 & 110 & 56 & 52 & 2 & 1450 & 598 & 799 & 53 \\
\hline \multicolumn{8}{c}{ New agreements } & \multicolumn{5}{c}{ Cumulative agreements } \\
\hline \multicolumn{1}{c}{ Total } & Industrial & Academic & Other & Total & Industrial & Academic & Other \\
\hline 2001 & 48 & 32 & 15 & 1 & 579 & 353 & 205 & 21 \\
2002 & 63 & 5 & 56 & 2 & 642 & 358 & 261 & 23 \\
2003 & 50 & 44 & 4 & 2 & 692 & 401 & 265 & 25 \\
2004 & 53 & 47 & 5 & 1 & 745 & 449 & 270 & 26 \\
2005 & 33 & 27 & 6 & 0 & 778 & 476 & 276 & 26 \\
\hline
\end{tabular}

Program highlights this year included several outstanding user projects (some of which are highlighted in later sections), the annual meeting of the HTML Programs Guidance and Evaluation Panel, and continued progress in equipment and facilities development. For instance, this year beneficial operation of the aberration-corrected electron microscope (ACEM) was initiated.

Also, the upgraded neutron residual stress beamline (NRSF2) on the HFIR was made operational on user projects, including one featuring Caterpillar. The beamline possesses a much-improved full width at half maximum (FWHM) peak performance (about one-third narrower than previously) and a factor-of-ten improvement in peak intensity. The beamline now has much 
improved capability because of improvements made to the reactor itself, the beamline, and the diffraction instruments.

Funding was received this year for HTML's participation in construction and operation of the VULCAN beamline at the Spallation Neutron Source (SNS). The SNS, an extremely high flux pulsed neutron source, is in the final stages of construction at ORNL, and the VULCAN beamline is to be the "materials" diffractometer. Our funding will provide for development of an off-line specimen alignment system, which will allow users to have their experiment all set up at an off-line location, so that when their project time begins, they can put the specimen on the beam and begin taking data instantly. This will save much precious beamline time. Our funding also will purchase extra detectors, further increasing VULCAN's coverage and speed. The funding will also provide for staff time for VULCAN operations.

Several other improvements in capability, facilities, and equipment have occurred, and some new staff have been added. Please see the following sections for details.

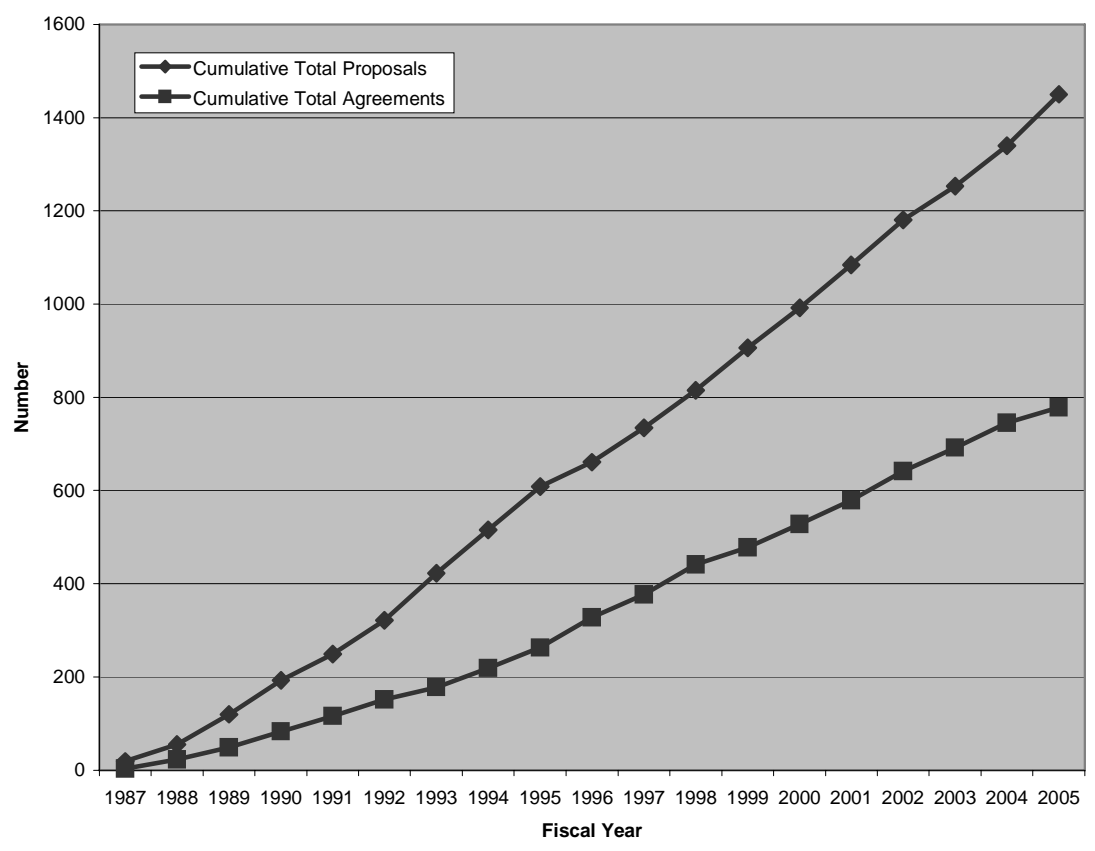

Fig. 1. Plot showing HTML User Program growth through user agreements and user proposals. 


\section{User Center Members \\ Larry Allard, Leader \\ Carolyn Wells, Secretary}

\author{
David Joy \\ Harry Meyer \\ Karren More \\ Larry Walker
}

The Materials Analysis User Center (MAUC) provides world-class facilities and a staff of technical experts for characterizing the structure and chemistry of advanced materials. We emphasize using these tools to relate microstructure to materials performance. The MAUC comprises a suite of laboratories that contain the latest-generation electron microscopes and surface analysis instruments, all of which are available to visiting researchers. Research specialties include characterization of nanophase materials such as catalysts, fullerenes (carbon nanotubes), and nanoparticulates; structural ceramics; precipitation phenomena in alloy systems; electron holography (e.g., for determining nanoparticle shapes); and characterization of multilayer surface films.

\section{MAUC Instruments}

- Hitachi S-4700 field-emission gun (FEG) scanning electron microscope (SEM) with energydispersive spectrometer (EDS)

- Hitachi S-3400 environmental SEM with EDS

- Hitachi HF-2000 FEG analytical electron microscope (AEM)

- Hitachi HD-2000 FEG scanning transmission electron microscope (STEM)

- JEOL 8200 electron microprobe with five wavelength-dispersive X-ray spectrometers

- PHI 680 scanning auger nanoprobe (SAN)

- Hitachi FB-2000 focused ion beam (FIB) micromill with microsampling capability

- JEOL 2200FS-AC aberration-corrected STEM/TEM (ACEM)

- Leica UCT ultramicrotome with cryosectioning capability

\section{MAUC News}

\section{ACEM Results Win Physical Sciences Poster Contest at Annual Microscopy Society Meeting in Honolulu}

A poster showing imaging of catalyst clusters taken using HTML's ACEM (manufactured by JEOL Ltd., Akishima, Japan) was awarded First Prize in the Physical Sciences division of the Microscopy Society of America's annual poster contest (Fig. 1-1). The poster was the only one selected on every judge's ballot, from among the more than 200 competitors. The poster, entitled "Alumina-supported Metal Clusters Revealed by Aberration-Corrected Electron Microscopy," described research with Prof. Bruce Gates and graduate student V. Bhirud at the University of California-Davis. The research was funded by an Office of FreedomCAR and Vehicle Technologies (OFCVT) subcontract on the "Catalysis by Design" project and was conducted with ORNL postdoctoral scholar Melanie Moses; her ORNL associates, Chaitanya Narula, Douglas Blom, and Larry Allard; and JEOL engineers T. Aoki and S. Mishina. The poster showed clear imaging of three-atom clusters of rhenium carbonyl as well as single atoms 


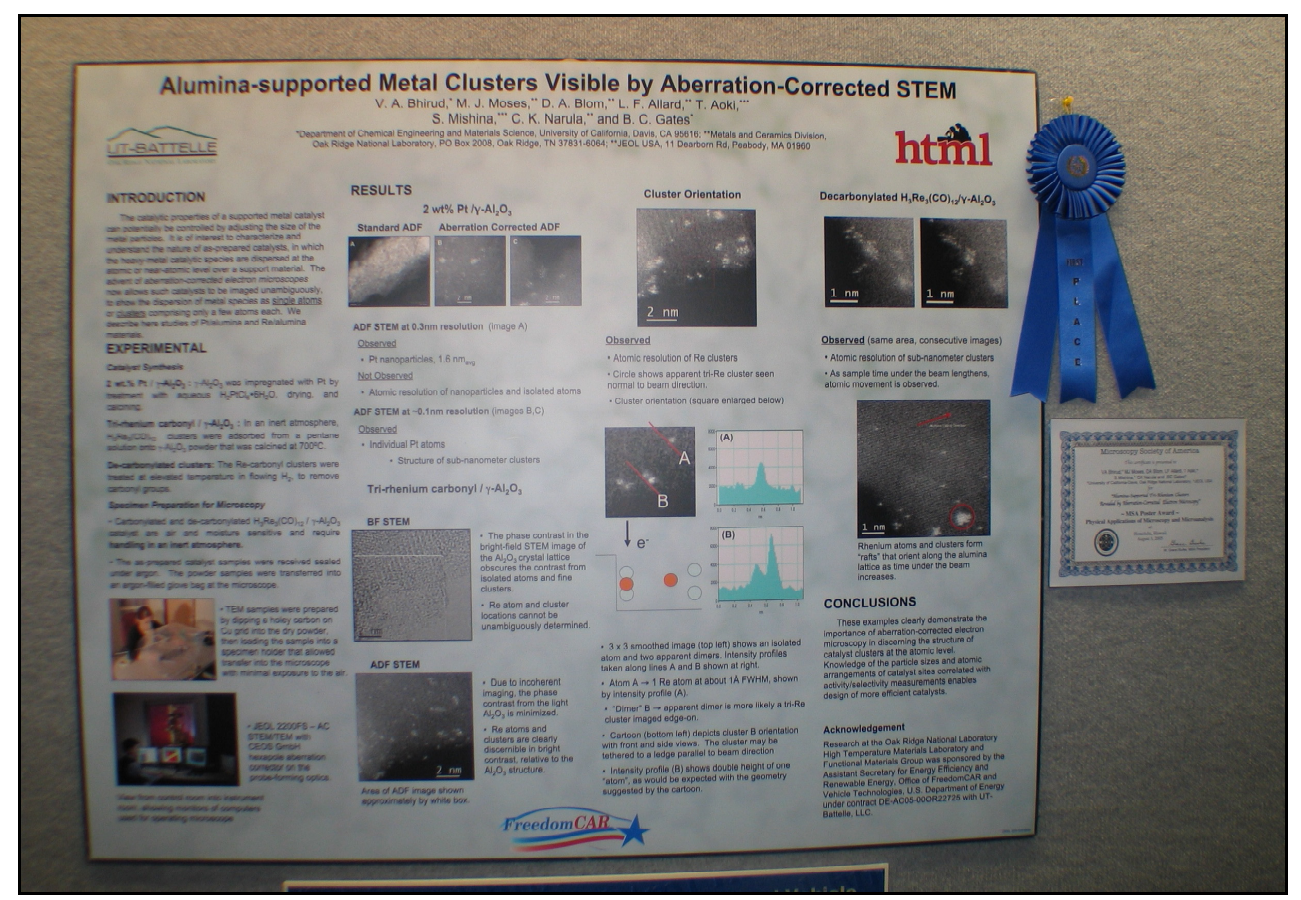

Fig. 1-1. First-prize poster in Microscopy Society of America Physical Sciences Division poster contest, 2005.

and dimers, consistent with the results of spectroscopic characterization of the samples at the University of California-Davis. The new JEOL 2200FS ACEM provided the high-resolution dark-field images to allow the clusters to be unambiguously analyzed (Fig. 1-2). This illustrates the value of our new instrument for producing high-quality research results that are of great interest in the scientific community.

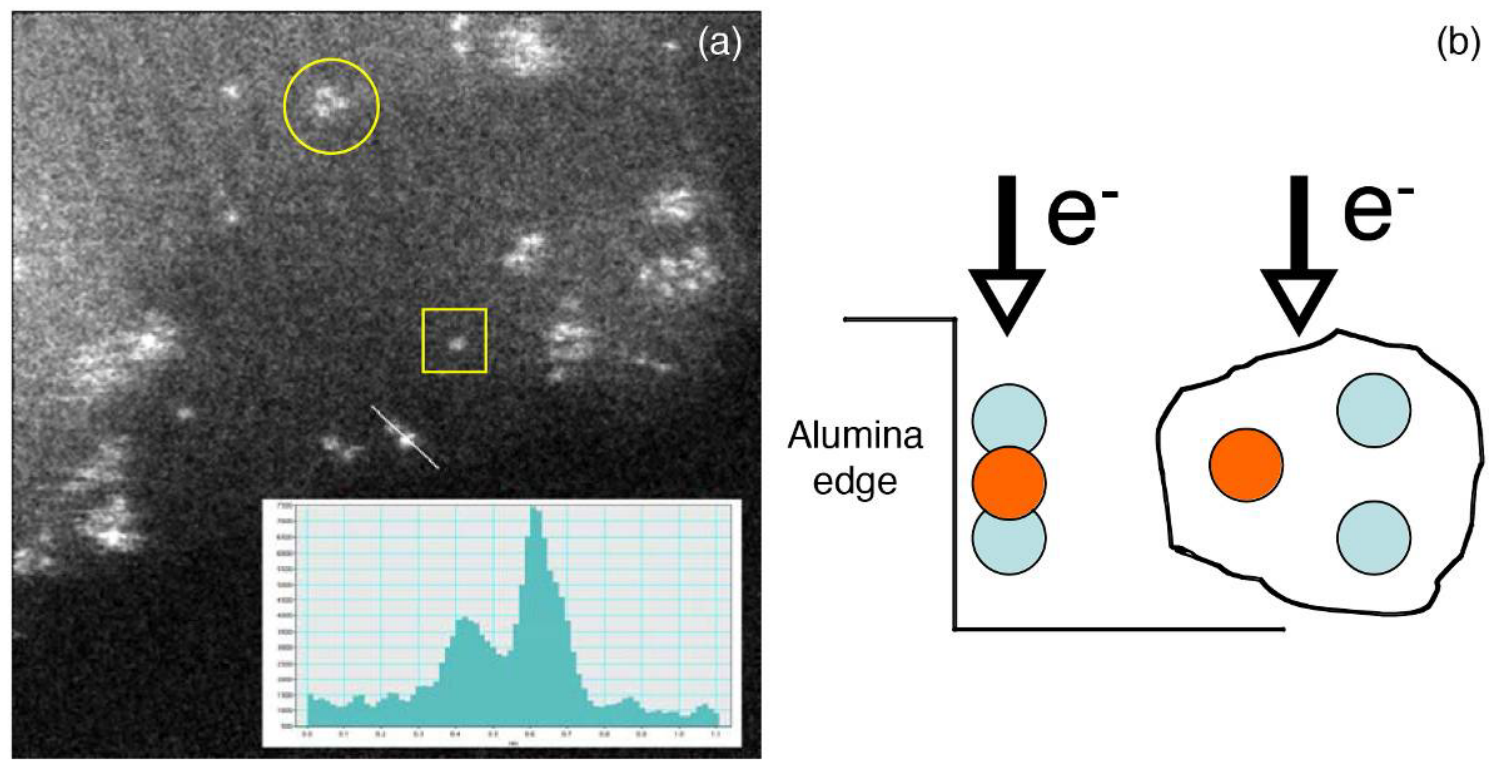

Fig. 1-2. (a) Dark-field image of tri-rhenium clusters on alumina. Three-atom cluster shown circled. Single atom shown in square. Apparent 2-atom cluster (arrowed) shows intensity profile inset. Brighter atom has double the intensity of dimmer atom, suggesting the drawing in (b). The three-atom cluster is edge-on to beam. 


\section{Selected Highlights}

\section{Imaging of Oxygen Atomic Columns in Perovskite Materials}

HTML: Dr. Douglas Blom and Dr. Larry Allard

JEOL USA: Mr. Satoshi Mishina

The ability of the ACEM (Fig. 1-3) to image very light elements such as oxygen in crystalline structures was demonstrated in a study of strontium titanate, a material with the perovskite structure, which is shown in the drawing in Fig. 1-3. The dark-field image shows the structure of the cubic material looking down a cube edge, so that in the annular dark-field image the heavier $\mathrm{Sr}$ atoms are brightest, the medium $\mathrm{Ti}$ atoms are dimmer, and the light $\mathrm{O}$ atoms are dimmest, but still clearly visible. An intensity profile over a row of $\mathrm{Ti}$ and $\mathrm{O}$ atoms shows the oxygen column intensity clearly resolved from the titanium column intensity. It requires sub-Ångström resolution to achieve this demonstrated imaging capability. It is of importance to be able to record images such as this in studies of technologically strategic materials like thermoelectrics, photovoltaics, and oxide-supported catalysts.
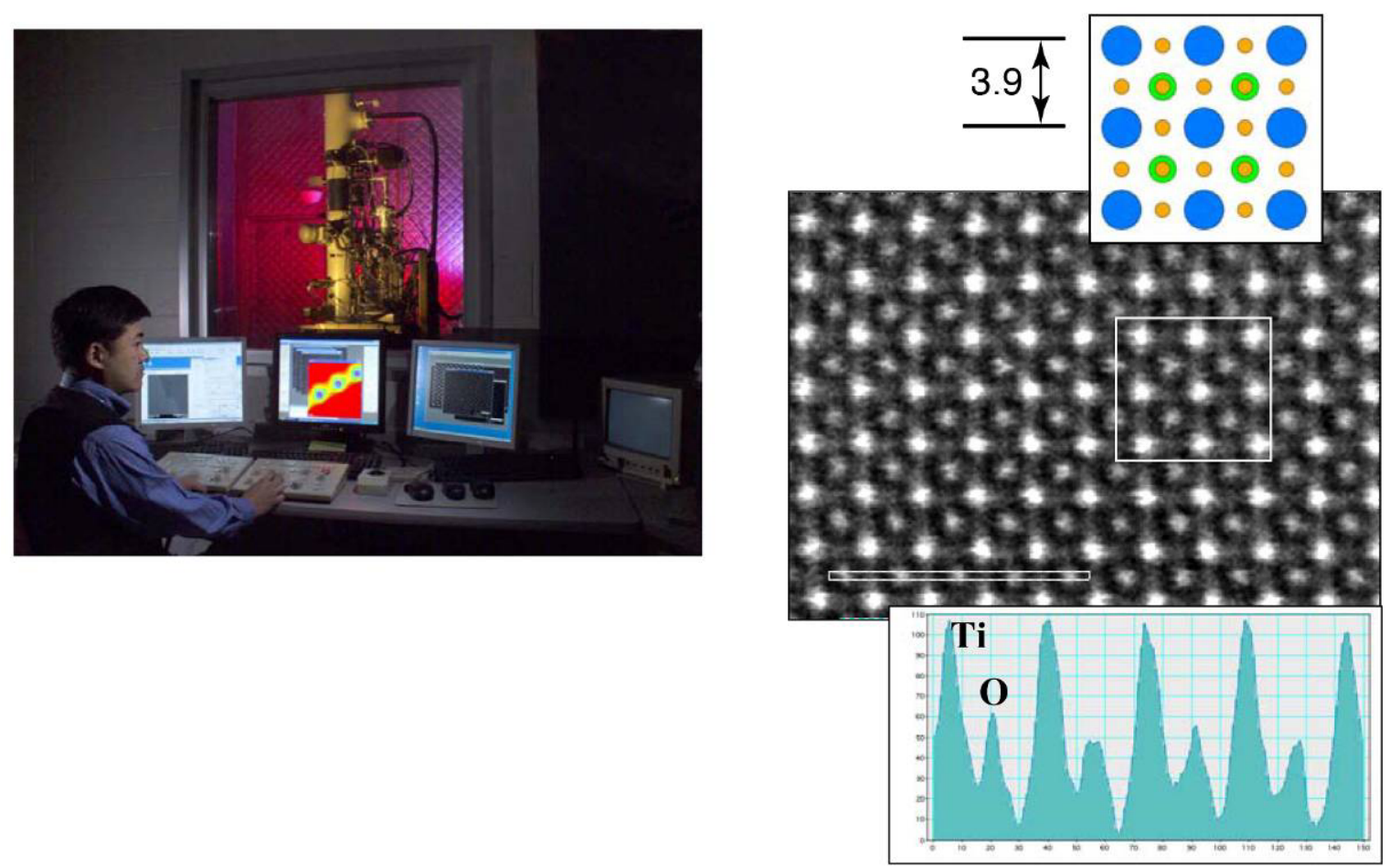

Fig. 1-3. ACEM as seen from the control room. The dark-field image is of SrTiO3, looking down a cube edge $(<100>$ orientation). The drawing indicates individual columns of oxygen $(\mathrm{O}$, orange) between columns of strontium ( $\mathrm{Sr}$, blue) and titanium ( $\mathrm{Ti}$, green) The intensity profile graph shows clear resolution of oxygen columns in the Ti-O row.

\section{Structure and Morphology of a Uniform-Sized Nanoscale Bimetallic Catalyst}

University Collaborators: Dongxia Liu and Hong Xie

HTML: Dr. Jane Howe

Dr. Jane Y. Howe has been working with Dongxia Liu and Hong Xie, two Ph.D. students from Prof. Chris Williams's group at the Department of Chemical Engineering, University of South Carolina-Columbia on the structure and morphology of uniform-sized nanoscale bimetallic 
catalysts. The project is a CNMS/HTML joint proposal. The bimetallic catalysts prepared via the dendrimer-templating method, have been carried out on a Hitachi HF-2000 field emission TEM. There are several advantages in the dendrimer-templating method. It gives better control on the size and composition. It is capable of producing bimetallic nanoparticles that provides tailored catalyst properties, activity, and selectivity. The dendrimer morphology prevents the nano-sized particles from agglomeration and provides means to immobilize catalyst on the support. The micrograph in Fig. 1-4 shows Pt-Cu bimetallic catalyst particles supported on silica. As indicated in the histogram, the particle size mean is $4.1 \mathrm{~nm}$ with reasonably uniform size. EDS was used to determine the chemical composition of the particles. A simulation of $1: 1 \mathrm{Pt} / \mathrm{Cu}$ atomic ratio composition matched the experimental data (see Fig. 1-5).
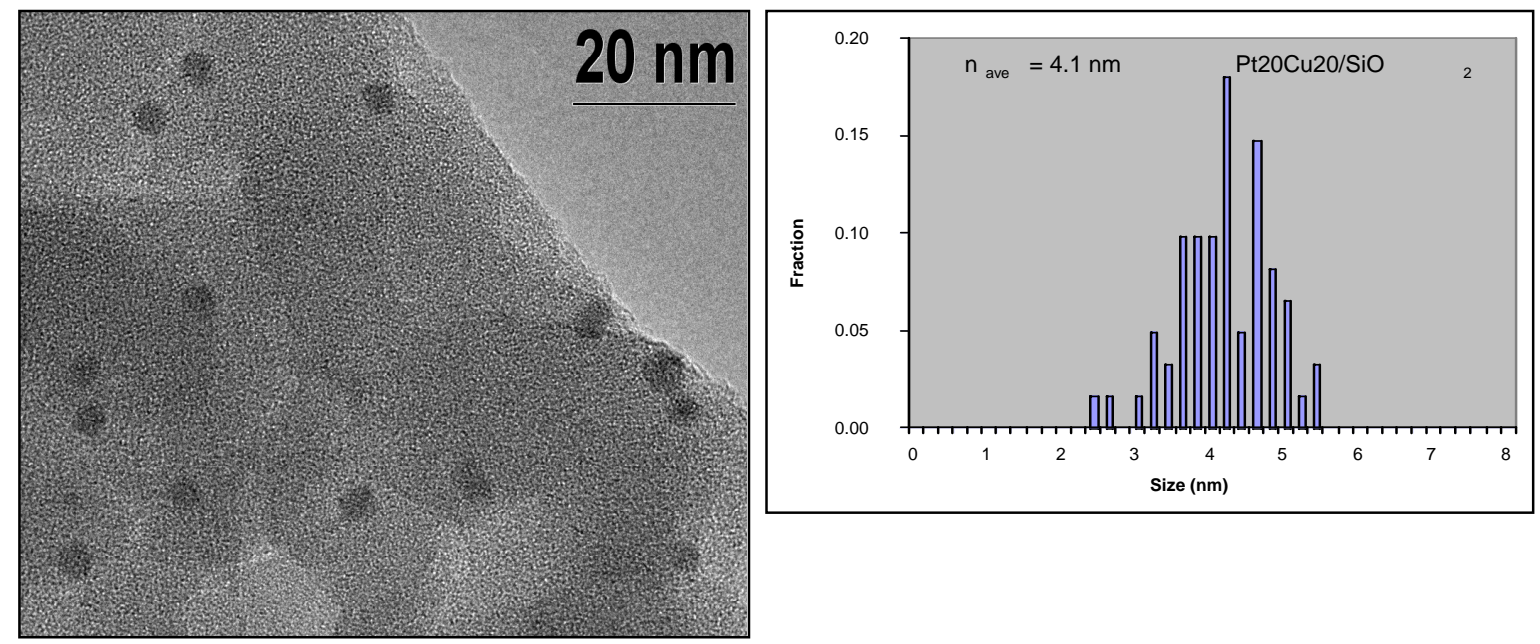

Fig. 1-4. (left) Pt-Cu bimetallic catalyst particles on $\mathrm{SiO}_{2}$. Typical particles have a 1:1 ratio of $\mathrm{Pt}$ to $\mathrm{Cu}$. (right) The size range is sharply peaked at about $4 \mathrm{~nm}$.

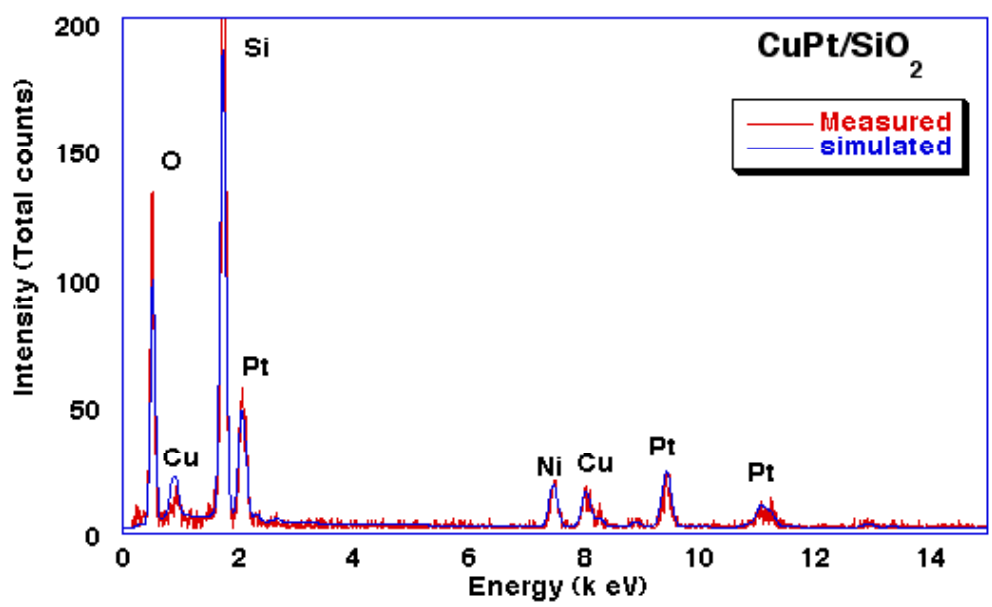

Fig. 1-5. EDS spectra (overlapped) of the Pt-Cu catalyst, computed at a 1:1 atomic ratio. There is a good agreement between the experimental and computed intensities for Pt and $\mathrm{Cu}$ at this ratio. 


\title{
Scanning Auger Microscopy of Alkylated Crystalline Silicon(111) Surfaces
}

\author{
University Collaborator: Prof. Nathan Lewis
}

HTML: Dr. Harry Meyer

Silicon materials used in solar energy conversion devices must be prepared to a high degree of purity in order to prevent recombination of the photoexcited electron-hole pair. This materialsprocessing requirement makes silicon-based solar energy devices prohibitively expensive for most commercial applications, thus limiting the use of this important renewable energy source. One deleterious process that must be prevented on solar energy cells is silicon oxidation in ambient environments. This has traditionally been done by covering the silicon surface in a thick, thermally grown insulating layer, also adding to the material processing and cost. A significant impact on the cost of this important technology may be realized simply by replacing the silicon insulating layer with simple organic functional groups that are easy to prepare using wet-chemical techniques.

Surface passivation chemistry was the focus of the study performed at the HTML. Prof. Nathan Lewis and his group at the California Institute of Technology have developed a wet-chemical alkylation technique that results in an atomically flat surface covered with bound alkyl groups that almost completely prevents formation of silicon oxides as the surface is exposed to oxidizing environments over long time periods. The HTML project attempted to chemically map the oxidation of alkylated Si surfaces to determine whether it was proceeding uniformly or in discrete areas. Because auger spectroscopy is able to distinguish silicon from silicon dioxide, Dr. Harry Meyer was able to construct a surface map of the growth of silicon dioxide as a function of surface morphology. Figure 1-6 shows a set of images obtained on a $\mathrm{C}_{2} \mathrm{H}_{5^{-}}$ terminated $\mathrm{Si}(111)$ surface exposed to air for 8 days. The upper left panel shows a silicon map of $\mathrm{a} \sim 1 \mathrm{~mm}^{2}$ area of the surface; the upper right panel is an oxygen map of the same area. The lower left panel is a composite image of the overlaid maps of the Si (red) and O (blue) regions. The final panel is the normal SEM image. The results suggest that on the passivated surface, the detectible oxide is not growing in a uniform manner, but rather in small patches, leaving large portions of the alkylated surface free of any oxide.

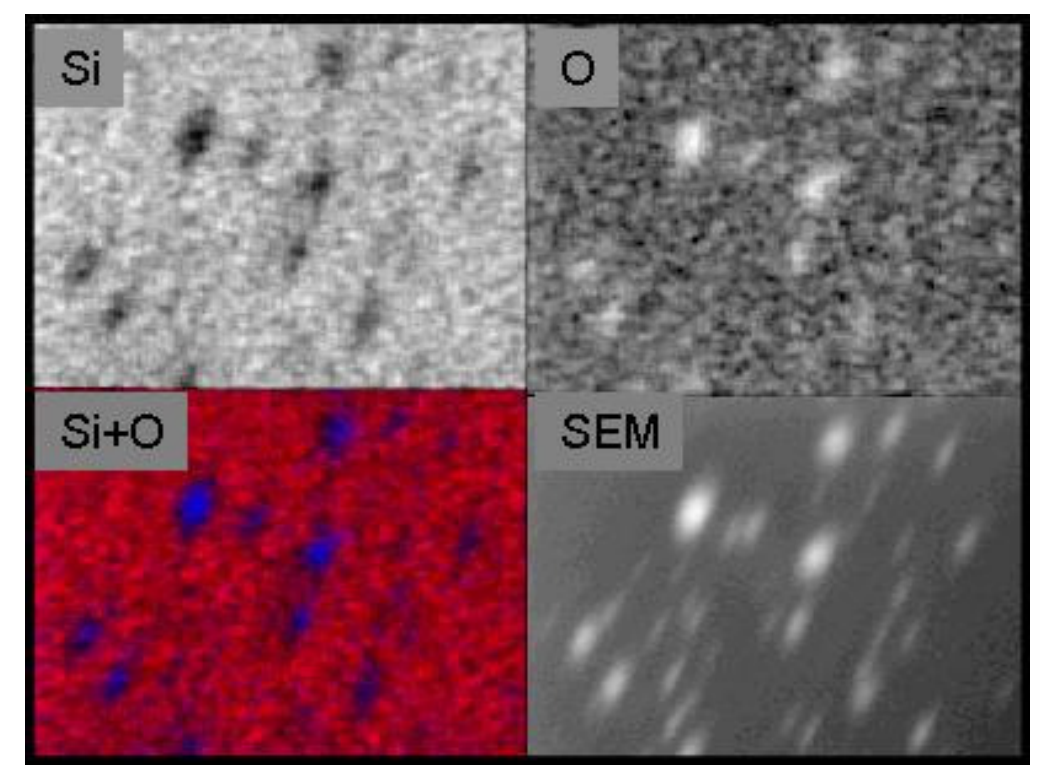

Fig. 1-6. Scanning auger elemental maps for Si and $\mathrm{O}$ (upper left and right, respectively), an overlay of both (lower left), and a secondary electron (SEM) image (lower right). 



\author{
User Center Members \\ Peter Blau, Leader \\ Christine Goudy, Secretary
}

\author{
Jun Qu \\ Randy Parten \\ Ronald Chand \\ Brian Jolly
}

\title{
MITUC Renamed FWMUC
}

During FY 2005, the Machining, Inspection, and Tribology User Center (MITUC) was renamed the Friction, Wear, and Machinability User Center (FWMUC) to better reflect its evolving scope and focus. The mission of FWMUC is to enable the selection and use of advanced materials and surface treatments by characterizing their frictional behavior, their durability under wearcausing conditions, and the nature of their response to machining processes, especially grinding. Precision measurement of surface features, subsurface damage, and micromechanical characteristics supports these research areas, which address a host of applications in transportation, energy, and industrial technologies.

The friction and wear characteristics of a material depend on its properties and the context of its use. It is therefore critical to select testing conditions that appropriately mimic those of the intended application. Similarly, when advanced materials are machined, they must be evaluated in the context of the machine tool characteristics; the processing conditions; and the suitability of tooling materials, coolants, and grinding media. The user center's new name clarifies the mission of the user center and reflects a broad scope of its activities, which spans from investigating a material's response to machining processes to characterizing the surface damage that signals the end of its wear life.

Highlights from selected FWMUC activities follow. They resulted in a series of presentations and publications on diverse subjects, ranging from the development of new abrasion testing standards for coated surfaces to the precision turning of ceramics.

\section{FWMUC Instruments}

\section{New Machine Tool Will Support Grinding Research}

A new Chevalier CNC surface grinder was obtained with HTML capital equipment funds and was installed in the FWMUC (Fig. 2-1). The new grinder will replace two

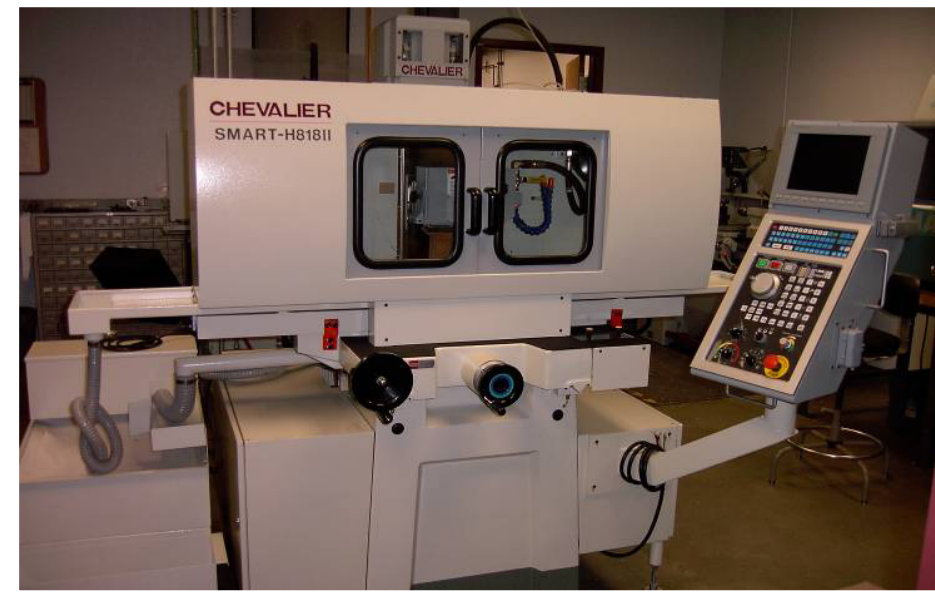

Fig. 2-1. A new Chevalier programmable surface grinder was purchased in FY 2005. 
aging Harig grinders that have been worn out from years of use on ceramics and other difficultto-machine advanced materials. Plans are to instrument the new machine similarly to the K.O. Lee creep-feed grinder so it can be used for grindability research. In addition, the new grinder will support specialized test specimen preparation needs of other user centers. FWMUC machining research technicians received thorough training on the new machine.

\section{Machining}

- Grindability testing system to characterize newly-developed ceramics

- ProLIGHT 3000 ${ }^{\mathrm{TM}}$ tabletop computerized numerical control (CNC) turning center

- Benchman® VMC4000 tabletop CNC vertical machining center

- Cincinnati Sabre multi-axis grinder

- Instrumented K. O. Lee creep-feed grinder

- Instrumented Weldon cylindrical grinder

- Precitech high-precision, single-point turning system

- Chevalier programmable surface grinder

\section{Measurements of Form, Roughness, and Subsurface Damage}

- EMD Legend coordinate measuring machine

- Mahr formtester

- Nikon optical comparator

- Rodenstock Model 600 laser surface profile-measuring system (non-contact)

- Taylor Hobson Talysurf 120 stylus surface-profile-measuring system (contact)

- Kræmer Scientific Instruments SAM2000 scanning acoustic microscope

- Nanoscience E-AFM atomic force microscope

Friction, Lubrication, and Wear Testing

- $\quad$ Plint Model TE-77 reciprocating sliding wear tester (ASTM G 133, G 181)

- Plint Model TE-53 multimode friction and wear tester

- Instrumented scratch tester for hardness (ASTM G 171) and adhesion testing

- High-temperature, pin-on-disk, friction and wear test system (to 1000 deg C)

- Knoop and Vickers microindentation hardness testing machine

- Loop abrasion testing machine (ASTM G 174)

- Elevated temperature, oscillating scuffing test system

- Pin-on-disk friction and wear testing stations (ASTM G 99)

- Repetitive impact testing system

- Sub-scale brake materials tester instrumented for friction and temperature

- Teledyne Taber portable scratch testing apparatus

- Hysitron Triboindenter ${ }^{\mathrm{TM}}$ for nanoscale micromechanical properties and abrasion

\section{New Method for Abrasion Testing}

HTML: Jun Qu, John Truhan, and Peter Blau

FWMUC staff members Jun Qu, John Truhan (University of Tennessee, Knoxville), and Peter Blau have developed a new method for abrasive wear testing by modifying the continuous-loop abrasion testing machine to hold cylindrical test specimens. The machine was originally designed to conduct American Society for Testing and Materials (ASTM) loop abrasion tests under standard G-174, which requires a flat, rectangular test specimen to be pressed against a moving abrasive belt running over a pulley wheel. However, many practical wear parts are cylindrically shaped. An example is the fuel injector plunger in a diesel engine. In order to 
provide FWMUC users with additional capabilities to evaluate the abrasion resistance of cylindrical components, a new low-load specimen holder for short cylinders was designed, and the wear calculations were modified accordingly. Validation tests were conducted on several alloys, ceramics, and cermets in order to confirm the usefulness of the new geometry. Results comparing flat with cylindrical abrasion geometries confirmed the usefulness of the new method. A description of the test, which is now available to HTML users, was published on line by ASTM's Journal of Testing and Evaluation.

\section{Selected Highlights}

\section{Two University Projects Investigate Single-Point Diamond Turning of Ceramics}

University Collaborators: John Patten and Biswarup Bhattaacharya, University of Western Michigan; Ravishankar Mariayyah, the University of North Carolina, Charlotte

\section{HTML: Jason Braden (former staff member)}

Two universities submitted successful user proposals to conduct research on precision diamond turning of ceramics. University of Western Michigan Prof. John Patten and Ph.D. student, Biswarup Bhattacharya, visited the HTML in October to conduct single-point diamond turning tests of SiC. Precision, single-point turning of $\mathrm{SiC}$ is an important technology for applications such as optical systems in satellites. Nominally brittle materials, such as semiconductors and ceramics, can often be deformed plastically if the scale of the deformation is small enough to avoid brittle fracture. Typically, the size scale for the ductile-to-brittle transition occurs in the range associated with nanotechnology applications. In the ductile regime, even these ceramic materials behave much like metals, to the extent that metal-like cutting "chips" are formed. Previous work by John Patten on single crystals of $\mathrm{SiC}$ indicated that changes in the crystalline structure can result in the material as a result of the shallow depths of cut used in ductile grinding.

The current work used the recently upgraded Precitech turning center to study the response of $\mathrm{SiC}$ to depths of cut on the order of a few tens of nanometers. Instrumented turning tests were coupled with the examination of cutting chips and turned surfaces by optical and scanning acoustic microscopy. The results provided a better understanding of the changes in material structure and properties that occur during precision turning of $\mathrm{SiC}$ ceramics.

In a related project, Ravishankar

Mariayyah, a Ph.D. student at the University of North Carolina, Charlotte, worked with Jason Braden of the FWMUC to study the process of single-point diamond turning of silicon nitride with nanometer-scale depths of cut. With such shallow precision-cutting depths, made possible with the FWMUC Precitech 2000 DTM, ceramics that usually machine in a brittle manner can be induced to form chips in a ductile mode, thereby improving the surface quality and reducing the incidence of subsurface fractures. The test specimens were thin discs of silicon nitride (Fig. 2-2). A video macro-camera system was used to observe chip formation at different cutting

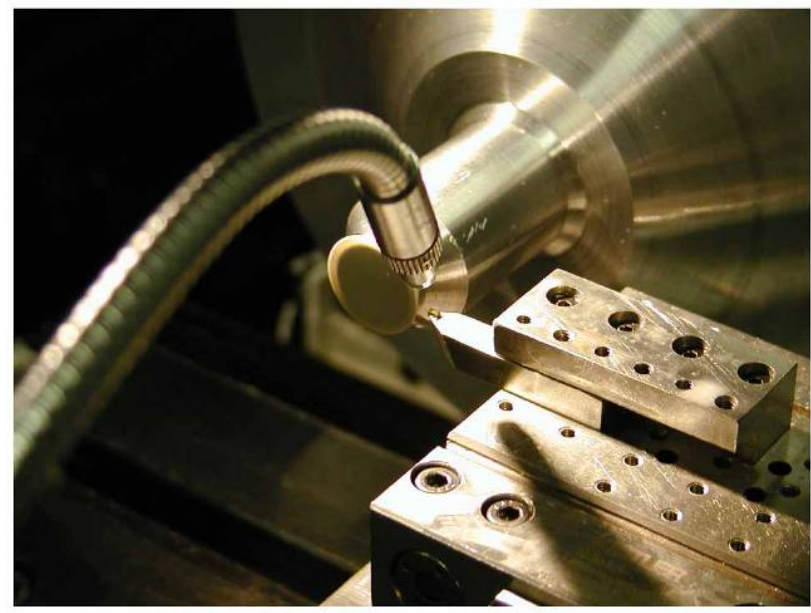

Fig. 2-2. Single-point turning of a silicon nitride disc on the Precitech 2000 DTM. 
speeds and depths of cut in the nanometer range. The diamond cutting tool edge was also photographed to estimate its wear rate and to better understand the mechanisms of attritious and microfracture-induced tool wear.

\section{Novel Coating Improves the Frictional Performance of Cast Amorphous Alloy} Industrial Collaborator: Tom Steffner

\section{HTML: Jun Qu and Peter Blau}

Amorphous metallic alloys have been of interest to the scientific and engineering materials community because they are said to offer certain advantages in strength and corrosion resistance over that of traditional metallic alloys. Applications such as dental root canal files have been proposed because the use of cast amorphous alloys has the potential to substantially reduce file cost. However, the higher than desirable friction coefficients of these materials against tooth enamel during drilling has been a problem for amorphous metal alloys because it generates too much heat.

A new class of friction-reducing treatments has been under development for several years at Better Than New LLC, in Chattanooga, Tennessee. This deposition process has a variety of potential applications, not only for dental tooling, but also for surgical instruments, industrial machinery, and engine components. Past research on these coatings under the HTML User Program has characterized the structure and composition of the treatment and has shown its ability to reduce frictional heating. The current user project was designed to better understand whether the coating could reduce the friction of amorphous alloys against simulated dental enamel.

FWMUC staff members Jun Qu and Peter Blau worked with Tom Steffner, president of Better than New LLC, to conduct the tests. Specimens in the form of small rods (dental files), were tested in reciprocating motion against a ceramic material (alumina) that simulated tooth enamel (Fig. 2-3). The amorphous alloy is primarily $\mathrm{Zr}$-Ti with minor alloying elements to enable it to remain glassy during casting. In addition, tests were run using $\mathrm{Ni}$ - Ti alloy rods of similar size to compare the test specimens with a commercially used dental material. Two sliding speeds were used to approximate the surface speed of typical dental root canal files during drilling procedures.

As shown in Fig. 2-4, the average friction coefficients in repeated tests of the Better Than New-treated amorphous alloy files were significantly lower than those for either a nontreated amorphous alloy or a Ni-Ti file material. This suggests that the Better than New dry-film coatings could enable the use of

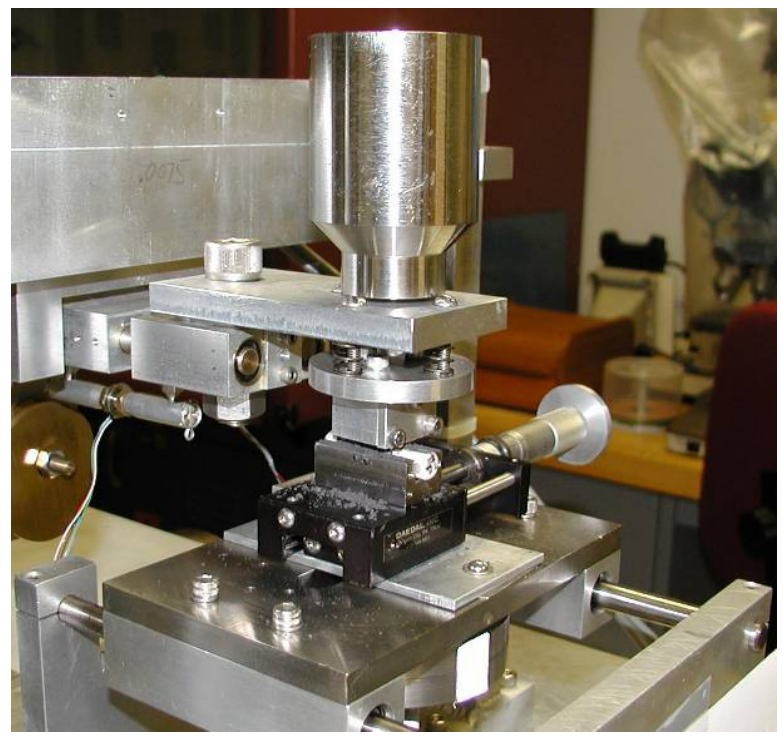

Fig. 2-3. A reciprocating friction and wear testing apparatus was modified to hold dental files. The lower stage reciprocates against the upper (fixed) specimen, which in the current instance, was a dental file blank mounted crossways to the direction of oscillation. cast amorphous alloys in friction-critical applications. The coating itself has received approval from the U.S. Food and Drug Administration, but clinical trials are needed to verify that the trends revealed in the current experiments will be repeated under the conditions of actual root 


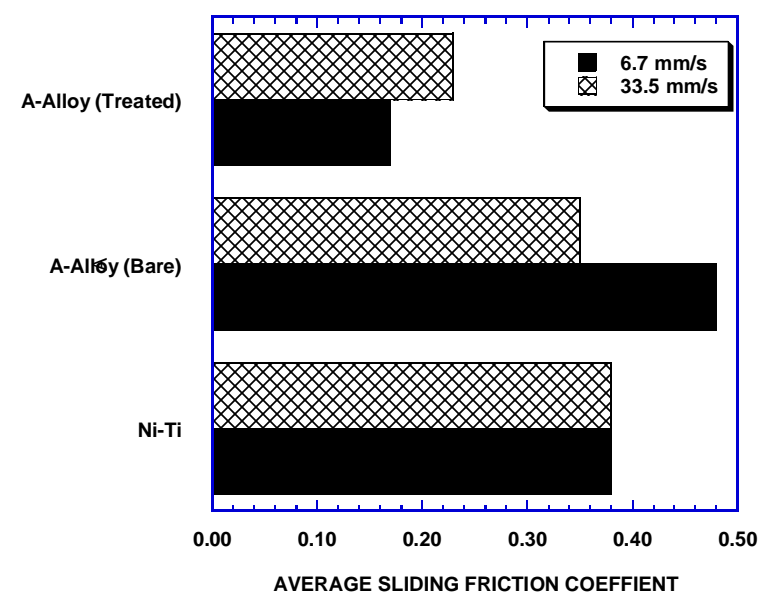

Fig. 2-4. The magnitude of the sliding friction coefficient, which relates to frictional heating, was reduced through the use of the novel Better than New treatment (upper bars). canal procedures. A publication authored by P. J. Blau, T. E. Steffner, and J. Qu was submitted to the Journal of Materials Science and Engineering.

FWMUC Collaborates with PNNL in Research on Fuel Injector Materials for Hydrogen Internal Combustion Engines

Laboratory Collaborator: James Holbery

HTML: Laura Riester and Peter Blau

The use of hydrogen to power internal combustion engines presents numerous challenges for materials technology. Working through the user program, James Holbery, a principal investigator from Pacific Northwest National Laboratory (PNNL), visited ORNL to conduct a series of microscratch studies on fuel injector surfaces that were exposed to hydrogen in PNNL's pressure chamber.

worked with Working with Laura Riester and Peter Blau, Holbery used the Hysitron Triboindenter ${ }^{\mathrm{TM}}$ to measure nanoscale indentation hardness, elastic modulus, and scratching characteristics within the bores of two kinds of commercially manufactured steel fuel injectors that had been exposed to hydrogen pressures of up to $4500 \mathrm{psi}$ at temperatures of about $100^{\circ} \mathrm{C}$. Exposure of one of the injector specimens resulted in the formation of Mo- and $\mathrm{W}$-containing crystallites on the surface that ranged in size from about $100 \mathrm{~nm}$ to about $5 \mathrm{~mm}$ in diameter and about $4 \mathrm{~mm}$ high. The crystallites tended to reduce the sliding friction of the diamond tip slightly, but in general, hydrogen exposure raised the friction coefficient with the indenter tip. This preliminary work revealed the presence of the new crystalline hydrides, demonstrated that with care the tribological properties of actual fuel injector components could be characterized on the micro to nano scale, and established specimen handling and testing procedures for future studies of injector materials and components. Results raised a number of important research questions for the application of conventional and emerging materials in hydrogen-powered engines. ORNL plans to continue its collaboration with PNNL in this area in FY 2006.

\section{Deloro-Stellite Evaluates Scuffing of Alloys for Exhaust Gas Recirculation Systems} Industrial Collaborators: James Wu, Matthew Yao, and George Hansen

\section{HTML: Peter Blau and John Truhan}

Drs. James Wu and Matthew Yao from Deloro-Stellite Corporation, a major U.S. supplier of temperature resisting alloys, visited the HTML to conduct research on the elevated-temperature scuffing characteristics of Co-based alloys. The application of interest concerns a component in diesel engines that enables exhaust gas to be recirculated into the combustion chamber to reduce emissions. The testing techniques used in this work had been initially developed during a previous user project with of Detroit Diesel Corporation (DDC), a major diesel engine manufacturer. Using the HTML's unique "bow-tie" scuffing test system that oscillates a cylinder on a flat tile in a furnace, the Stellite users studied the interrelationships between sliding time and torque, surface finish, and contact damage. 
The characteristics of the wear patterns were used to normalize the torque data obtained during hour-long wear tests in air at $600^{\circ} \mathrm{C}$, and to plot differences in resistance to sliding for eight pairs of well-characterized, candidate alloys (see Fig. 2-5). Differences in behavior are attributed to the differences in oxidation characteristics of the surfaces, the accumulation of wear particles in the sliding interface, and the roughening of the surfaces. Examination of both the upper specimens (pins) and the lower specimens (tiles) was necessary to ensure that the total system wear was minimized. With collaboration between Stellite and HTML tribologists, a new wearmap representation is being developed to help portray the combination of torque and wear characteristics that must be considered in order to select pairs of materials for the optimum high-temperature scuffing resistance in diesel engine EGR system components.

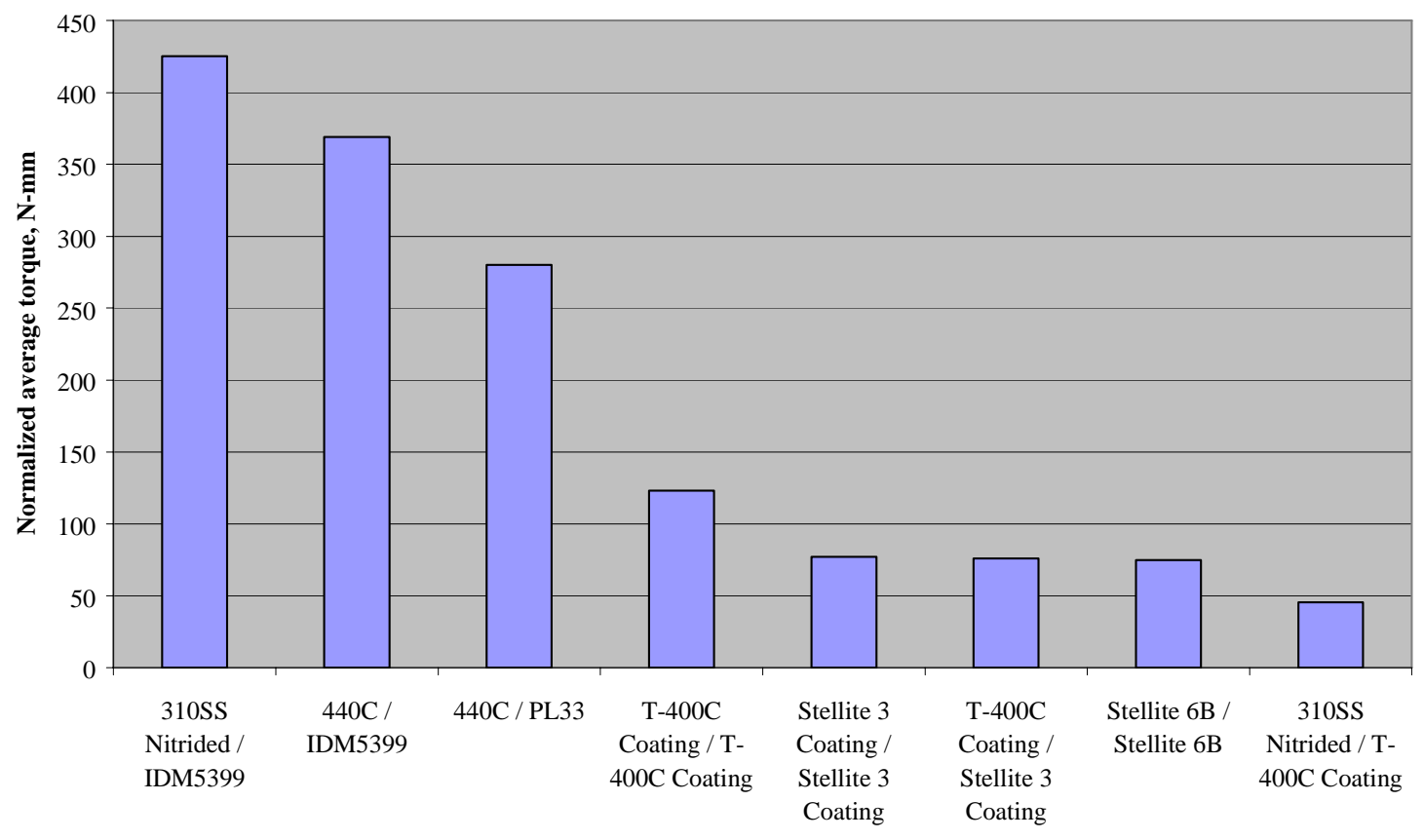

Fig. 2-5. Torque generated from tile/pin wear pairs. There were significant differences in the average torque between candidate pairs of materials for EGR system bearing surfaces. Nitrided stainless steel against a Co-based coating (T400C) had the best performance. 
User Center Members

Edgar Lara-Curzio, Leader

Paula D. Irizarry, Secretary

James G. Hemrick

Roger Jaramillo

Michael J. Lance

Miladin Radovic

Laura Riester

Christopher O. Stevens

Rosa M. Trejo

The MCAUC specializes in the mechanical characterization of functional and structural materials. The center performs mechanical testing and analysis and develops test methods, design codes, and supplemental analytical techniques. Numerous mechanical test frames with uniaxial and multiaxial capabilities are available to visiting researchers from industry and academia to conduct tests in tension, compression, flexure, torsion, shear, and internal pressurization using standard or customized specimens, from cryogenic to elevated temperatures, in air or controlled environments. Facilities also include equipment for micromechanical testing and instrumented indentation. MCAUC staff members have expertise with a wide variety of materials, testing configurations, failure analysis, finite-element stress analysis, analytical modeling, and life-prediction analysis of materials and structures.

\section{MCAUC Instruments}

- Electromechanical, servohydraulic, pneumatic, and dead-weight testing machines for testing in tension, compression, torsion, flexure, axial/torsion, and other loading configurations

- Loading capabilities from a few milligrams up to $500 \mathrm{kN}$, from static up to $20 \mathrm{~m} / \mathrm{s}$ displacement rates and frequencies of $3000 \mathrm{~Hz}$

- High-temperature furnaces (resistance and induction heating, quartz lamps) with capabilities up to $1700^{\circ} \mathrm{C}$ in air and $3000^{\circ} \mathrm{C}$ in vacuum or inert environments

- Integral electronic controllers for load, displacement, and strain control and computerized data acquisition

- Fixtures for uniaxial (3-pt and 4-pt) and biaxial (ring-on-ring) bending, losipescu shear testing, anti-buckling compression, interlaminar shear by compression of double-notched specimens, and fracture toughness by double torsion

- Rotary bend fatigue machine for testing cylindrical specimens in fully reversed cyclic loading

- Environmental test facility for testing in vacuum (down to $1 \times 10^{-9}$ torr), inert gas environments, or pressurized simulated industrial environments from cryogenic to elevated temperatures

- Microturbine test facility for assessing the effects of stress and temperature on the durability of materials for microturbine components

- Acoustic emission detectors, resonant ultrasound spectrometer, and impulse excitation instrumentation for characterization of mechanical integrity and elastic properties of materials and components 
- Instrumented indenters for hardness measurements, including mechanical properties microprobe (nanoindenter) for measuring contact stiffness, elastic and viscoplastic properties, and fracture resistance of thin films and small volumes of material

- Interfacial test system for evaluation of composite interfacial properties by means of singlefiber push-in

- A dynamic mechanical analyzer and a thermomechanical analyzer

\section{Selected Highlights}

\section{Effect of Sr Addition on the Solid-Solution Strengthening of Mg-Al-Ca Alloys}

University Collaborator: Dr. Akane Suzuki

HTML: Dr. Laura Riester and Dr. Edgar Lara-Curzio

The widespread use of magnesium alloys for the manufacture of automotive power train components has been limited by their lack of creep resistance. While small additions of $\mathrm{Sr}$ have been reported to improve their creep resistance, the effect of these additions on other mechanical properties has not been thoroughly characterized.

Dr. Akane Suzuki of the University of Michigan (Fig. 3-1) visited the HTML to work with MCAUC researchers Laura Riester and Edgar Lara-Curzio to determine the effect of Sr additions (between 0 and 3 wt \%) on the yield strength and creep resistance of $A X 53$, which is a magnesium alloy containing $5 \mathrm{wt} \% \mathrm{Al}$ and $3 \mathrm{wt} \% \mathrm{Ca}$. They performed nanoindentation tests in both the intergranular phase and within $\alpha-M g$ grains, which are on average $30-\mu \mathrm{m}$ in size.

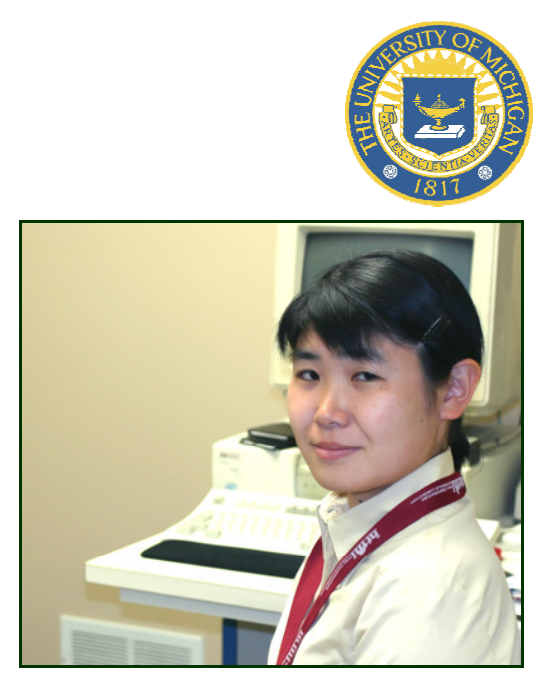

Fig. 3-1. Dr. Akane Suzuki.

It was found that at temperatures between $20^{\circ} \mathrm{C}$ and $175^{\circ} \mathrm{C}$ the flow stress decreased with $\mathrm{Sr}$ concentration and reached a minimum value at $0.5 \mathrm{wt} \% \mathrm{Sr}$ (Fig. 3-2). Figure 3-3 shows the change in hardness and elastic modulus of the $\alpha-\mathrm{Mg}$ grains with Sr content. These values were measured by making indents $1500 \mathrm{~nm}$ deep in the interior of individual grains. The increase in

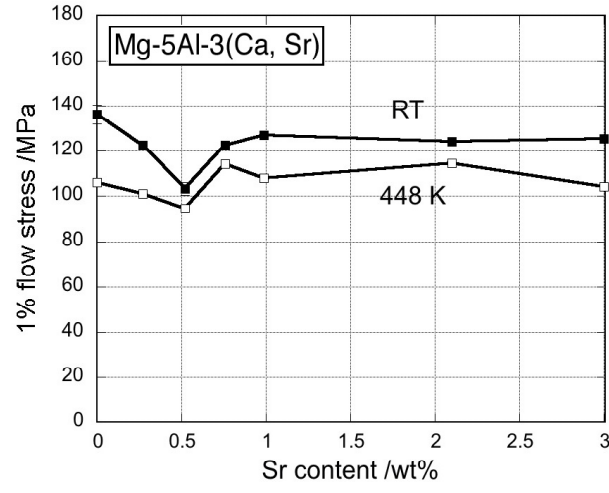

Fig. 3-2. Change in the $1 \%$ flow stress of $\mathrm{Mg}-5 \mathrm{Al}-3(\mathrm{Ca}, \mathrm{Sr}$ ) alloys with $\mathrm{Sr}$ addition, measured by compression method at room temperature and $175^{\circ} \mathrm{C}$.

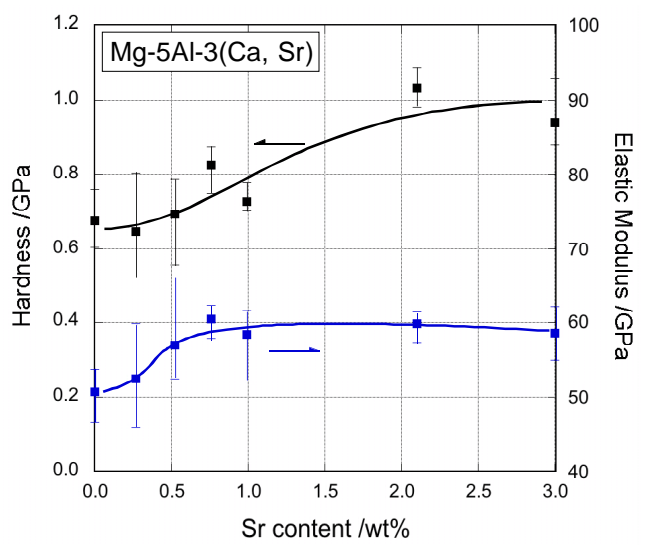

Fig. 3-3. Change in the hardness and elastic modulus of the $\alpha-M g$ phase of the Mg-5Al-3(Ca, Sr) alloys with Sr content, measured by nanoindentation. 
both hardness and elastic modulus with Sr concentration, especially in the range between 0.25 and $1 \% \mathrm{Sr}$ suggests that the increase in the $1 \%$ flow stress in samples containing more than $0.5 \% \mathrm{Sr}$ (Fig. 3-2) is caused by the solid-solution strengthening of the $\alpha$-Mg phase. On the other hand, the decrease of the flow stress in the composition range up to $0.5 \% \mathrm{Sr}$ could be caused by the formation of different intermetallic compounds at grain boundaries. These measurements will be complemented with thorough microstructural analysis of the materials.

\section{Machining-Induced White Layers in Steels for Automotive Components University Collaborator: Sangil Han}

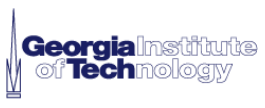

\section{HTML: Laura Riester}

Hard machining processes are widely used in the automotive, heavy vehicle and truck industries. "Hard-machined" steels are characterized by the presence of a "white layer" on their surfaces. For the last several years Professor Shreyes Melkote and his group at Georgia Tech have been studying the characteristics of white layers. During this time, three of his graduate students have visited the HTML to characterize hard-machined steels to identify and understand the mechanisms that are responsible for the formation of white layers.

Graduate student Sangil Han (Fig. 3-4) visited the HTML to work with MCAUC researcher Laura Riester to assess the effect of carbon content, alloying element, heat treatment, and machining speed on the characteristics of the white layer formed on hard-machined 1045, 4340 and 52100 steels. Because of the dimensions of the white layer, which is usually less than $10 \mu \mathrm{m}$ thick, they used ultralow-load nanoindentation to determine the effect of these parameters on hardness and Young's modulus.

The results indicate that alloying elements, carbon content, and heat treatment have a significant influence on white layer formation and its hardness. In general, white layers were

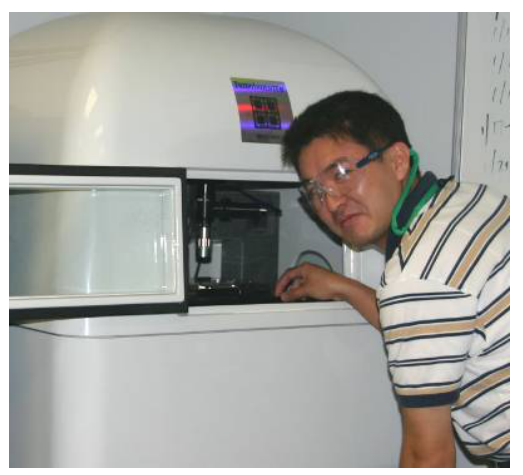

Fig. 3-4. Georgia Tech graduate student Sangil Han. found to be harder than the bulk and transition layers, as illustrated in Figs. 3-5 and 3-6. These results, combined with other characterization work carried out at the HTML will enable better control of the hard machining process.

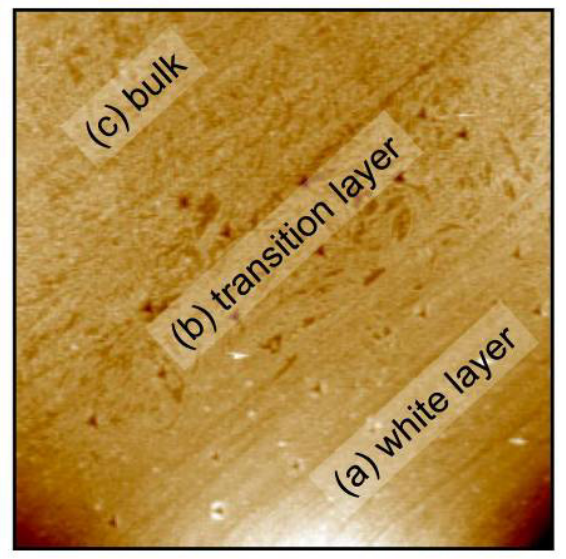

Fig. 3.5. Sample 1045A machined at $300 \mathrm{~m} / \mathrm{min}$ showing the hard white layer, the transition layer and bulk material.

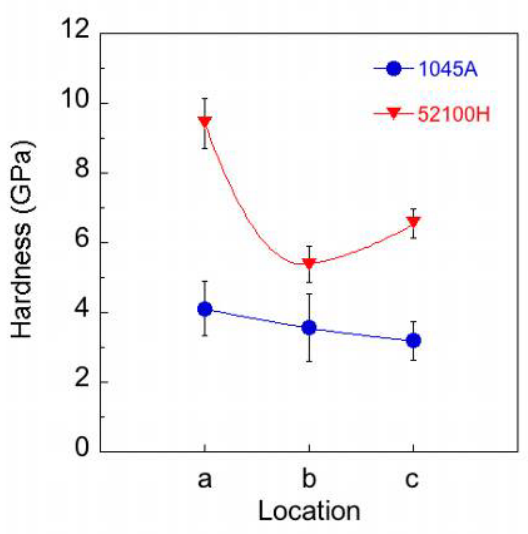

Fig. 3.6. Hardness of samples $1045 \mathrm{~A}$ and $52100 \mathrm{H}$, machined at $300 \mathrm{~m} / \mathrm{min}$, at three different locations. 


\section{Hy-Tech Corp. Develops a Coating to Improve Implant Durability}

Industrial Collaborator: Christopher Klepper

HTML: Dr. Laura Riester and Dr. Peter Blau

The major cause of knee and hip implant loosening is believed to be the result of adverse reactions of the human body to ultrahigh molecular weight polyethylene debris, which is generated as a result of wear between asperities in the metal and the mating polyethylene components. Hy-Tech Corp., a small business located in Knoxville, Tennessee, received funds from the National Institutes of Health through a Small Business Innovation Research (SBIR) project to address this problem. Their proposed solution is focused on smoothing out asperities in Co-Cr-Mo components used in contact with the polyethylene. Hy-Tech engineer Christopher Klepper visited the HTML to work with researchers Laura Riester and Peter Blau to characterize the hardness and surface characteristics of Co-Cr-Mo alloys and similar alloys coated with amorphous boron. Using HTML's triboindenter, they measured the hardness of the alloy and the rougher embedded carbides and compared the results with those obtained for a similar component coated with a thin layer (150 nm thick) of amorphous boron. It was demonstrated that the boron coating modifies the stiffness and hardness of the surface enough so that it could reduce the wear process.

\section{Gamma Completes User Project}

Industrial Collaborator: Denny Ross

\section{HTML: Bill Hendrich, Roger Jaramillo, and Edgar Lara-Curzio}

$\mathrm{SiC}$ is an attractive material for nuclear fuel cladding application because it has the potential to significantly increase burnups for light-water reactors and because it could make possible certain generation IV reactor concepts, such as the Super Critical Water Reactor. Gamma Engineering Corp., which is a small business located in Rockville, Maryland, has developed $\mathrm{SiC} / \mathrm{SiC}$ duplex structures for nuclear fuel cladding applications. These duplex structures, which consist of a hollow monolithic $\mathrm{SiC}$ tube surrounded by a braided $\mathrm{SiC} / \mathrm{SiC}$ composite layer have several favorable properties, including hermeticity and the potential for strength retention up to $1000^{\circ} \mathrm{C}$. However, their mechanical behavior is largely unknown.

During FY 2005 Gamma Engineering Corp.'s Denny Ross (Fig. 3-7) visited the HTML on several ocassions to work with MCAUC researchers Bill Hendrich, Roger Jaramillo, and Edgar Lara-Curzio to evaluate the hoop strength of $\mathrm{SiC} / \mathrm{SiC}$ duplex tube test specimens that had been manufactured by different routes. The research is being conducted for DOE's Office of Nuclear Energy under an SBIR grant. They used a test method developed at ORNL based on the uniform internal pressurization of the duplex tubes by subjecting an incompressible polyurethane insert to axial compression. Test specimens included monolithic cylinders of $\mathrm{SiC}$ surrounded by composite layers of fiber-reinforced $\mathrm{SiC}$ in which the matrix had been densified by either

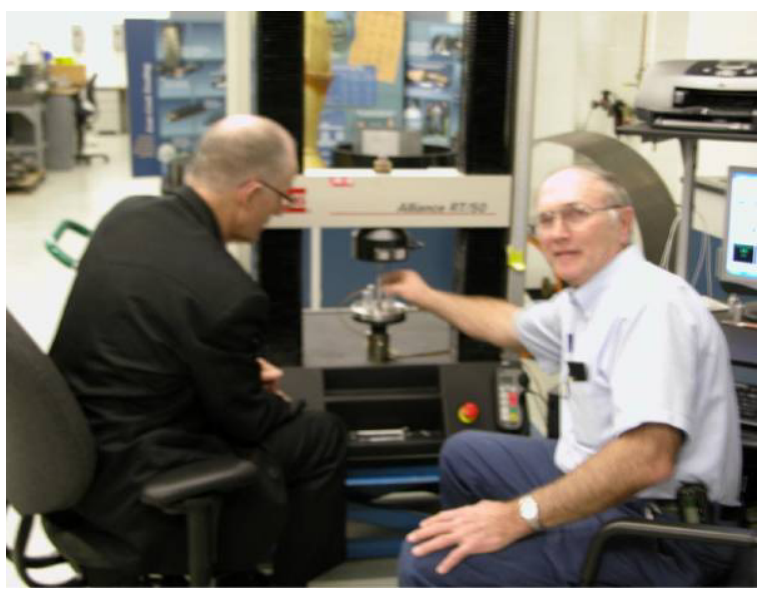

Fig. 3-7. Gamma engineer Denny Ross (left) with MCAUC's Bill Hendrich, preparing a burst strength test. chemical vapor deposition or polymer infiltration and pyrolysis. Most of the duplex structures were impermeable, which is a requirement for fuel cladding applications. 
Some $\mathrm{SiC} / \mathrm{SiC}$ duplex tubes exhibited hoop strength values in excess of $300 \mathrm{MPa}$, and it was demonstrated that the composite layer provided damage tolerance and a graceful noncatastrophic mode of failure (see Fig. 3-8). The latter was an important finding because high strain capability offers improved safety margins for the classical "reactivity-initiated accident," which is a key factor limiting the burnup extension of existing zircaloy cladding.

\section{Deformation Induced by Equal Channel Angular Processing (ECAP)}

University Collaborator: Grigoreta Stoica HTML: Laura Riester

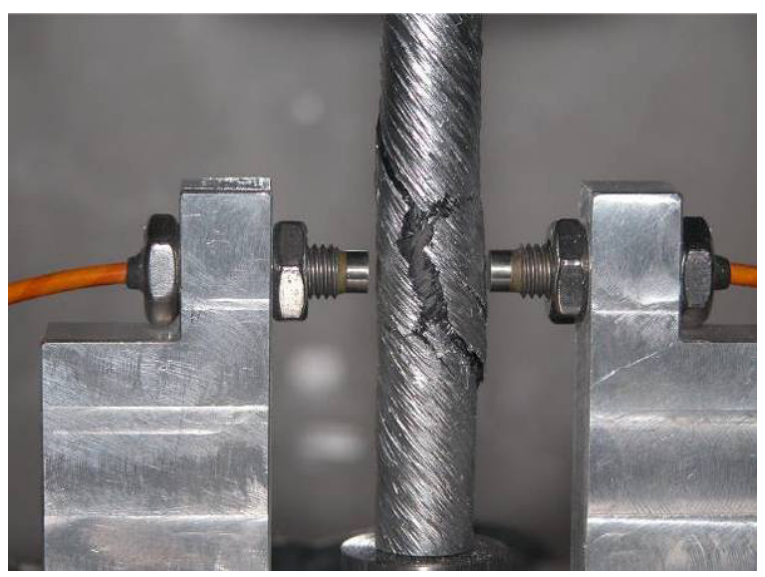

Fig. 3-8. SiC duplex structure at the end of burst strength test.

When metals and alloys are subjected to severe plastic deformation via equal channel angular processing (ECAP), they exhibit novel mechanical properties, such as better strength and ductility and even superplastic behavior. University of Tennessee researcher Grigoreta Stoica (Fig. 3-9) is collaborating with HTML researchers to identify the mechanisms that are responsible for the deformation experienced by materials during ECAP in order to predict the microstructure and mechanical behavior of the deformed materials.

As part of an HTML User Project Mrs. Stoica worked with MCAUC researcher Laura Riester to quantify the hardness of pure copper that had been deformed through ECAP. For these measurements, they used a nanoindenter that was programmed to obtain indents at various locations of the flow surface (Fig. 3-10). Work is in progress to correlate the nanohardness results with the shear-strain mapping obtained on the flow surface of each sample after one pass of ECAP deformation. In turn, those results will aid in the development of predictive models and constitutive equations.

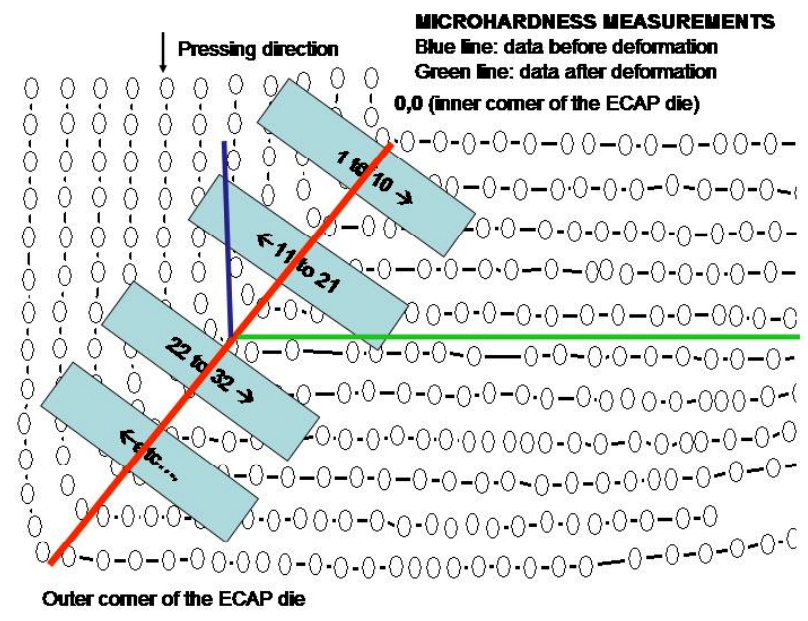

Fig. 3-10. Location of nanohardness measurements obtained in a billet deformed by ECAP.

\section{Pratt \& Whitney Characterizes the Constituents of Ceramic Matrix Composites \\ Industrial Collaborator: Greg Ojard \\ HTML: Dr. Laura Riester}

The design of ceramic matrix composite components requires knowledge of the properties of the composite constituents, particularly their elastic properties, because many of these components are designed to perform in the linear elastic regime of the composite material. Most ceramic matrix composites rely on a very thin compliant coating around each fiber to facilitate crack deflection, fiber debonding, and fiber 
sliding, which are three of the most important micromechanical mechanisms responsible for the tough behavior of these materials. The dimensions of these coatings pose a challenge for the determination of their elastic properties, but it constitutes an ideal case for the application of nanoindentation techniques.

Pratt \& Whitney engineer Greg Ojard returned to the HTML to work with MCAUC researcher Laura Riester to determine the mechanical properties of $0.1-\mu \mathrm{m}$-thick BN fiber coatings in Sylramic ${ }^{8}$ fiber-reinforced SiC composites (Fig. 3-11). Using HTML's new Hysitron triboindenter, they found that the elastic modulus of the BN coatings was $22 \mathrm{GPa}$ and that predictions made from this input information of the elastic properties of the composite were in good agreement with those determined experimentally for the composite.
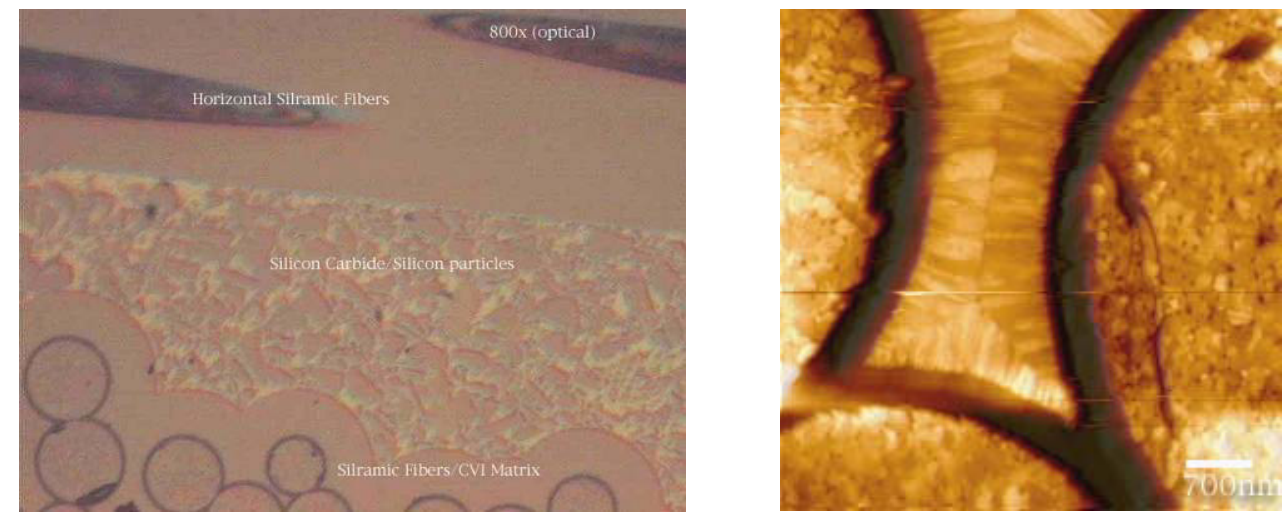

Fig. 3-11. Micrographs of Sylrami® fiber-reinforced ceramic matrix composite containing a $0.1-\mu \mathrm{m}$-thick BN coating around each fiber. HTML's new Hysitron triboindenter was used to obtain the image on the right.

\section{Fracture Behavior of $\mathrm{Si}_{3} \mathrm{~N}_{\mathbf{4}}$ Reinforced with Nanotubes}

University Collaborators: Prof. Enrique Barrera and Erica Corral

Rice UNIVERSITY

\section{HTML: Dr. Edgar Lara-Curzio and Amit Shyam}

The incorporation of single-walled carbon nanotubes in metallic, ceramic, and polymeric matrices promises the development of composite materials with improved thermal, electrical, and mechanical properties. For example, silicon nitride posses a relatively low thermal conductivity and fracture toughness, and efforts have been focused on improving those properties by tailoring the material microstructure through lengthy sintering procedures and starting powder compositions. Professor Enrique Barrera and his research group at Rice University are considering an alternative approach in which single-wall carbon nanotubes (SWCNTs) are dispersed in the silicon nitride matrix by colloidal processing methods. The composite is subsequently consolidated by spark plasma sintering.

Professor Barrera and graduate student Erica Corral worked with MCAUC researchers Amit Shyam and Edgar Lara-Curzio to evaluate the fracture toughness of silicon nitride reinforced with SWCNTs (Fig. 3-12). The fracture toughness of scaled test specimens was determined according to ASTM C1421, by subjecting precracked beam test specimen to three-point bending. While it was found that carbon nanotubes were able to bridge cracks in the silicon nitride matrix (Fig. 3-13) their contribution to the fracture toughness of the composite was very small. The major factor affecting fracture toughness was found to be the sintering temperature. 


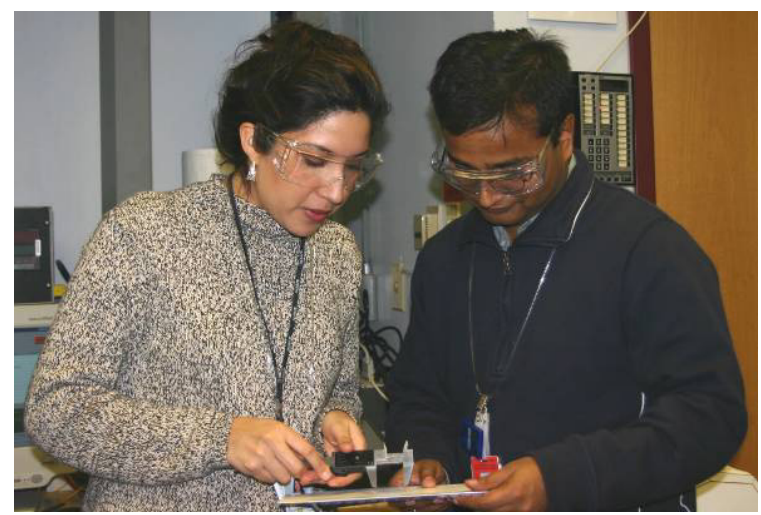

Fig. 3-12. Rice University graduate student Erica Corral and MCAUC's Amit Shyam.

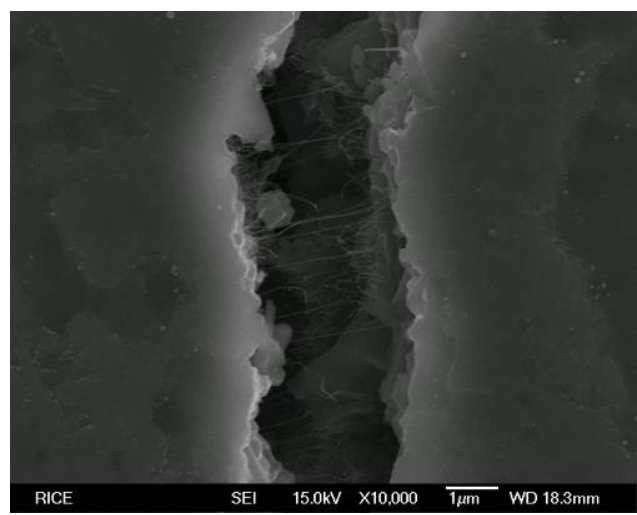

Fig. 3-13. SEM micrograph shows crack bridging in SWCNT-reinforced silicon nitride.

\section{Mechanical Properties of Biodegradable Antimicrobial Chitosan Films}

University Collaborators: Prof. Svetlana Zivanovic and Gagan Rajpal

HTML: Miladin Radovic, Laura Riester, and Edgar Lara-Curzio

Chitosan is the name given to polymers that are obtained by the deacetylation of chitin (poly-b1,4-D-N-acetylglucosamine). In industrial-scale procedures, chitin is produced by treating seafood waste, especially shells from crustaceans (e.g., shrimp, crabs, lobsters).

Chitosan is biodegradable and microbicidal, and it has the ability to bind to metal ions, proteins, and lipids. Therefore, it can be used for many applications (e.g., water purification, air filtration, food packaging, and skin transplants). Chitosan, although not soluble in water, quickly dissolves in aqueous acid solutions and forms films, membranes, and fibers upon evaporation of the solvent.

Professor Svetlana Zivanovic and her group at the University of Tennessee, Knoxville, are using this approach to develop thin films of chitosan. They are investigating the effect of residual water and the type of the acid used on the characteristics of the film. For example, lower molecular weight acids, such as $\mathrm{HCl}$ and acetic acid, yield brittle and hard films whereas acids with larger molecular weight, (e.g., lactic and citric acid), yield thicker and more flexible films. Professor Zivanovic and graduate student Gagan Rajpal (Fig. 3-14) visited the HTML to work with MCAUC researchers Miladin Radovic, Laura Riester, and Edgar LaraCurzio to assess the effect of acid, residual water, and test temperature on the storage and loss moduli of the

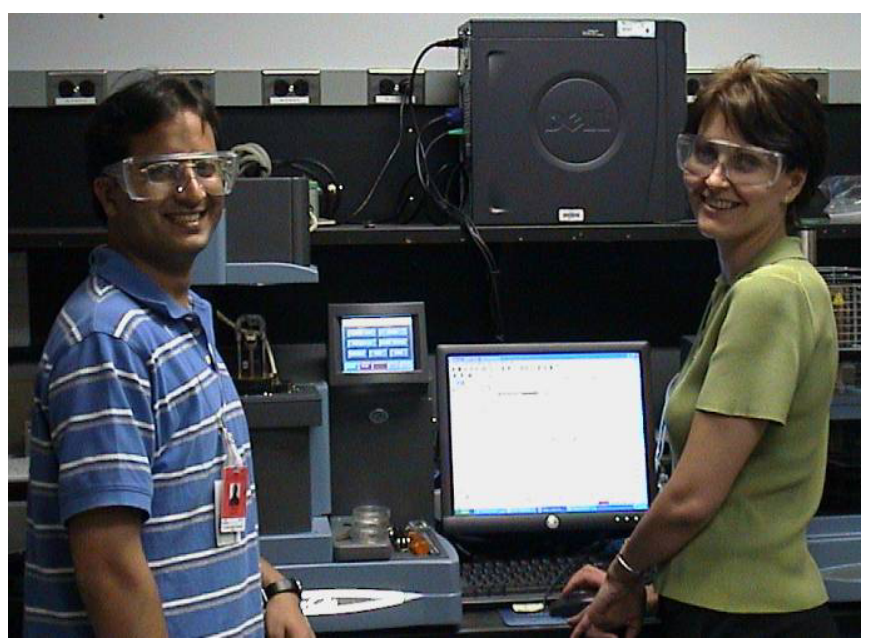

Fig. 3-14. Prof. Svetlana Zivanovic, University of Tennessee, Knoxville, (right) and graduate student Gagan Rajpal performing dynamic mechanical analysis of chitosan thin films.

chitosan films using Dynamic Mechanical Analysis (Fig. 3-15). It was found, for example, that wet films exhibit three loss modulus peaks that are related to the freezing and evaporation of 


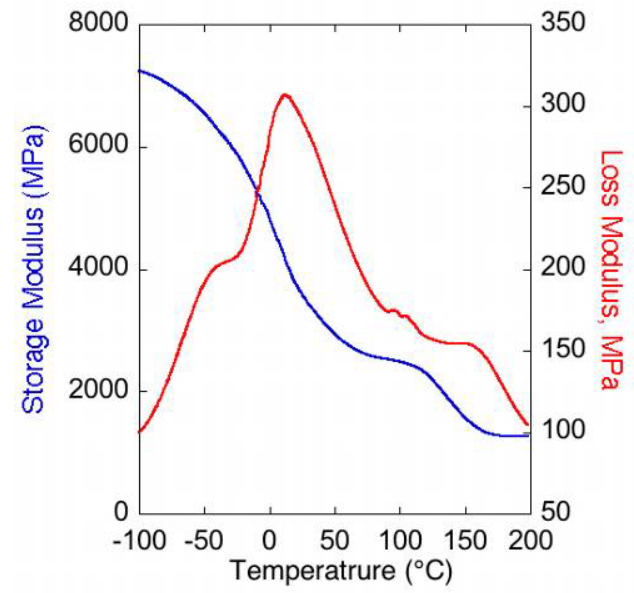

Fig. 3-15. Storage and loss moduli of chitosan.

binders of very small thickness $(0.1-0.5 \mathrm{wt} \%)$ to manufacture permanent magnets by dynamic magnetic compaction. IAP is investigating the processing parameters and organic binder compositions that will optimize the mechanical strength, ductility, and resistance to environmental degradation. Dr. Bhanu Chelluri of IAP, along with Professor R. Sooryakumar and undergraduate student Chris Clark of Ohio State University (Fig. 3-16), returned to the HTML to work with MCAUC researchers Rosa Trejo and Edgar LaraCurzio to evaluate the compressive and four-point bending strength of permanent magnets processed by dynamic magnetic compaction and with different resins and magnetic powders (Figs. 3-17 and 3-18). These results are being complemented with fractographic analyses to understand how the materials fail. The success of this research will lead to lighter, stronger, and more durable permanent magnets for automotive and other applications.

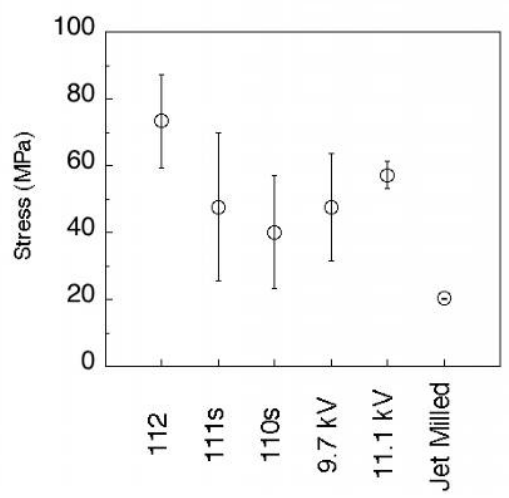

Fig. 3-17. Effect of processing conditions on the four-point bending of bonded magnets.

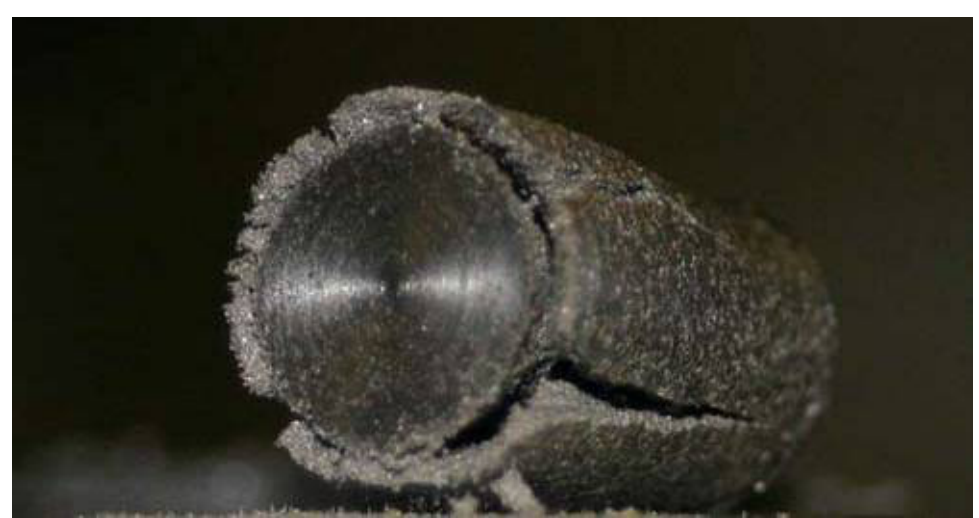

Fig. 3-18. Photograph of bonded test specimen M20979-M after compression testing. Note the core-shell structure. 


\section{Students Spend Summer at MCAUC}

Graduate students George Nelson and Chris Green of Georgia Tech, Resheemah Burrell of Florida State University, and Siddhartha Pathak of Drexel University spent the summer of 2005 working as research assistants at MCAUC (Fig. 3-19).
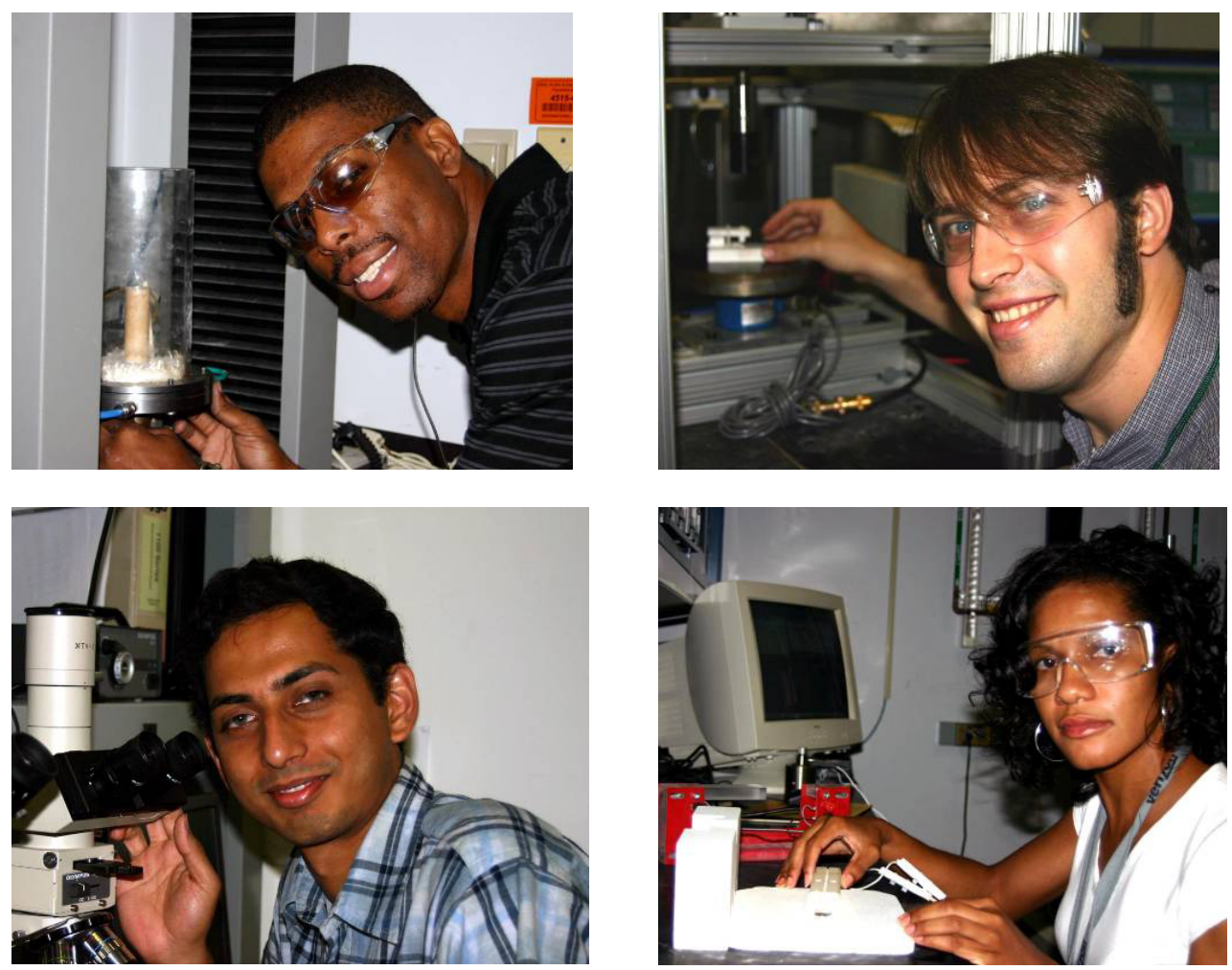

Fig. 3-19. Student research assistants. Upper left: Chris Green. Clockwise: George Nelson, Resheemah Burrell, and Sid Pathak.

George and Chris worked under the guidance of MCAUC researchers Edgar Lara-Curzio, Miladin Radovic, and Amit Shyam to study the effect of environment and temperature on the mechanical properties of materials for solid-oxide fuel cells. George and Resheemah worked under the guidance of MCAUC researchers Edgar Lara-Curzio and Amit Shyam to assess the effect of water vapor on the fracture behavior of cordierite porous ceramics that are used for diesel particulate filters. Mr. Pathak worked under the guidance of MCAUC researchers Edgar Lara-Curzio and Miladin Radovic to quantify the effect of calcium additions and $\mathrm{pO}_{2}$ on the dimensional stability of $\mathrm{LaCoO}_{3}$, which is a mixed-ion/electronic conducting perovskite material with attractive properties for the fabrication of sensors and solid-oxide fuel cell components.

\section{Lara-Curzio Chairs Symposium}

MCAUC group leader Edgar Lara-Curzio chaired the Symposium on Mechanical Properties and Performance of Engineering Ceramics and Composites as part of the Twenty-ninth International Cocoa Beach Conference held in Cocoa Beach, Florida, January 23-28, 2005. The Cocoa Beach meeting is the premier international forum for the dissemination of information pertaining to the processing, properties, and behavior of structural, multifunctional ceramics and ceramic matrix composites, emerging ceramic technologies, and application of engineering ceramics. 



\title{
4. DIFFRACTION USER CENTER (DUC)
}

\author{
User Center Members \\ Andrew Payzant, User Center Leader \\ Geneva Worley, Administrative Assistant
}

\section{Scott Speakman \\ Claudia Rawn \\ Jianming Bai \\ Cam Hubbard}

The DUC uses variable-temperature laboratory and synchrotron X-ray and neutron diffraction techniques to characterize metals, ceramics, and polymers. DUC staff members have worked on funded projects that require high pressure, adding the capabilities of a diamond anvil cell for use with $X$ rays and a pressure cell fabricated from single-crystal sapphire for use with neutrons. A collaboration for studying hydrogen storage materials with scientists from the Neutron Program for Materials Research at Chalk River Laboratories (Chalk River, Ontario, Canada) initiated the design and construction of a pressure cell that will use hydrogen (deuterium) The neutron powder diffractometer at the High Flux Isotope Reactor (HFIR) is currently being upgraded; however, DUC staff have funded projects for collaborating at other neutron-scattering facilities [the Los Alamos Neutron Scattering Science Center (LANSCE), the NIST Center for Neutron Research (NCNR), Chalk River Laboratories, and the ISIS Pulsed Neutron and Muon Source] to continue studies where neutrons with sensitivity to some elements such as hydrogen, nitrogen, carbon, and oxygen are required as well as for studying the magnetic structure.

Users are scientists and engineers from academic, industrial, and DOE national laboratory backgrounds who collaborate with DUC staff and use the instruments when diffraction data are needed. The diffraction facilities are also extensively used by qualified staff members in the Materials Science and Technology Division, who are conducting a wide variety of ceramic and alloy research and development efforts sponsored by DOE and other agencies. DUC staff members also lead and participate in DOE- and ORNL-funded projects.

The DUC continues to accommodate a large number of user projects of current interest in the field of materials science and engineering. The results are used to relate materials processing and performance with phase transformations, lattice expansion, atomic structure, and phase stability issues that need to be determined before many of the new materials can be used in applications as components with improved properties. Projects in FY 2005 included studying materials for potential use in fuel cells, multipollutant sorbents, photovoltaics, thin films for a variety of applications, ferrielectric liquid crystals, alloys with high melting points that are strong at high temperatures, materials used in medical imaging, microwave dielectrics for wireless communications, and biosynthesized magnetic nanoparticles. Accomplishments by DUC staff in FY 2005 include the following:

- More than 30 research papers were co-authored by DUC staff and users in FY 2005.

- Oral and poster presentations were given at technical meetings, including the Metallurgical Society (TMS) and American Crystallographic Association Annual meetings, the Denver X-ray Conference, the ASM Materials Solutions Conference, and the American Conference on Crystal Growth and Epitaxy (ACCGE-16). 
- C. J. Rawn serves on the Chapter Council of ASM International, the executive committee of the Oak Ridge Chapter of ASM International, and the organizing committee of the ACCGE-16.

- C. J. Rawn is a joint faculty member of the University of Tennessee's Department of Materials Science and Engineering.

- S. A. Speakman served on the executive committee of the Oak Ridge Chapter of ASM International.

- E. A. Payzant serves on the editorial committee of Advanced Materials and Processes magazine, chairs the nonambient diffraction subcommittee for the ICDD, and chaired a session titled "Industrial Applications of XRD" at the Denver X-ray Conference.

- C. R. Hubbard continues to serve on the International Centre for Diffraction Data board of directors and organized a session at Denver X-Ray Conference.

- Payzant, Speakman, and Hubbard were instructors at the Georgia Tech Non-ambient Diffraction Workshop in November 2004

\section{DUC Instruments}

- Neutron powder diffractometer (low and high temperatures)

- Philips X'Pert Pro X-Ray Diffractometer (high temperature, controlled environment)

- Scintag PADV X-Ray Diffractometer

- Scintag PADX X-Ray Diffractometer (high temperature, controlled environment)

- Scintag XDS2000 X-Ray Diffractometer (low temperatures down to $15 \mathrm{~K}$ )

- Synchrotron X-Ray Beamline X-14A (low and high temperatures)

\section{Selected Highlights}

\section{Purdue Examines Stability of YSZ Topcoats for Gas Turbines}

University Collaborators: R. W. Trice and Z. Chen

HTML: S. Speakman, H. Wang, and J. Howe

Utilizing complementary capabilities and instruments at three of the HTML User Centers (DUC, TPUC, and MAUC), researchers from Purdue University evaluated the effects of vanadium oxide contamination on the phase stability and thermal properties of $7 \mathrm{wt} \%$ yttria stabilized zirconia (YSZ). As shown in Fig. 4-1, the vanadium contamination at $800^{\circ} \mathrm{C}$ degraded the YSZ, with both monoclinic zirconia and zirconium vanadate

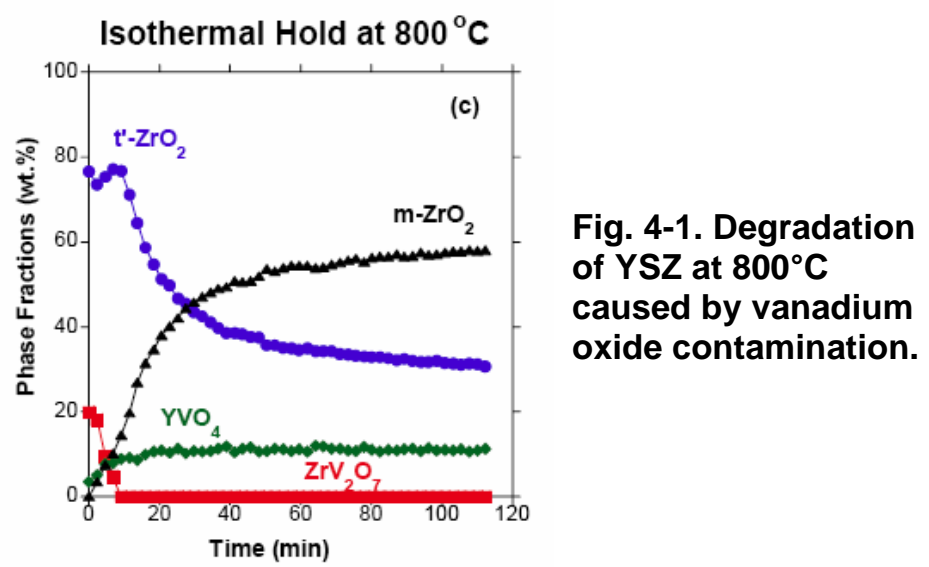
being formed in less than $10 \mathrm{~min}$.

\section{Hydrogen Separation and Hydrogen Storage Materials Studied In Situ At HTML} ORNL Collaborator: Joachim Schneibel

HTML: Scott Speakman

Scott Speakman attended the MRS 2004 Fall Meeting in Boston, where he presented a paper on structure-property characterizations of ceramic proton conductors. Scott also presented a 
poster describing his work on sodium alanate hydrogen storage materials, work done at HTML in collaboration with ORNL researcher Joachim Schneibel. This research was also the topic of an invited talk at the 2005 ACA Annual meeting.

\section{Tennessee Tech Studies Freezing and Melting of Water in Cement}

University Collaborator: Joseph Biernacki

HTML: Jianming Bai

The freezing of pore water in cement can induce internal stress and can cause degradation of concrete structures. A better understanding of the thermodynamics of this process is important in studies of concrete and cement materials. A new research project, lead by Professor Joseph

Biernacki of Tennessee Tech University, was initiated at beamline X14A, the HTML synchrotron X-ray facility at the National Synchrotron Light Source (NSLS) to investigate the freezing and melting behavior of water confined in cement-based materials. The beamline's cryostat was used to cool cement powder samples from room temperature to $135 \mathrm{~K}$. In this preliminary study, X-ray diffraction peaks of pore ices were detected and identified upon freezing. More detailed and systematic studies are planned.

\section{Georgia Tech Studies Low Thermal Expansion Ceramics}

University Collaborators: A. P. Wilkinson, K. White, and M. Kutukcu

HTML: A. Payzant

Researchers from Georgia Tech recently published results of experiments conducted at HTML on low thermal expansion phosphates, which are structurally similar to $\mathrm{ZrP}_{2} \mathrm{O}_{7}$, but with a 50:50 mixture of group III and group $\mathrm{V}$ cations in place of $\mathrm{Zr}$. Where zirconium phosphate undergoes a transformation to a low thermal expansion phase at $290^{\circ} \mathrm{C}$, no transition was observed for any of these new compounds. $\mathrm{Al} / \mathrm{Ta}$ and $\mathrm{In} / \mathrm{Nb}$ phosphates had comparatively high thermal expansion coefficients similar to the low-temperature form of zirconium zirconate, but $\mathrm{Y} / \mathrm{Nb}$ phosphate had a much lower coefficient of thermal expansion, similar to that of the high temperature form of zirconium phosphate. Such studies contribute to development of materials with precisely engineered thermal expansion characteristics.

\section{CTI Molecular Imaging Determines the Composition of Lutetium Aluminate Crystals} CTI Molecular Imaging Collaborators: C. Melcher and .M. Spurrier HTML: S. Speakman, C. Rawn, C. Hubbard, and W. Porter

Single crystal cerium-doped $\mathrm{LuAlO}_{3}$ has the potential of being used in numerous applications, including nuclear medicine, security monitoring, geophysical exploration, and nondestructive testing, where efficient and fast scintillators are required. $\mathrm{LuAlO}_{3}$ has the perovskite structure (denoted LuAP), space group Pnma, and the composition is highly dependent on the crystal growth conditions. X-ray powder diffraction studies are being used to study the crystal structures and the presence of secondary phases in order to explain some of the scintillating properties. In most cases data from the crystals indicate that only the $\mathrm{LuAlO}_{3}$ is present. However, in some cases the crystal will decompose to a second binary phase that has the garnet structure, $\mathrm{Lu}_{3} \mathrm{Al}_{5} \mathrm{O}_{12}$ (denoted $\mathrm{LuAG}$ ), and $\mathrm{Lu}_{2} \mathrm{O}_{3}$. Other samples revealed the presence of $\mathrm{Lu}_{3} \mathrm{Al}_{5} \mathrm{O}_{12}$ and an additional phase, possibly $\mathrm{Lu}_{4} \mathrm{Al}_{2} \mathrm{O}_{9}$, for which the crystal structure is presently unknown. Two students were funded for an eight-week period through the UT/ORNL Chancellor's Internship to continue various aspects of this work. 


\section{AIN Thin Films Characterized by High-Temperature $X$-Ray Reflectivity-University of Florida}

University Collaborators: C. Abernathy and D. Stodilka HTML: S. Speakman

Dielectrics composed of AlN thin films on SiC substrates may be used as power invertors for electric vehicles or the electric-drive component of hybrid vehicles. However, failure modes due to temperature must be understood in order to improve reliability in the service environment. For this purpose, these films were studied at the HTML using high-temperature $\mathrm{X}$-ray reflectivity. This marks the first time that hightemperature X-ray reflectivity data have been collected at the HTML. As opposed to the diffraction peaks often used to characterize phase composition or residual stresses, X-ray reflectivity measures interference fringes to evaluate the thickness, surface roughness, and integrity of the thin films. As shown in Fig. 4-2, the AlN film maintained integrity up to $700^{\circ} \mathrm{C}$, indicating that failure in these films at lower temperatures may be due to electric breakdown or other mechanisms.

\section{Palladium-Based Membranes Studied in Hydrogen by In Situ X-Ray Diffraction}

University Collaborators: Y. H. Ma, F. Guazzone, and E. Ayturk

\section{HTML: A. Payzant and S. Speakman}

Composite palladium membranes are of great interest for hydrogen purification and ultrapure hydrogen production. The Center for Inorganic Membranes Studies, at Worcester Polytechnic Institute, has focused its efforts on improving stability over time and hydrogen flux of Pd-alloy membranes prepared by the electroless plating method. Two doctoral students from the Worcester Polytechnic Institute prepared samples of $\mathrm{Pd}, \mathrm{Pd}-\mathrm{Ag}$, and $\mathrm{Pd}-\mathrm{Cu}$, which were examined under inert and reducing conditions at temperatures up to $550^{\circ} \mathrm{C}$, using the high temperature X-ray diffractometers at the HTML. The PANalytical MPD $X$-ray diffractometer enabled in situ studies of thermal mismatch stresses between the film and the hastelloy substrate as well as stresses resulting from dilation of the palladium alloy due to intercalation of hydrogen. The Scintag X-ray diffractometer was used to determine the kinetics of alloy formation from $\mathrm{Pd}$ and $\mathrm{Ag}$ precursors through the collection of many hundreds of time-resolved diffraction patterns, each taken in tens of seconds, under isothermal conditions (Fig. 4-3).

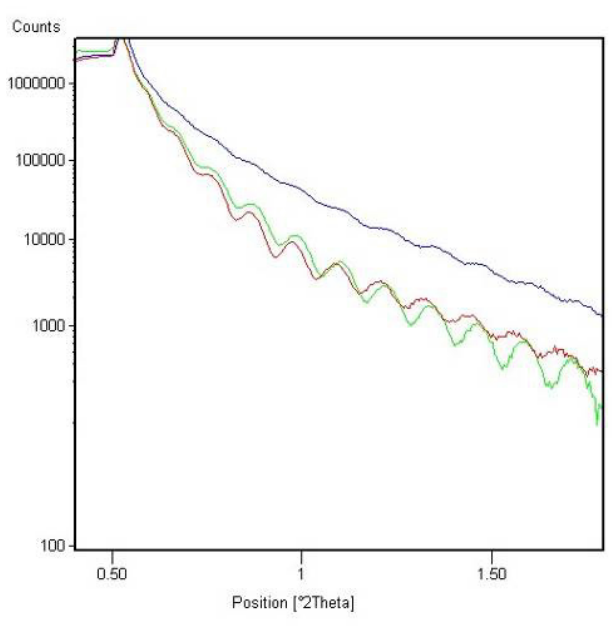

Fig. 4-2. X-ray reflectivity patterns collected from AIN thin film at $25^{\circ} \mathrm{C}$ (red), $700^{\circ} \mathrm{C}$ (green), and $1000^{\circ} \mathrm{C}$ (blue). The film maintained integrity up to $700^{\circ} \mathrm{C}$, and only began to fail when heated to $1000^{\circ} \mathrm{C}$, marked by the loss of well-defined interference fringes.

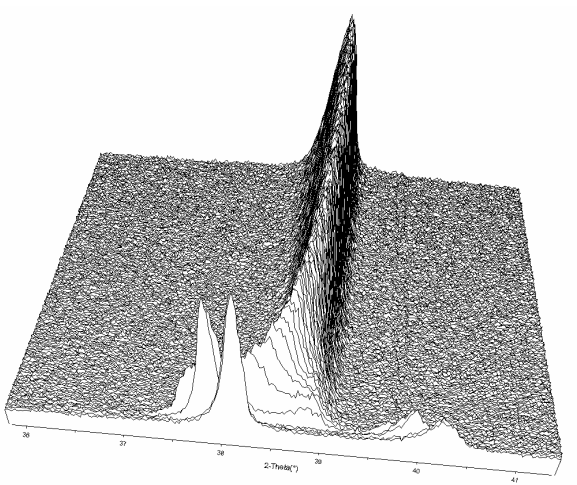

Fig. 4-3. Pd-Ag grain growth as a function of time. The front-most pattern shows the as-fabricated film with separate $\mathrm{Ag}$ and $\mathrm{Pd}$ peaks in an inert atmosphere, followed by heating to $300^{\circ} \mathrm{C}$ (shifting the peaks to the left due to thermal expansion), after which an $\mathrm{H} 2$ atmosphere was introduced. The formation of the AgPd alloy was monitored as the sample was heated from $\mathbf{5 0 0}$ to $650^{\circ} \mathrm{C}$. 
HTML and Georgia Tech Organize Workshop on High Temperature X-Ray Diffraction

A workshop titled "Practical High-Temperature Powder Diffraction: How to Do It Right" was held at Georgia Tech on November 8, 2004, with approximately 30 participants from across the United States. Workshop instructors included Payzant, Hubbard, Watkins, and Speakman from the HTML, plus Drs. Robert Snyder and Mike Haluska from Georgia Tech, Martijn Franzen from PANalytical, Inc. (Netherlands) and Petra Kotnik from Anton Paar GmbH (Austria).

\section{HTML Participates in High-Resolution Powder Diffraction Short Course}

In January 2005, HTML's synchrotron X-ray beamline X14A and two other beamlines at the NSLS hosted a 3-day short course on "High Resolution Powder Diffraction Data Collection and Analysis" using synchrotron X rays. Fifteen graduate students, post-docs, and scientists from national labs and universities attended the course (Fig. 4-4). HTML's Cam Hubbard gave two presentations, titled "High Temperature X-ray Diffraction and Uses of X14A" and "Additional Resources for Practical and Successful High Temperature X-ray Diffraction and Structural Studies by XRD."

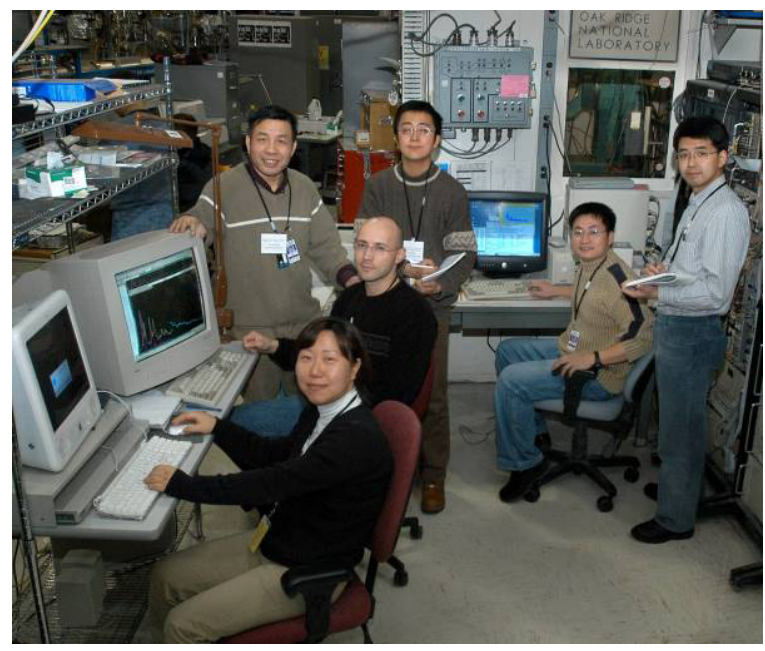

Fig. 4-4. Short course participants getting hands-on experience with synchrotron based powder diffraction at HTML's synchrotron beamline: Eun Ok Chi (University of Houston), Sergey Ushakov (University of California at Davis), Jianming Bai (HTML-ORNL, instructor), Peng Gao (New Jersey Institute of Technology), Xiongfei Shen (University of Connecticut), and Atsushi Hubo (Princeton University). 



\title{
5. RESIDUAL STRESS USER CENTER (RSUC)
}

\author{
User Center Members \\ Camden R. Hubbard, User Center Leader \\ Geneva N. Worley, Group Secretary
}

\author{
Ke An (Postdoctoral Fellow) \\ Jianming Bai (UT Research Associate) ${ }^{a}$ \\ William Bailey (Postmaster Student) \\ O. Burl Cavin (UT Research Associate) ${ }^{b}$ \\ Hahn Choo (Joint UT Faculty-ORNL Staff) ${ }^{b}$ \\ E. Andrew Payzant ${ }^{a}$ \\ Fei Tang (Postdoctoral Fellow) \\ Thomas R. Watkins \\ a across multiple user centers \\ ${ }^{b}$ part time
}

HTML user projects and DOE programs are increasingly concerned with life prediction and failure analysis of engineering components and structures and how to increase life via beneficial compressive stresses near the surface. In many cases, knowledge of residual stress gradients (sign and magnitude) as a function of location at both the surface and throughout the volume of a component is critical information for failure analysis and for developing life prediction models. The RSUC was established to meet this need by providing facilities and expertise for measuring and for assessment of methods for controlling residual stresses through modifications in the forming, surface treating, and finishing processes; changes in the design; or application of stress-relief procedures. Residual stress measurements at HTML are also increasingly being used to develop and validate advanced computational models.

RSUC users also characterize the nonrandom grain distribution, known as texture, in materials and relate the results to directionally dependent materials properties using the same experimental facilities as used for residual stress. Texture is very common in materials subjected to deformation as well as in thin films, coatings, and other materials of increasing technological importance.

RSUC provides three principal stress measurement capabilities at three locations: the X-ray residual stress facilities in the HTML and 4508 buildings at ORNL, the ORNL synchrotron beamline X14A at the National Synchrotron Light Source (NSLS), and the Neutron Residual Stress Mapping Facility (NRSF2) at the High Flux Isotope Reactor (HFIR) at ORNL. Together, the three facilities, unique in themselves, make RSUC an unparalleled resource, able to address a wide range of challenging stress and texture measurement needs for both industry and academia. These diffraction facilities are not only utilized to measure macro (long-range) and micro (short-range) residual stress and texture at the surface of and within polycrystalline materials, but also to provide fundamental knowledge of intergranular stresses arising during plastic deformation. 


\section{RSUC Instruments}

- Powder-texture-stress (PTS) four-axis goniometer with 18-kW X-ray rotating anode

- PTS four-axis goniometer with 2-kW X-ray tubes

- PANalytical X'Pert Pro X-ray diffractometer with high-temperature stages (shared with the Diffraction User Center)

- X14A synchrotron high-flux, highly parallel X-ray beamline (shared with the Diffraction User Center)

- $\quad$ Large-specimen X-ray stress analyzer with automated mapping

- $\quad$ The second-generation Neutron Residual Stress Mapping Facility (NRSF2)

\section{Leveraging Major Research Facilities}

The NRSF2 is located at the HFIR, which is one of the two highest-flux steady-state sources of neutrons in the world. The HTML's development of NRSF2 is leveraged on the operating, maintenance, and HFIR upgrade programs of the DOE Office of Science. Similarly, the RSUC and DUC activities at the NSLS X14A beamline benefit greatly from the Office of Science sponsorship of NSLS.

\section{New Instrument Status: NRSF2}

Commissioning of the NRSF2 and the mechanical properties load frame continued throughout FY 2005. Major design, fabrication, and installations accomplished in FY 2005 included

- the 3-ton monorail crane,

- the seven-detector array and shielding,

- preliminary slits for the detector array, and

- permanent mounts for alignment transits enhancement to the data collection codes.

Major progress in software for data collection, load frame control, real-time data processing, and calibration algorithms was also accomplished, and user documents were prepared. Intermixed with the installation and commissioning, a number of appropriate user projects were launched to test the entire NRSF2 system. RSUC resumed operational status for users who conducted studies involving neutron strain, texture, and phase mapping.

In November 2004 the performance gains resulting from the upgrades of HFIR beam tubes, shutters, and NRSF2's new double crystal, doubly focusing monochromator were characterized. The intensity and peak width obtained from $\mathrm{Ni}$ and Fe samples that were characterized prior to the upgrades were compared with results obtained on NRSF2. The diffraction peak and profile data sets for the same test specimens measured under similar conditions were normalized for gauge volume differences and count time differences. Table 5-1 summarizes the ratios of peak intensity and full width at half maximum (FWHM) for the two samples. The instrument intensity performance gain exceeded 10x, and the diffraction peaks are substantially sharper than they were before the upgrades.

Table 5-1. NRSF2 performance gains in neutron diffraction peak for Si331AF monochromator

Phase/hkl Peak intensity ratio FWHM ratio

Fe $211 \quad 10 \quad 0.60$

The difference in peak intensity ratios is partially due to differences in effectiveness of monochromator focusing and small differences in inherent strain broadening in each sample. Both gains contribute to improvements in determination of peak position and hence accuracy in strain determination. The data indicate that data collection rates are sufficient to enable selected 
real time experiments such as studies of (1) intergranular stresses during continuous loading, (2) low cycle fatigue, and (3) to follow stress relaxation after an overload.

The design, fabrication, and installation of the seven-detector array for the NRSF2 were completed in May 2005 (Fig. 5-1). The design goal was to collect a much larger fraction of the diffracted neutrons and thereby to increase the data collection rate and peak position accuracy. ORNL lift plans for hoisting and rigging the 1100-lb assembly were approved, and the unit was successfully installed. Following calibration, the detector array, equipped with temporary slits, was put to use on user projects, and background measurements were obtained to determine the need for additional neutron shielding.
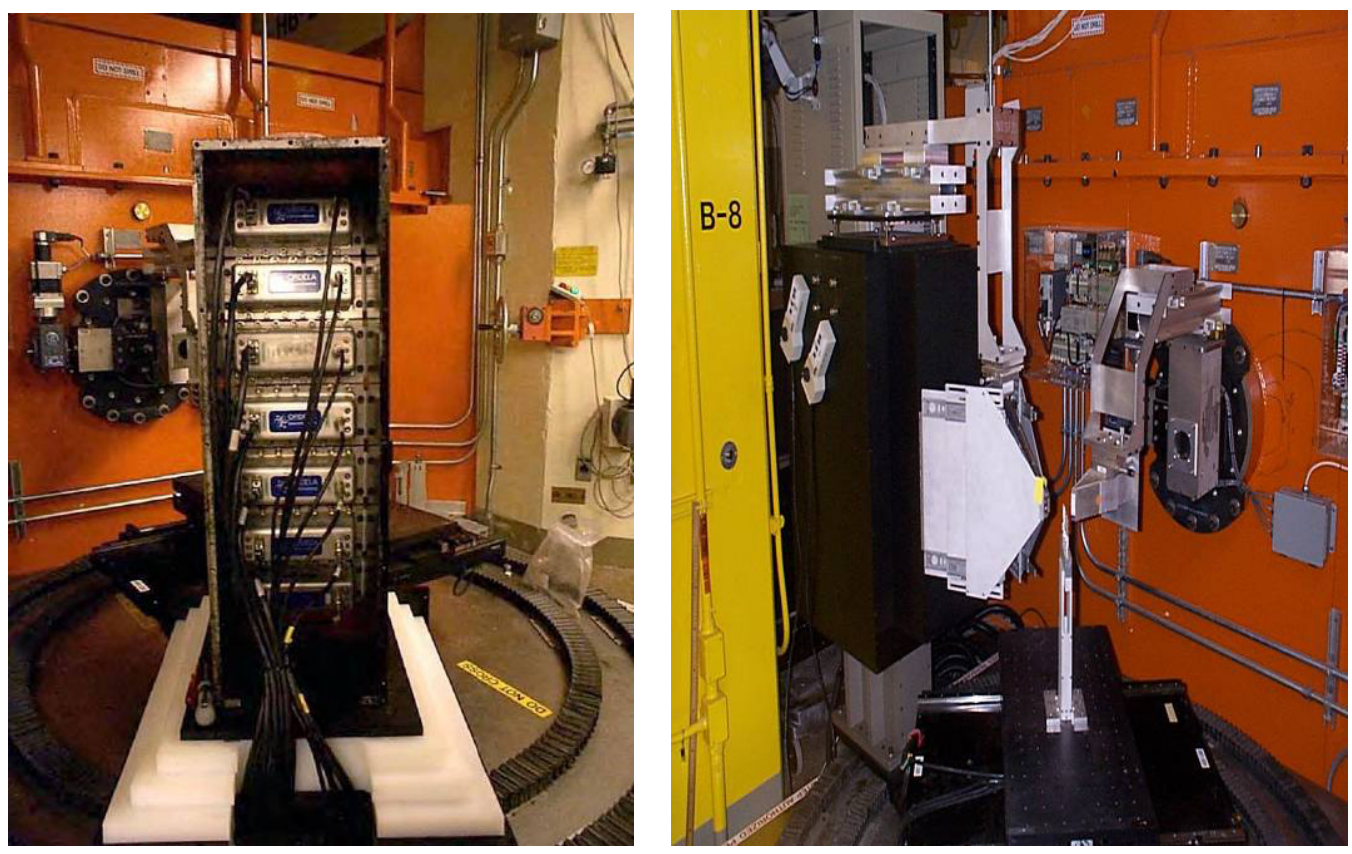

Fig. 5-1. (left) The seven linear position-sensitive detectors in the mounting frame during installation on NRSF2. (right) A shielding box (black) was mounted over the frame, and a diffracted beam slit holder was mounted on the front of the shielding box.

Besides the gains due to increased flux and the greater detector area coverage, the new NRSF2 has many other features that also benefit industrial and academic users:

- An advanced monochromator system that enables users to choose between six wavelengths from 1.45 to $2.67 \AA$ with computer-controlled horizontal bending to optimize diffraction focusing for different sample d-spacings. The multiple wavelengths enable strain mapping in a large range of polycrystalline materials. For example, the longest wavelength was used to map the location of $\mathrm{ZrH}_{2}$ precipitates in hydrogen-charged zircalloy.

- Major increase in load capacity of the rotary stages and translation tables. The new system allows measurement of larger specimens (to $500 \mathrm{~kg}$ on the XY stages). Measuring large samples is one of the special design goals of NRSF2. Future addition of radial collimators will further enhance the ability to characterize strains as they improve gage volume definition within large components.

- Improvements in accuracy and reproducibility, allowing the user to accurately position a sample to within $0.01 \mathrm{~mm}$ and then to alternate between different wavelengths. The goal of strain measurement to better than $50 \mathrm{ppm}$ has been met, even when changing wavelengths during a measurement campaign. 
- The ability to add in situ accessories such as a load frame (highlighted below), furnaces, and process simulators. The load frame is the primary accessory requested by the user community for fundamental studies of materials behavior by neutron diffraction (intergranular stresses during deformation).

- Kappa and 2-circle orienters to enable measurement of the strain tensor and studies of strains in large single crystals and highly textured samples.

\section{Two LDRD Projects Awarded for FY 2005 Involve NRSF2-RSUC}

Two Laboratory Directed Research and Development (LDRD) projects involving the NRSF2 instrument were awarded funding for FY 2005. The first, receiving renewal funding, was "Development of In Situ Neutron Diffraction Capabilities for Studies of Deformation and Fracture Behavior under Hydrogen-Rich Environments," led by Hahn Choo [University of Tennessee (UT) and RSUC] and Camden Hubbard (RSUC). This project aimed to develop in situ load frames and environment cells to be used on NRSF2 for studies of materials behavior by neutron diffraction. The features include 5000-lbf load capacity, uniaxial loading (tension or compression), automated and remote control, fully reversible tension-compression fatigue, and the ability to accommodate environmental cell attachments. As reported last year, this ORNLsupported effort was a positive factor in the National Science Foundation's (NSF's) awarding a Major Research Instrumentation (MRI) grant to UT-ORNL for development of in situ loading and furnace facilities for use at VULCAN at the Spallation Neutron Source (SNS).

The second approved LDRD project was a new proposal titled "In-Situ Time-Resolved Neutron Diffraction Study of Materials Behavior under Severe Thermo-Mechanical Deformation," led by Z. Feng (Metals and Ceramics Division) and included Camden Hubbard (RSUC), Hahn Choo (UT and RSUC), and Xun-Li Wang (SNS). This two year project's goal is to develop in situ, realtime neutron diffraction tools and expertise to study thermomechanical deformations such as friction stir welding (FSW). Progress and accomplishments on these two LDRD projects are summarized below.

\section{Load Frame for In Situ Mechanical Testing at NRSF2 Successfully Tested and Applied for User Projects}

The load frame (Fig. 5-2) adds a new and valuable capability to the recently commissioned NRSF2 neutron diffractometer at HFIR. The load frame is rated for uniaxial tension or compression up to $5000 \mathrm{lbf}$ (about $22 \mathrm{KN}$ ). It allows in situ mechanical testing studies that provide simultaneous measurements of global and mesoscopic (intergranular) strains from extensometer and neutron diffraction, respectively. The load frame operation and data acquisition are fully automated using LabVIEW DAQmx (Fig. 5-2c) that is interfaced to the NRSF2-MAP data collection package.

Preliminary studies were performed on a series of commercial aluminum alloys. The tensile stress-strain data of the Al-2024 alloy measured using the new load frame agree well with the data collected by the ORNL Mechanical Properties Group (See Table 5-2 and Fig. 5-3.)

Furthermore, development of intergranular strains for various crystallographic orientations of Al2024 was measured along the longitudinal direction (parallel to the loading axis) by neutron diffraction. The results are valuable in understanding the microscopic deformation behavior and in validating deformation model predictions. 

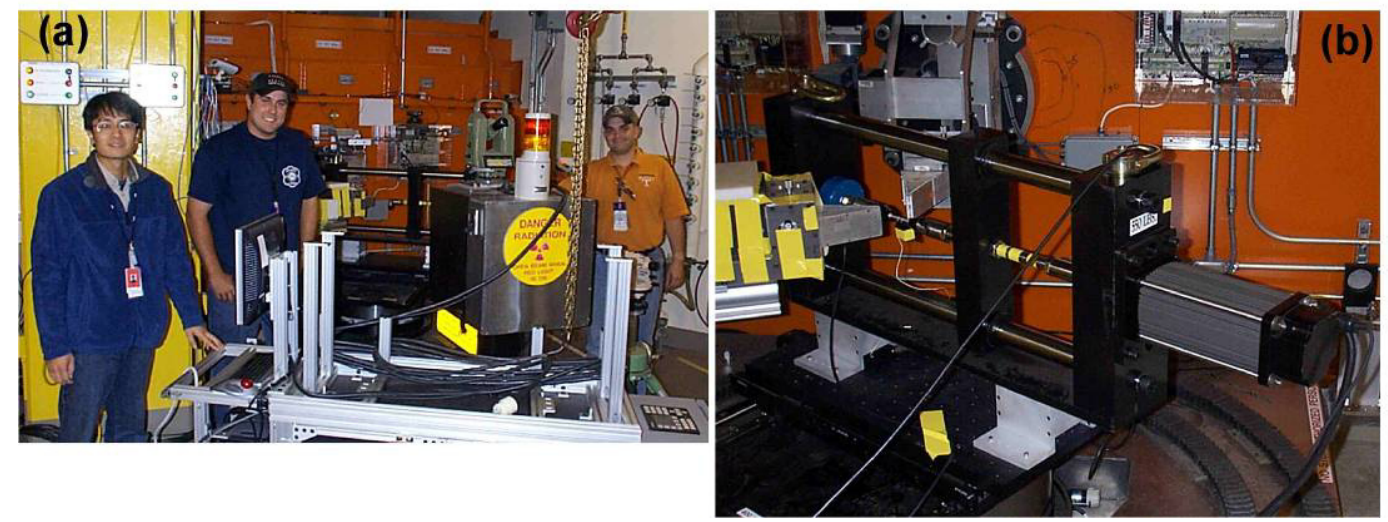

Fig. 5-2. (a) RSUC team members after successfully mounting the new load on the NRSF2 instrument. (b) Close-up of the new load frame. (c) LabView control panel.

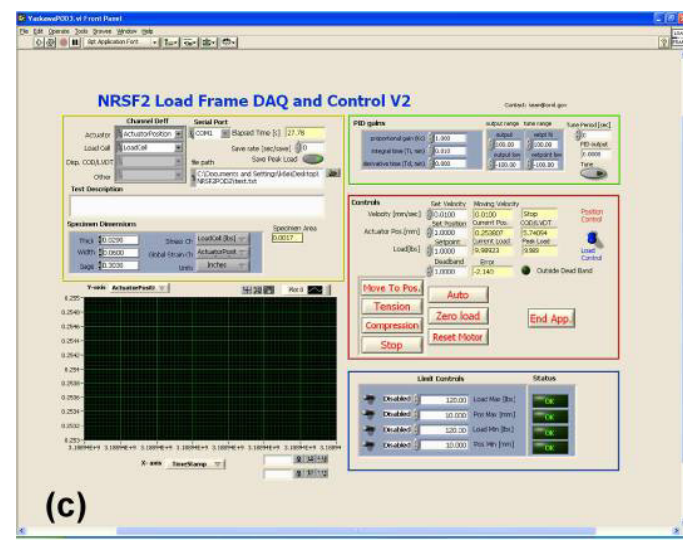

Table 5-2. Comparison of load frame performance

\begin{tabular}{lcccc}
\hline Load frame & $\begin{array}{c}\mathbf{0 . 2} \% \text { yield stress } \\
(\mathbf{M P a})\end{array}$ & $\begin{array}{c}\text { Strain at } \mathbf{0 . 2} \% \text { yield } \\
\text { stress } \mathbf{( \% )}\end{array}$ & $\begin{array}{c}\text { Young's modulus } \\
(\mathbf{G P a})\end{array}$ & $\begin{array}{c}\text { Stress at break } \\
(\mathbf{M P a})\end{array}$ \\
\hline MPG & 118 & 0.362 & 76.9 & 271 \\
NRSF2 & 123 & 0.394 & 76 & 275 \\
\hline
\end{tabular}
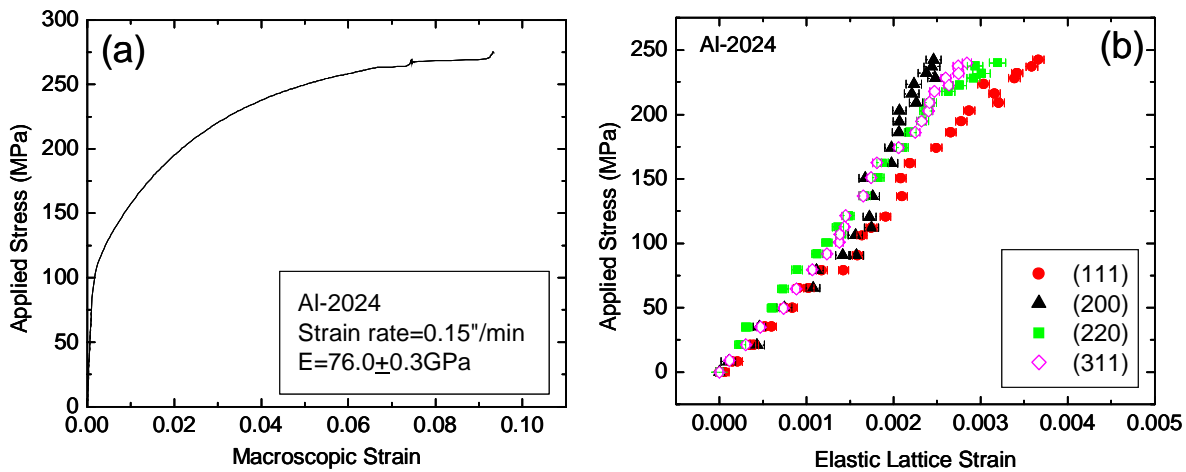

Fig. 5-3. (a) Macroscopic stress-strain curve of an Al-2024 alloy measured using the new NRSF2 load frame. (b) Corresponding intergranular strains measured for various crystallographic planes by neutron diffraction during a tensile test. 


\section{In Situ Real-Time Neutron Diffraction Study of Materials Behavior under Thermally Induced Stresses Demonstrated}

University of Tennessee graduate student W. Woo of the Materials Science and Engineering Department, University of Tennessee, Knoxville, worked with Prof. H. Choo (UT and RSUC), Z. Feng and S. David of the Metals and Ceramics Division Joining Group and RSUC team members K. An, W. Bailey, and C.R. Hubbard in an LDRD-sponsored study of how to perform real-time, in situ neutron diffraction measurements of materials deformation processes. Under rapid and, severe thermal and mechanical deformation, the material state changes (e.g., temperature, stress, and microstructure) are of intense interest in materials science and engineering. The deep penetration capability of neutrons enables in situ characterization of mechanical properties and structures. However, the neutron diffraction is typically limited to "static" behavior due to low flux.

A new technique, which can make possible neutron diffraction studies when the material deformation strain-rate is far beyond conventional neutron data collection rates, is being developed and tested. In this method, in situ time-resolved neutron measurements are based on a quasi-steady state (QSS) phenomenon. In the QSS the 3-D distribution of material states is stationary in the Eulerian coordinate system, where the observation point is fixed to the processing zone. Normally, one uses a Lagrangian coordinate system, where the material state is described in the laboratory coordinate system. The goal was to establish the equivalency of the two measurement methods in a special case.

Figure 5-4 shows the basic experimental setup performed at RSUC's NRSF2. Thermal stresses were imposed on a local spot on a 6061-T6 aluminum alloy plate using an electric heating gun. Careful temperature control provides a uniform thermal distribution within the neutron scattering volume (approximately $5 \times 5 \times 2 \mathrm{~mm}$ ). First, the direct or Lagrangian measurements were performed by moving a heat source toward the fixed neutron beam position. Real-time data were collected every $20 \mathrm{~s}$ while the

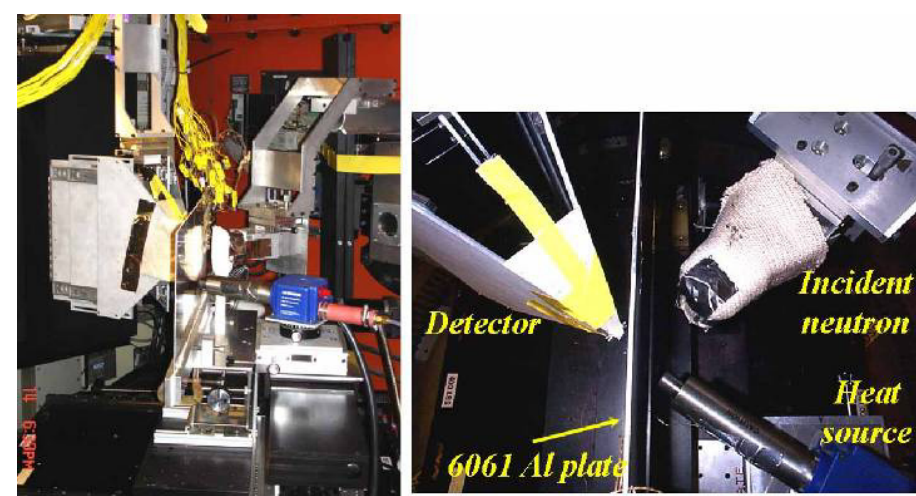

Fig. 5-4. Setup of the heat gun and 6061 aluminum plate on the NRSF2 neutron strain-mapping instrument. heat source was moving at $1 \mathrm{in} . / \mathrm{min}$. For the QSS measurements, the relative distances between a fixed neutron beam and fixed heat source position were set up for each data point, and then neutron measurements were collected for $10 \mathrm{~min}$ while the plate was moved during the measurements. The lattice spacing within the QSS period of measurement is constant, indicating the material state remains steady state.

The comparison between the direct and QSS measurement of the transient response by the localized heat source using in situ real-time neutron diffraction is shown in Fig. 5-5. The validity of the QSS method was clearly demonstrated by comparing the QSS data to the direct measurements. Thus, the developed QSS technique can imply that the neutron collection time associated with the neutron flux and sampling volume could be independent to the rate of change of material states in a transient process that involves a quasistatic steady state. The 


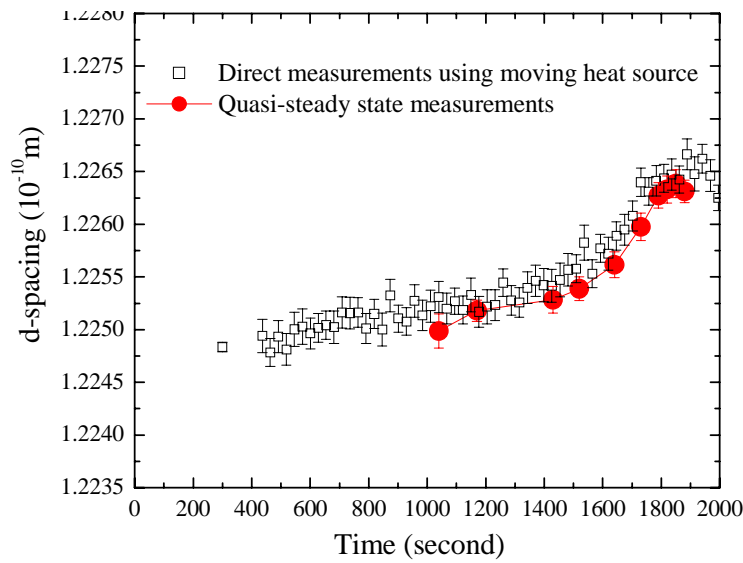

Fig. 5-5. Comparison of direct and quasisteady state measurements shows the equivalence of the two methods.
QSS measurement was repeated ten times, corresponding to ten different locations relative to the heat gun.

The excellent agreement of $d$-spacing for the two methods demonstrates that when faster processes involving a QSS condition are to be studied, using a QSS method with repeated measurements can be successfully used. Future plans are to use the QSS method for in situ studies of the strain and temperature fields around the tool for friction stir welding.

\section{Selected Highlights}

RSUC continues to address critical industrial and academic problems, typically using a combination of RSUC and other HTML

facilities. The following highlights were selected to display the scope of activities conducted in the RSUC and the growing use of a combination of the RSUC instruments to use a comprehensive measurement or mapping of stress to enhance life prediction, understand failure, guide improvement in manufacturing processes, and address fundamental science.

\section{Marlow Industries Measures Texture at Elevated Temperatures in Shape Memory Alloys Using a New Heated Stage Designed by RSUC for Use on 4-axis Diffractometers-Marlow Industries}

Industrial Collaborator: J. Sharp

\section{HTML: T. R. Watkins and O. B. Cavin}

Shape memory alloys (SMAs) are exciting new materials with a variety of uses. There are two shape memory effects: heat transformation and load transformation. In the former, the soft martensitic phase of the SMA is deformed at room temperature. Upon heating to the austenitic temperature, the SMA transforms into the hard austenitic phase and returns to its original shape. The part is then cooled to room temperature. This heat transformation effect is used by Marlow Industries in wing flap control for aircraft. For load transformation the temperature may be held constant. Load transforms the austenite phase to martensite. Upon removal of the load, the martensite transforms back to austenite, and the material returns to its original shape. This load transformation effect is used in eyeglass frames and cell phone antennae.

A researcher from Marlow visited the RSUC to measure the crystallographic texture on bulk samples of $\mathrm{Ni}_{50} \mathrm{Ti}_{50} \mathrm{SMA}$ in the austenite state at $200^{\circ} \mathrm{C}$. This particular SMA has a high transition temperature by design. A new high-temperature $x$-ray diffraction stage designed for the PTS goniometers (see Fig. 5-6) goes up to $500^{\circ} \mathrm{C}$ with excellent temperature uniformity, which was confirmed with an IR camera $\left(<5^{\circ} \mathrm{C}\right.$ variation across sample and heating plate). The $\mathrm{Ni}_{50} \mathrm{Ti}_{50}$ SMAs were produced by Texas $\mathrm{A} \& \mathrm{M}$ via equal channel angular extrusion, which introduces strong texture (highly oriented grains). From studies of single crystals, we know that properties of SMAs, such as the percentage of recoverable phase transformation strain and fatigue and creep behavior, are strongly orientation dependent. Texture is probably one of the most important parameters due to its correlation with the functional response of shape memory and must be carefully controlled when SMAs are used in critical applications. 
The goal is to optimize all of the microstructural factors in SMA materials via novel

thermomechanical treatments (i.e., ausforming and marforming)that provide evolution of different texture components, depending on the processing route selected, in addition to grain refinement. The results (see Figs. 5-7 and 5-8) will be used to modify the parameters for a visco-plastic self-consistent crystal plasticity model and to validate texture predictions as a function of processing route. These measurements will also inform us which processing route will result in the best austenite texture, essential for obtaining cyclic stability of recoverable transformation strain. This research will save Marlow time and resources by reducing the amount of processing cycles and by helping to improve the model that can be used for prediction of texture evolution under different thermomechanical conditions.

\section{RSUC Assists Tennessee Tech with Cement-Based Materials Research}

Collaborators: J. J. Biernacki and C. J. Parnham

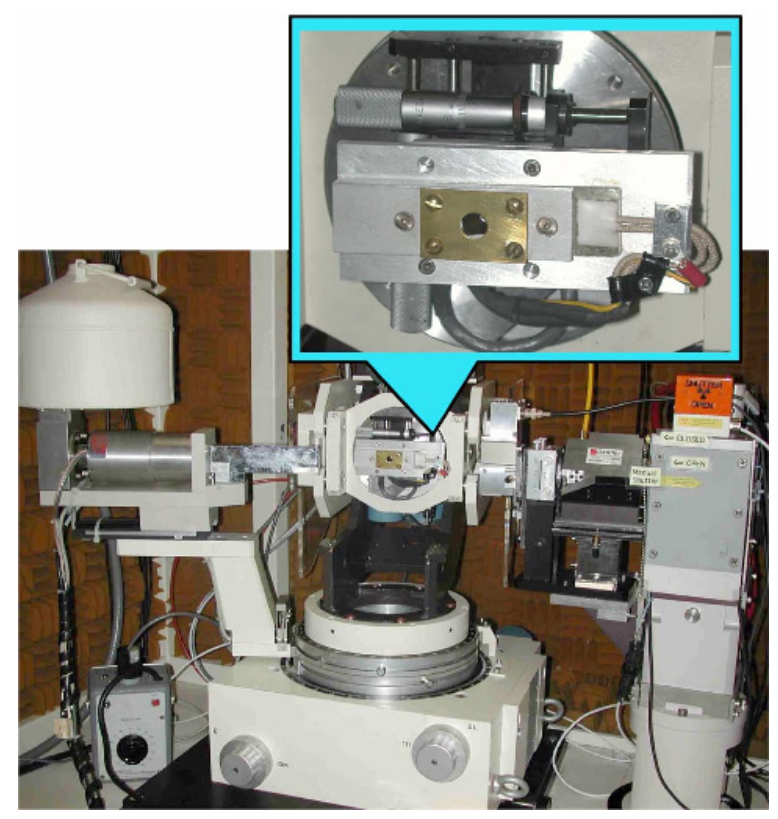

Fig. 5-6. The new elevated-temperature stage (inset) mounted on the 4-axis X-ray goniometer provides new RSUC capabilities for stress and texture measurements at elevated temperature.

\title{
HTML: J. Bai, T. R. Watkins, and C. R. Hubbard
}

Concrete is one of the most ubiquitous building materials on the earth. Still, improvements are sought for degradation resistance due to mechanical loading, thermal stress, and chemical attack. While concrete is composed of cement (the binder), sand, aggregate, and water, cement paste (cement + water) was studied as a first step for simplicity. Researchers from Tennessee Tech visited the RSUC's X14A beam line at the NSLS. Known loads were applied to cement cubes in situ on the goniometer, and the strains were measured (Fig. 5-9). The monochromatic, high flux X-ray beam was critical to observing and resolving the weak peaks from this multiphase material. The method implemented showed resolution and precision to determine strains on the order of $10^{-5}$. Young's moduli were also determined to be $50 \mathrm{GPa}$, which is in reasonable agreement with the literature. Future work is planned using Raman and neutron work at NRSF2.

\section{RSUC Assists with Retained Austenite Determinations-Georgia Tech}

\author{
Collaborators: S. N. Melkote and S. Han
}

\section{HTML: T. R. Watkins and L. Riester}

The advent of new cutting tool materials, such as polycrystalline cubic boron nitride, increases the feasiblity of turning hardened materials (> $45 \mathrm{HRC}$ ). However, while surface finish in hard turning may be comparable to that in grinding, undesirable microstructure change, specifically the formation of a white layer, has become a hurdle in its widespread acceptance by industry. Despite knowledge of various characteristics of the white layer, its formation mechanisms are not fully understood. It is commonly believed that white layer in hard turning of steels is produced primarily by thermally-induced metallurgical phase transformation resulting from rapid 


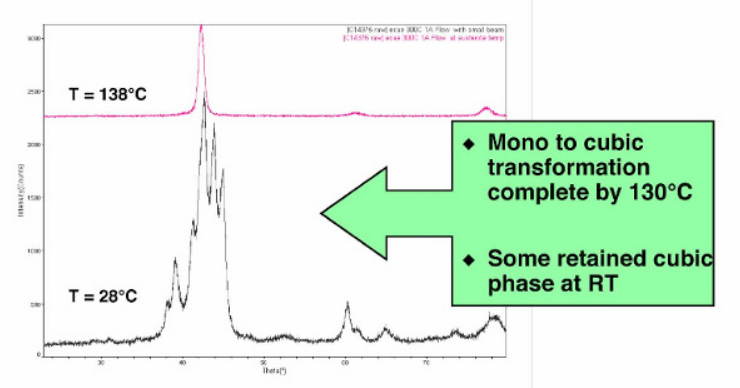

Fig. 5-7. Diffraction patterns of the Ni50Ti50 shape memory alloy showing transformation from monoclinic to cubic for temperatures above $130^{\circ} \mathrm{C}$.
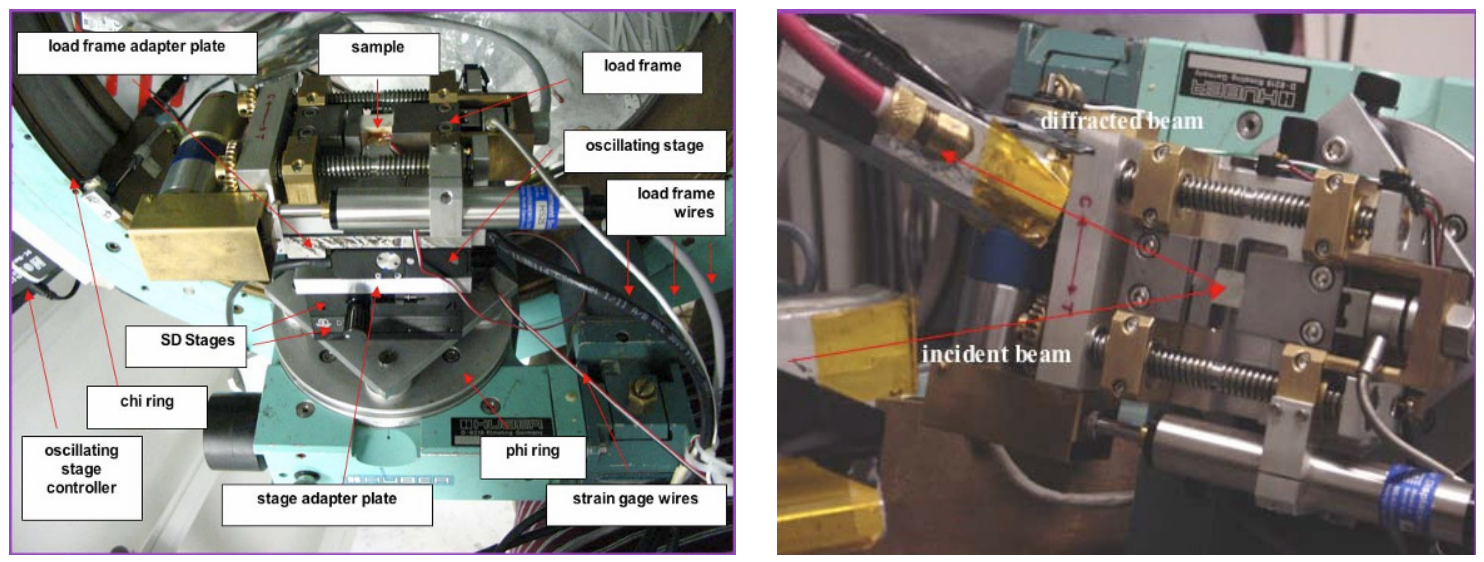

Fig. 5-9. Two views of the compression load frame (constant load) mounted on the X14A synchrotron beam line goniometer.

heating and quenching. As a result, it is often assumed in the literature that if the temperature at the tool flank-workpiece interface exceeds the nominal phase transformation temperature for the steel, a white layer forms. However, no attempt has been made to measure the temperatures produced at the tool flank-workpiece interface and correlate it with microstructural evidence of phase transformation.

A researcher from Georgia Tech visited the RSUC to determine the presence or absence of retained austenite phase within white layer (Fig. 5-10). Retained austenite was observed as a function of both tool speed and wear of tool flank. Generally, the retained austenite increased with tool speed. The data shown below suggest a threshold combination of tool speed and flank wear below which austenite forms are not retained. Above the threshold, the data suggest that retained austniteand was effectively independent of flank wear. The presence of retained austenite in the white layer provides an important observation helping to answer the question regarding the phase transformation temperature for white layer formation. 

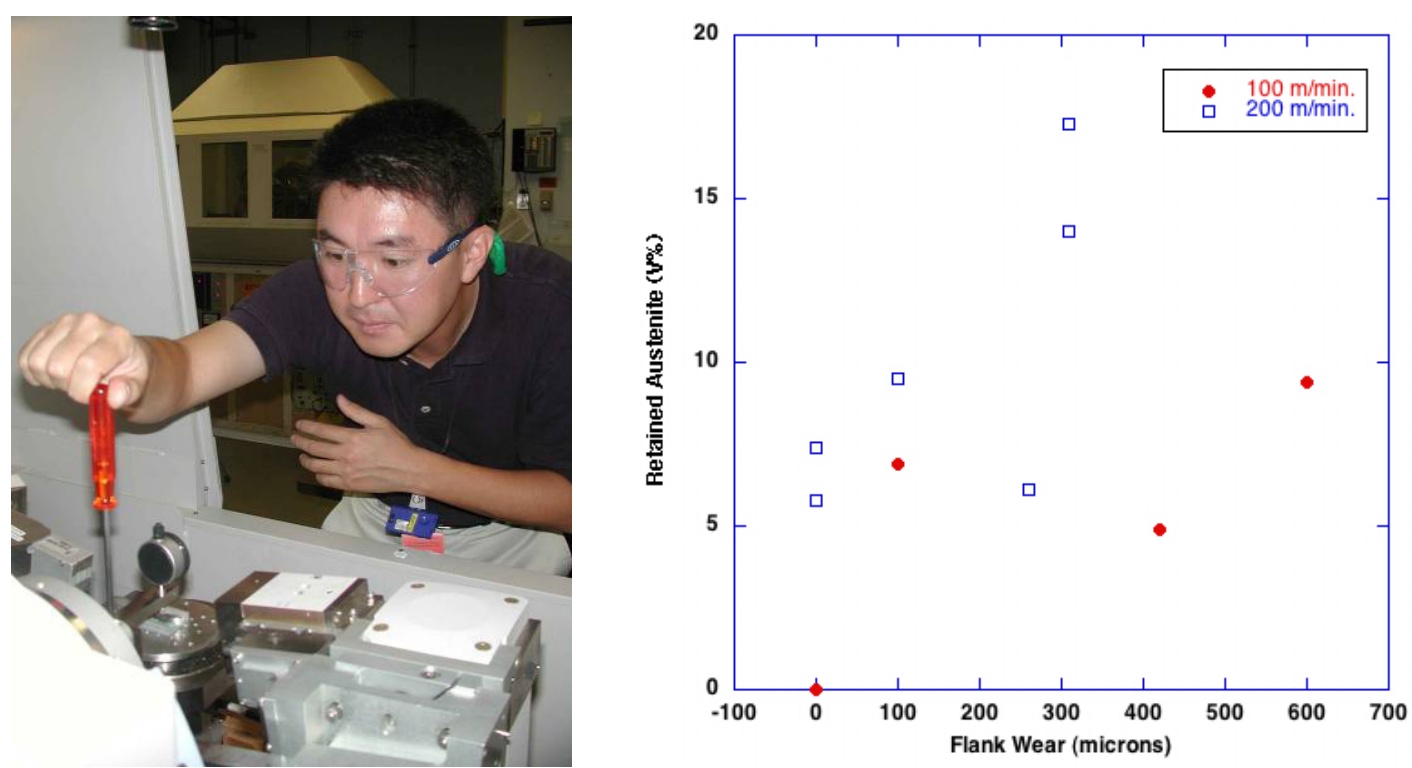

Fig. 5-10. (left) Sangil Han of Georgia Tech, mounting his ring sample to the PANalytical X-ray Diffractometer and (right) retained Austenite as a function of tool flank wear.

\section{The Effect of Overload on the Fatigue Crack Growth Behavior of the 316 Stainless Steel- University of Tennessee}

Collaborators: Y. Sun and P. K. Liaw

HTML: H. Choo and C. R. Hubbard

From a material-development perspective, new materials with a better crack resistance could be designed only after better understanding the damage mechanism. Since the fatigue-crackgrowth behavior is driven predominantly by the crack-tip plasticity, and plastic strains are irreversible, changes in the load patterns result in transient effects that affect fatigue-crackgrowth rates and, hence, the fatigue life. Load-interaction phenomena complicate life predictions, and their understanding remains crucial to crack-growth predictions. Although much attention has been devoted to the overload effect, since its discovery in 1961, the phenomenon is still not fully understood. Reliable methods to predict these transient effects are important.

The commonly documented random loading or transient effect on the fatigue behavior of a material is that of fatigue-crack-growth rate retardation following single or block overloads (Fig. 5-11, inset). After the overload, there is a period of crack-growth retardation that is related to the magnitude and number of overloads.

A single overload was applied during constantload-amplitude fatigue test, and the retardation period was observed (Fig. 5-11). Five

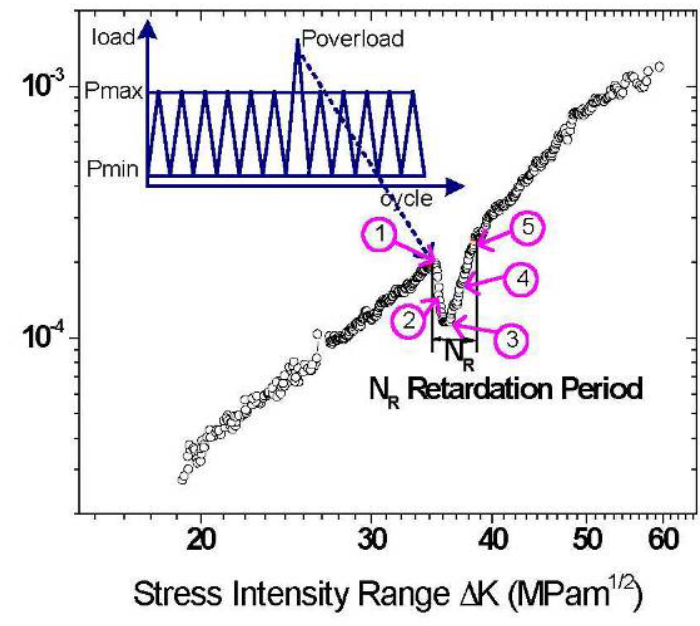

Fig. 5-11. Diagram of the crack growth rate vs stress intensity range. Inset: cyclic fatigue cycles and the single overload. 
specimens with different crack lengths (growing through the retardation period) were prepared. The crack lengths in the five specimens are $15.29 \mathrm{~mm}, 15.6 \mathrm{~mm}, 16.28 \mathrm{~mm}, 17 \mathrm{~mm}$ and $17.92 \mathrm{~mm}$, respectively.

Mapping of strains about the crack tip for the five specimens are shown in Fig. 5-12. The strain profiles as a function of the distance from where the overload was applied show the different strain distributions for five samples. Specimens 1, 2, and 3 (when the crack-growth rate decreases) have the similar strain profiles. The values of the compressive strains near the crack tip are approximately equal to one another for specimens 1,2 , and 3 . Specimens 4 and 5 are specimens in which the crack-growth rate increases; they have similar strain profiles but different from those of samples 1,2, and 3. The compressive strains in specimens 4 and 5 are less than those of the first three specimens. The possible reason for the difference in strain distributions between specimens 1, 2, and 3 and specimens 4 and 5 is that the plastic zone caused by overload is perturbed by the plastic zone caused by fatigue test. Overload induces a large plastic deformation and causes a greater plastic zone. As the crack grew from $15.29 \mathrm{~mm}$ to $16.28 \mathrm{~mm}$, the plastic zone produced by the regular fatigue test after overload had not grown out of the large plastic zone caused by overload. After the crack grew to $16.28 \mathrm{~mm}$, a new plastic zone began to grow out of the large plastic zone, the compressive strain ahead of the crack tip decreased and the crack-growth rate began to increase.

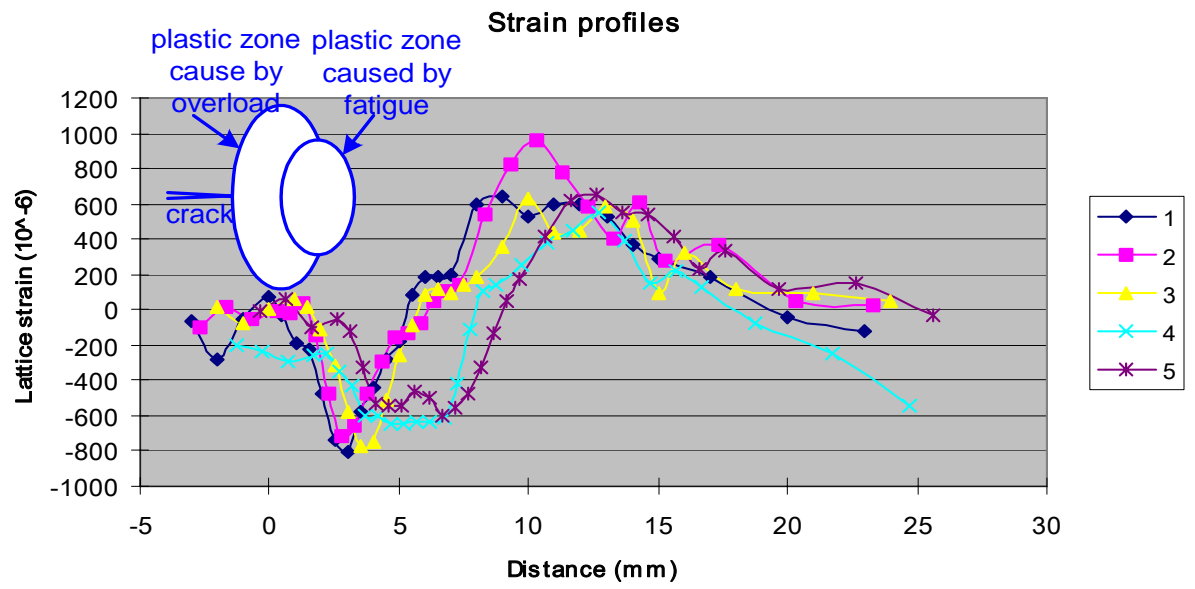

Fig. 5-12. Neutron strain mapping results for the five samples subjected to cyclic fatigue.

\section{Neutron Diffraction Residual Stresses Mapping of Cylinder Liners in Automobile Engine Block-Third Wave Systems, Inc.}

Collaborators: T. Marusich, R. J. McDaniel, and W. Warp

HTML: F. Tang and C.R. Hubbard

Cast iron cylinders are used as liners for the piston cylinders in aluminum automobile engine blocks. Thin-walled iron cylinders are cast, and the outer diameter is machined. The state of residual stress that exists as a result of the casting and machining processes can cause part distortion. Third Wave Systems, Inc., is investigating the cause and magnitude of the residual stress and is developing the capability to model the stress by using its AdvantEdge ${ }^{\mathrm{TM}}$ software in order to reduce part distortion, increase machine tool life, and decrease scrap rates. 
To properly simulate the forces induced by the machining, the bulk stress through the entire thickness of the cylinder wall before and after machining must be determined. Neutron diffraction stress mapping was used for the measurement of the stresses through the thickness of the cast iron liner blank and at various rotations about the cylinder.

Figure 5-13 shows the as-cast cylinder liner mounted on the NRSF2 in the orientation for hoop strain measurement. The hoop, normal, and axial major strain components were measured in the as-cast cylinder liner tube and for a machined cylinder liner. Strains were then converted to stresses (Fig. 5-14). The stress mapping results show that stress gradients exist through thickness with the largest radial stresses near the ID.

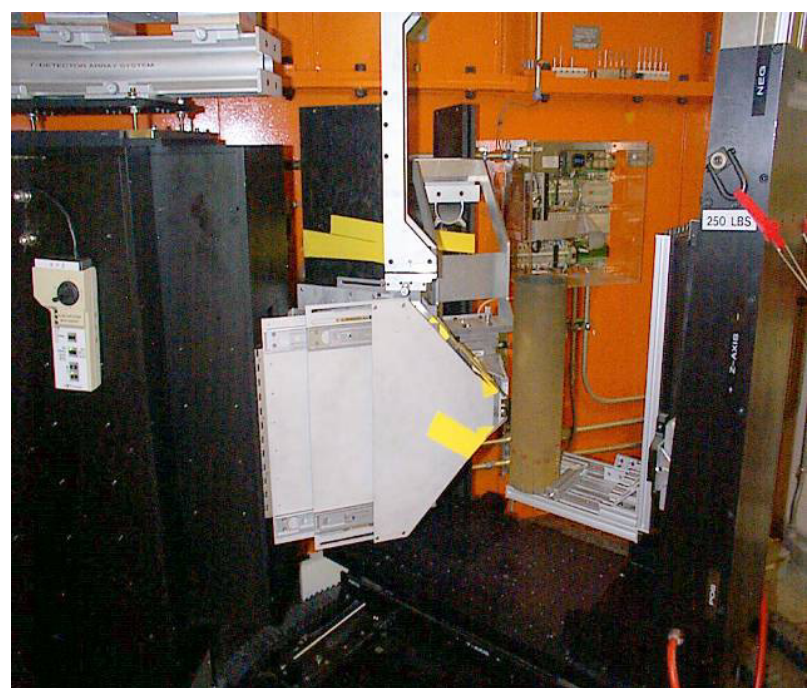

Fig. 5-13. As-cast cylinder liner tube on NRSF2 for stress mapping.

The through-thickness d-spacing changes in two locations in the machined liner show that the machining operation changes the residual stresses in the threaded region compared to an unthreaded region. In this case only the hoop d-spacing was measured as a demonstration of the capabilities of neutron strain mapping to map through the thickness (Fig. 5-15).

\section{The Effect of Welding Process on the Residual Stress Distribution in Welded Cruciform Parts-Caterpillar Technical Center}

Collaborators: Zhishang Yang and Hiroko Kyuba

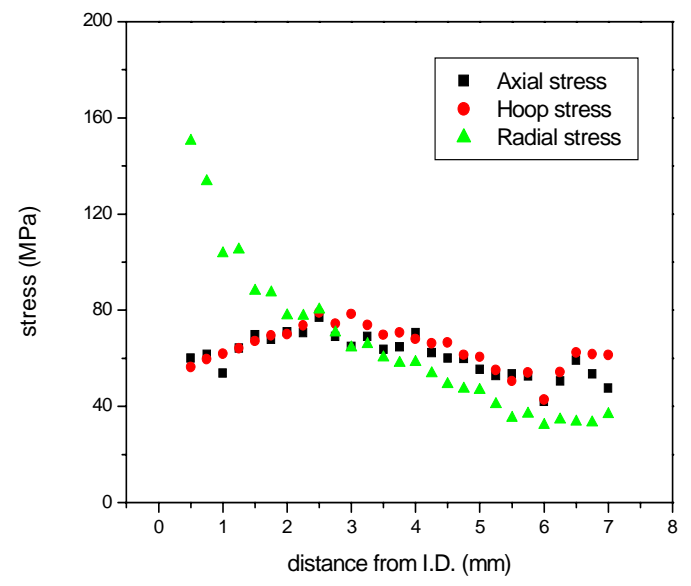

Fig. 5-14. Through-thickness residual stress results from as-cast cylinder liner tubes.

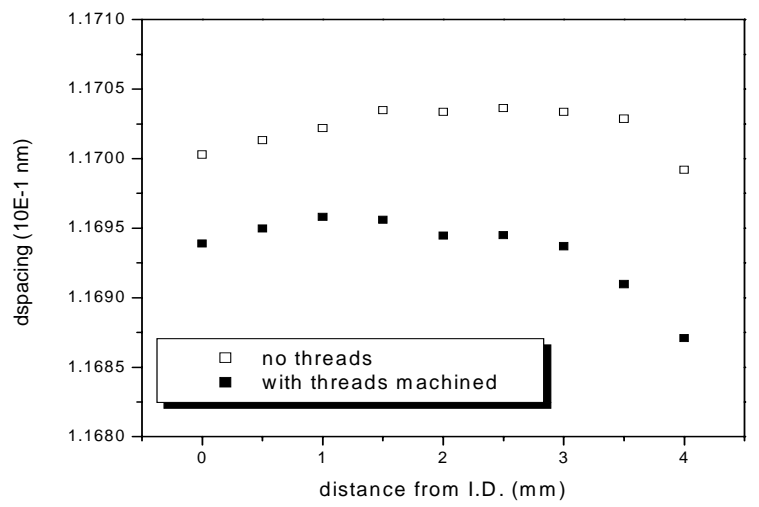

Fig. 5.15. Through-thickness Fe (211) d-spacing in the machined cylinder liner at locations with and without machined threads.

HTML: F. Tang, E. A. Payzant, C. R. Hubbard, K. An, and W. Bailey

Attempts to improve fuel economy in both on-highway and off-highway vehicles are accelerating due to the energy shortage and environmental factors. Designing and producing lighter 
structures for vehicles by using high-strength materials is limited by the low fatigue strength of welded joints. As one of the major technical barriers to developing fatigue-resistant welds, high tensile residual stresses, which accelerate the fatigue crack propagation and reduce weld fatigue life, are usually formed in high-strength steel welds. A systematic approach to improve the fatigue life of a welded joint by ten times and to reduce energy use by $25 \%$ involved developing special welding wires and evaluating the weld process with the goal of introducing compressive residual stress at the weld toe of high-strength steel welds.

Three specimens were welded using conventional and lowtemperature martensite transformation welding wires to produce smooth weld bead shape and compressive weld toe residual stress. Through-

thickness residual stress and surface stress measurements on small cruciform samples cut from large welded specimens

(Fig. 5-16) were used to evaluate the residual stress distribution around the weld toe produced by conventional welding wire and by the special welding wire.
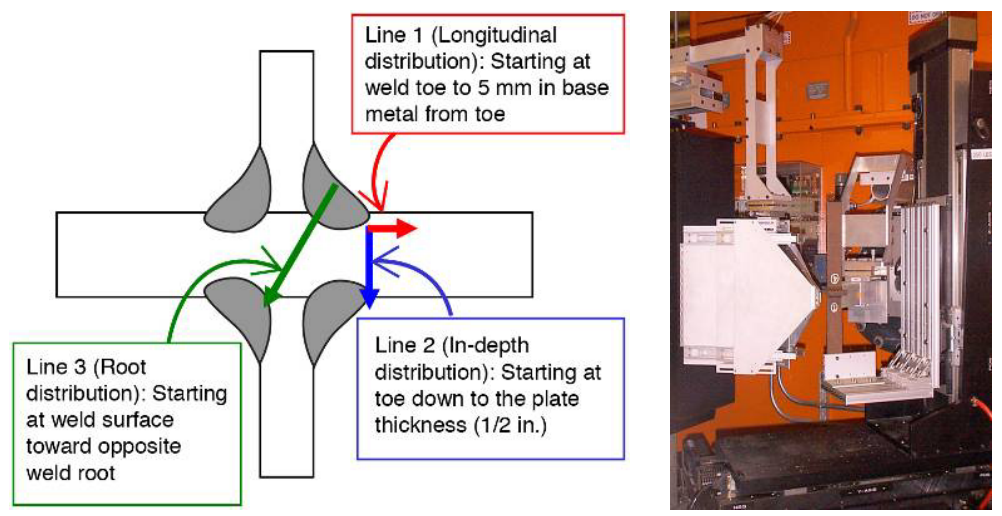

Fig. 5-16. Cross section of cruciform part (left). Welded cruciform specimen mounted on NRSF2 for stress mapping (right).

X-ray diffraction was used to measure Line 1; neutron diffraction was used to measure lines 2 and 3 . The residual stress data along line 2 were used for fatigue life prediction with weld toe failure. The residual stress along line 3 can be used for fatigue life prediction with weld root failure. Neutron strain mapping results along line 2 for three different weld processes are shown in Fig. 5-17. Measured residual stresses for line 2, direction 1, for the welds made using conventional wire and special welding wires, along with the polynomial fitted stress profiles. Surface residual stress data were obtained by averaging extrapolated neutron diffraction stress and X-ray stress.
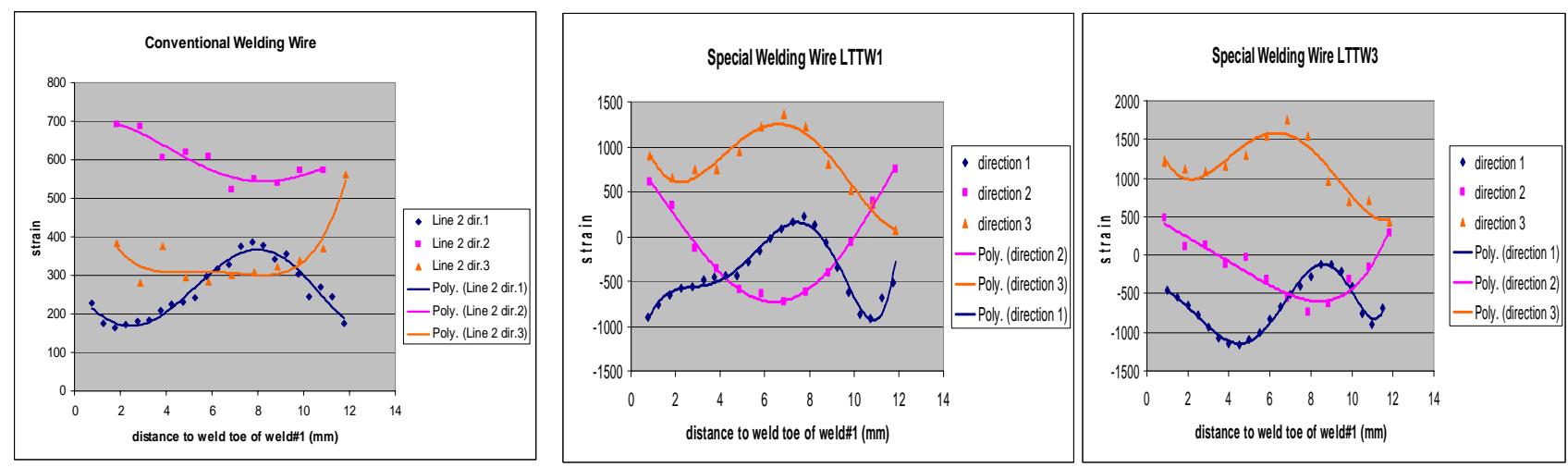

Fig. 5-17. Strains in three orthogonal directions for: (a) conventional welding wire, (b) LTTW 1 wire, and (c) LTTW 3 wire. 
The patterns of the measured residual stresses (Fig. 5-18) on and near the surface for the investigated three types of welded-joints are consistent with those from the simulation (i.e., tensile residual stress at the weld toe with conventional welding wire and compressive residual stress at the weld toe with special welding wires).

The predicted fatigue life using a two-stage crack growth model considering the effect of compressive residual stress with special welding wire welds are in reasonable agreement with the high end of fatigue test results, which show more than 10x in improvement fatigue life for the high-strength steel welded joints.

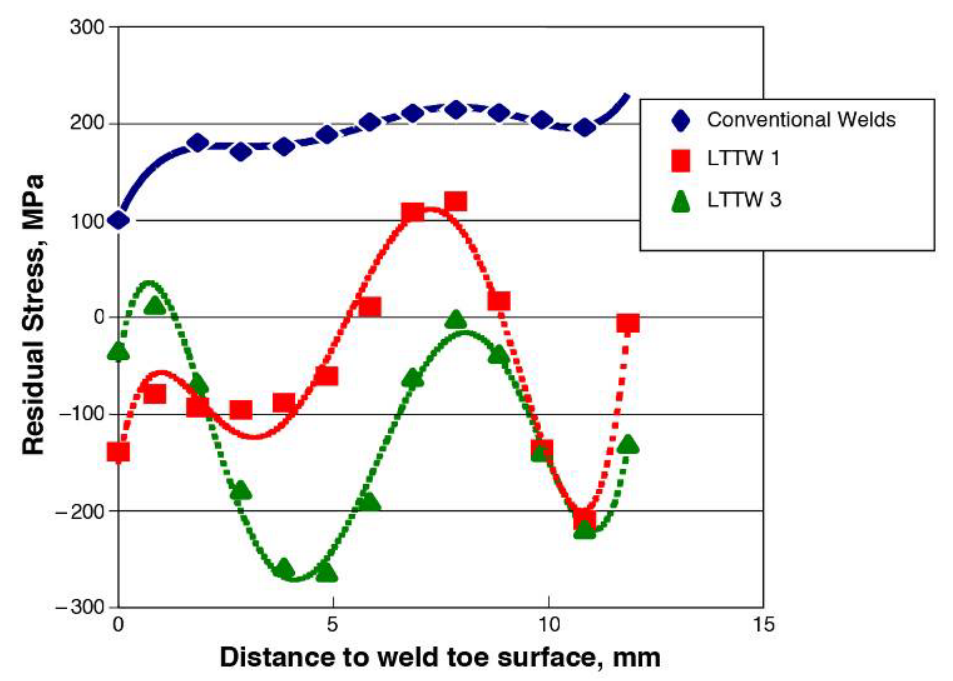

Fig. 5-18. Neutron residual stress results for direction 1 for the three weld processes. 


\title{
6. THERMOGRAPHY AND THERMOPHYSICAL PROPERTIES USER CENTER (TTPUC)
}

\author{
User Center Members \\ Ralph B. Dinwiddie, Leader \\ Geneva N. Worley, Secretary \\ Wallace D. Porter \\ Hsin Wang
}

The TTPUC is dedicated to measuring thermophysical properties as a function of temperature and correlating these properties with the processing, microstructure, and performance of materials. Specifically, TTPUC staff work with users to determine thermophysical properties such as thermal diffusivity, thermal conductivity, electrical resistivity, Seebeck coefficient, specific heat, thermal expansion, and total hemispherical emittance. They also work with users to characterize the thermal stability, high-temperature reactions and compatibility, and hightemperature oxidation and corrosion properties of materials. The materials studied include structural ceramics; thermoelectrics, engineering alloys; ceramic, carbon, and metal matrix composites; ceramic precursors; superconducting materials; carbon materials; powders; and foams.

The TTPUC continues to develop capabilities in the field of thermography [infrared (IR) imaging] and sensing using focal plane array IR cameras and fast, single-point IR detectors coupled with IR fibers and light pipes. These capabilities have been demonstrated for a wide variety of materials processes, in-service performance characterizations, temperature mapping, and nondestructive evaluation (NDE) inspections.

\section{TTPUC Instruments}

- Laser flash thermal diffusivity system (cryogenic temperatures to $2500^{\circ} \mathrm{C}$ )

- Xenon flash thermal diffusivity system (room temperature)

- Hot disk thermal constants analyzer (cryogenic temperatures to $750^{\circ} \mathrm{C}$ )

- Three-omega thermal diffusivity system (room temperature to $450^{\circ} \mathrm{C}$ )

- Radiance-HSX IR camera (3-5 microns)

- Alpha TE cooled IR camera (7.5-13 microns)

- Omega uncooled IR camera (7.5-13 microns)

- Phoenix MWIR camera (1.5-5 microns)

- Phoenix NIR camera (0.9-1.7 microns)

- Hyperspectral imaging lens (3-5 microns)

- IR microscope (3-5 microns)

- High-speed two-color single-point IR detectors (100 kHz)

- ThermoSonix instrument for nondestructive evaluations

- Netzsch differential scanning calorimeter (room temperature to $1600^{\circ} \mathrm{C}$ )

- Dual-push-rod dilatometer (cryogenic temperatures to $1600^{\circ} \mathrm{C}$ )

- Simultaneous thermal analyzer (room temperature to $1500^{\circ} \mathrm{C}$ )

- Chan large sample TG analysis (room temperature to $1700^{\circ} \mathrm{C}$ )

- total hemispherical emittance $\left(100\right.$ to $\left.1400^{\circ} \mathrm{C}\right)$

- Electrical resistivity (room temperature to $1400^{\circ} \mathrm{C}$ ) 
- Seebeck coefficient (room temperature to $800^{\circ} \mathrm{C}$ )

- Visible light spectrometer for reflectance and transmittance studies.

- Near IR spectrometer (0.9-2.6 microns)

\section{Selected Highlights}

\section{TTPUC Staff Visited Ford Chicago Assembly Plant}

Industrial Collaborator: Bill Charron

HTML: Dr. Hsin Wang

HTML staff visited the Ford Chicago Assembly Plant in December 2004 (Fig. 6-1). The purpose was to assess the possibility of implementing the IR weld inspection techniques developed in the ongoing HTML user project. There is no nondestructive inspection technique used in the assembly plant. However, welding defects do occur and the lack of effective inspection can cause major manufacturing problems and slow down the production. HTML staff were led to various locations on the assembly line and identified places where real-time or post-weld inspections can be conducted. The information collected at the plant will be used to finalize the IR inspection procedure. Inspections on body-in-white vehicles and in-plant visits are planned for 2005.

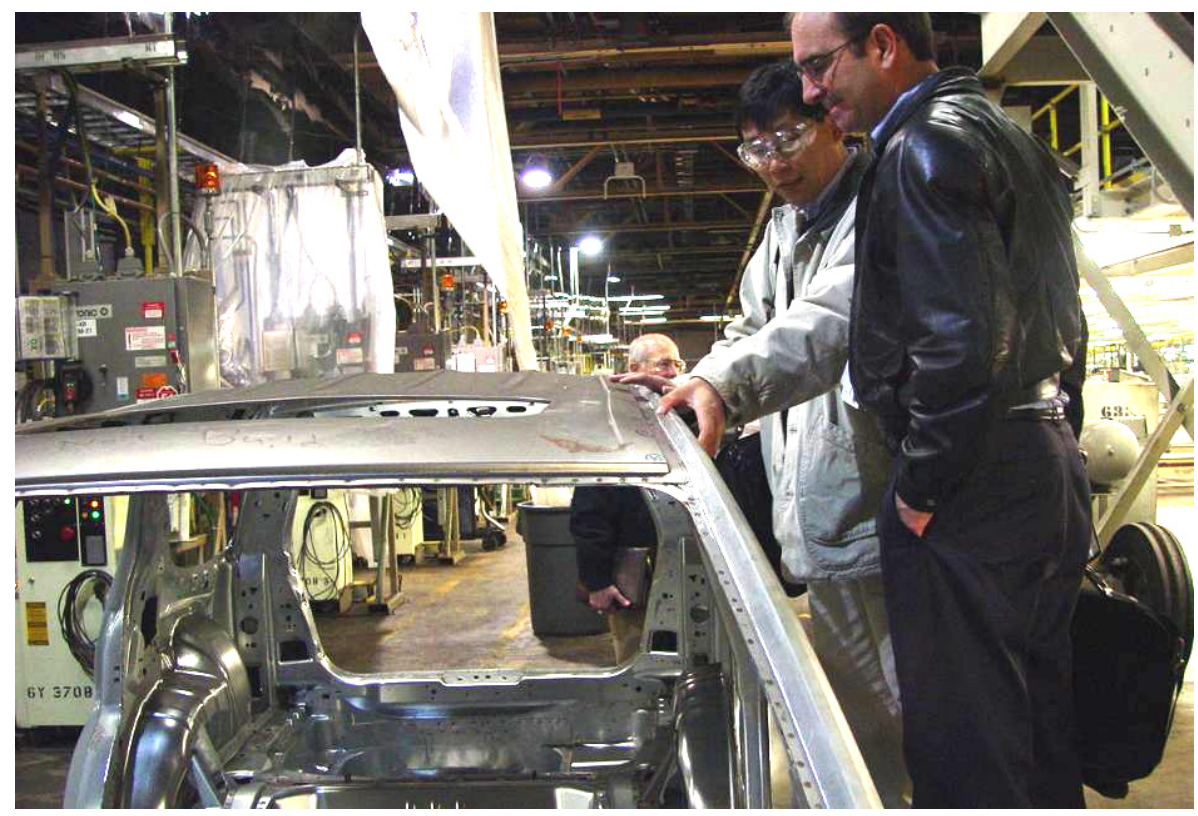

Fig. 6-1. Bill Charron (Ford) looking at laser welds at the Chicago Assembly Plant.

\section{TTPUC to Participate in Thermoelectric Study of Vehicle Waste Heat Recovery \\ Industry Collaborator: Bill Charron}

HTML: Dr. Hsin Wang and Dr. Ralph Dinwiddie

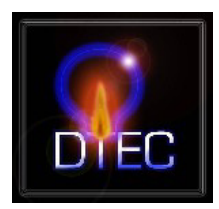

Announced at the Direct Energy Conversion (DTEC04) workshop held in December 12-15, 2004, TTPUC will participate in a DOE-funded project in studies in thermoelectric waste heat recovery devices. The project is led by General Motors. The team includes General Electric, MIT Lincoln Laboratories, RTI, the University of Michigan, the University of South Florida, and others. The major task for TTPUC is to conduct property measurements for the thermoelectric 
materials and to establish a database for material properties. Currently all the properties affecting the thermoelectric figure of merit, thermal conductivity, electrical resistivity, and Seebeck coefficient can be tested at TTPUC. TTPUC staff presented a poster at the workshop where participants were principal investigators from the Defense Advanced Research Projects Agency (DARPA), the Naval Research Laboratory (NRL), the National Aeronautics and Space Administration (NASA), and DOE energy conversion programs.

\section{Researchers from UAB and NASA Marshall Center Studied Thermal Transport Properties of Liquid Semiconductors}

University Collaborator: Prof. Heng Ban

HTML: Dr. Hsin Wang

On an initial visit by two researchers from the University of Alabama at Birmingham (UAB) and one researcher from the NASA Marshall Center, in Huntsville, Alabama, we generated interesting results on thermal conductivity of liquid metals and semiconductors. A quartz cell was designed and prepared at NASA. Since semiconductor melts are transparent in the IR, the study concentrated first on liquid metals. As a first study, mercury was sealed inside the cell and brought to the lab. The cell contact surfaces require a change of boundary conditions in the heat transfer solution. During this project, a general solution for solid-solid, solid-liquid, and solid-air was developed at UAB. This visit was aimed at obtaining experimental data for the three cases at room temperature. Light scattering in the quartz cell wall prevented data collection for the liquid-solid case. Based on hands-on work using the instrument, a new cell design was completed during the visit. It will be tested in future visits.

\section{MIT Studied Thermal Transport Properties of Nanofluids}

\section{MIT: Wesley Williams}

HTML: Dr. Hsin Wang

\section{川iti}

A researcher from the Massachusetts Institute of Technology (MIT) used the Hot Disk system at TTPUC to study the thermal conductivity of nanofluids. The overarching technical objective of this project is to further the understanding of transport phenomena in fluids with small additions $(<2$ vol. \%) of nano-sized $(10-100 \mathrm{~nm})$ particle populations. Such "engineered" fluids (known as nanofluids) are attractive because the presence of the nanoparticles enhances energy transport considerably. As a result, nanofluids have higher thermal conductivity and heat transfer coefficient than their pure base fluid. The potential applications in the nuclear field are numerous. They could also be used to enhance any fluid-based heat transfer equipment (i.e., automotive, computer, and appliance cooling systems or fossil power systems).

The Hot Disk system was recently used to measure thermal conductivity of milk as a function of the fat content. The same $2 \mathrm{~mm}$ raduis Kapton sensor was used in the nanofluid tests. The system was able to generate thermal conductivity of tap and distilled water. When the waterbased nanofluids were tested, significant changes were observed. In the process of the study we also discovered that the simple sensor-in-beaker test is sensitive to temperature variations in the room and contact surfaces. A small temperature disturbance would trigger convective flow in the nanofluids and would affect the consistency of the measurements. A more appropriate sample holder for liquid testing has been designed. The holder will be prepared at MIT. A thermal bath will be prepared at TTPUC. We expect to eliminate the environmental effect and obtain thermal transport properties of the nanofluids more accurately in subsequent visits. 


\section{St. Gobain Conducted Thermal Transport Studies of Zirconia-Based Ceramic}

Industrial Collaborator: Gaëtan Bonhomme

HTML: Mr. Wallace Porter, Dr. Ralph Dinwiddie, and Dr. Hsin Wang

A researcher from Saint-Gobain visited TTPUC to start a study of thermal conductivity of zirconia-based ceramics. The aim of the project is to identify phonon scattering mechanisms from microstructure and compositions. Traditionally, such studies are conducted using thermal barrier coatings. However, studies generated from TTPUC suggested that the effect of porosity strongly affects the results. It becomes very difficult to distinguish the effect of porosity and other phonon scattering mechanisms. To avoid this factor, fully sintered bulk specimens were prepared at Saint-Gobain. The effects of additives and composition were studied using the laser flash and differential scanning calorimetry (DSC) systems. To prevent light leakage at high temperatures, a platinum coating was evaporated onto the sample surfaces. Additional graphite sprays were applied to the sample to enhance surface absorption. Twelve specimens were tested in the initial visit. The results showed consistent trends with sintering conditions, compositions, and microstructures. The full test matrix is scheduled to be examined this summer.

\section{UMR Studied UHTC Using Thermal Diffusivity System}

University Collaborator: Stefanie Marie Ricca

HTML: Dr. Hsin Wang

The University of Missouri, Rolla, (UMR) has been working to develop ultrahigh-temperature ceramic (UHTC) materials for use in future reusable launch vehicles. The current research involves studying the properties of zirconium diboride for these applications and determining the effect that processing has on its microstructure and mechanical and thermal properties. A graduate researcher from UMR visited TTPUC to use the xenon flash thermal diffusivity system to examine their materials. Another purpose of the visit was to learn the basic setup of the xenon flash system. The system at TTPUC was built by staff following the ASTM standards. The UMR researcher was trained on the system and learned of its important issues. A similar system is planned to be built at UMR for fast screening of UHTC materials.

\section{Unifrax Studied High-Temperature Fire-Resistant Materials}

Industry Collaborator: Joseph A. Fernando and Michele Wierzbicki

HTML: Dr. Hsin Wang

Two researchers from Unifrax Corp. visited TTPUC and used the Hot Disk thermal constants analyzer to evaluate thermal conductivity of their thermal insulation materials. The standard method used at the company is time consuming and not reliable. The Hot Disk method provides an alternative way of monitoring the quality and properties of the Unifrax products. A series of thermal insulation materials were evaluated. A special mica sensor was used for hightemperature measurements. Thermal conductivity was tested up to $600^{\circ} \mathrm{C}$. The effects of density, contact pressure, and sample size were studied. The repeatability of the system was evaluated from the measured materials. The visit had provided Unifrax with the necessary information to compare with its existing test method in addition to the needed thermal transport data at high temperatures. 


\section{Southern Illinois University Evaluated Thermal Conductivity of Porous Membranes}

University Collaborator: Professor Punit Kohl

HTML: Dr. Ralph Dinwiddie and Dr. Hsin Wang

A professor from Southern Illinois University brought porous alumina membranes with and without infiltrated metals to TTPUC to evaluate the thermal transport properties of the material (Fig. 6-2). The purpose was to develop an interface heat-spreading material for the microelectronic industry. The Hot Disk system was used for this study. The thin film function of the system, using 25 micron thick Kapton insulation and a stainless steel backing material, was used. Since the thermal conductivity of stainless steel is known, the thermal conductivity of the membrane can be calculated from the interface resistance during normal Hot Disk operation. The method was validated by measuring papers. Several membranes were studied, and the Hot Disk method showed similar thermal conductivity to values reported in the literature. We also found that some membranes were too thin for the method. Thicker specimens, about 100 microns thick, are being prepared at Southern Illinois University for future testing.

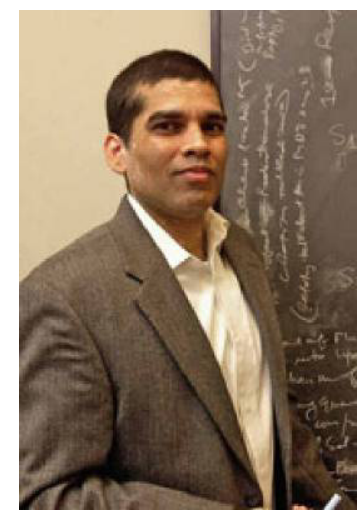

Fig. 6-2. Professor Punit Kohli.

\section{TTPUC Staff Participated in International Thermal Conductivity Conference}

HTML: Dr. Ralph Dinwiddie and Dr. Hsin Wang

Two TTPUC staff traveled to New Brunswick, Canada and attended the twenty-eighth International Thermal Conductivity Conference and the sixteenth International Thermal Expansion Symposium, from June 26 to 29, 2005. Two technical papers were presented by the staff members at the conference and another one as co-author. They also attended the ITCC Board of Governors meeting on June 27. One member, Hsin Wang, was elected the vice president of ITCC Inc. The TTPUC staff members have been instrumental in organizing this biannual conference. They have provided assistance to the current host and aided in selection of the next conference site in 2007 . They also chaired plenary sessions and introduced the keynote speakers at the meeting. The strong presence of TTPUC staff is important to keep ORNL as one of the leading organizations in the area of thermophysical properties measurements.

\section{TTPUC Staff Conducted Off-Site Weld Inspection at the Ford Chicago Assembly Plant}

Industry Collaborator: Bill A. Charron

HTML: Dr. Hsin Wang

During a recent visit to the Ford Chicago Assembly Plant, a TTPUC staff member brought the infrared imaging system and worked with engineers and researchers at Ford to seek solutions to nondestructive weld inspection. Manufacturing the newly launched Ford Five Hundred sedans and Freestyle wagons, the Chicago Assembly Plant is seeking solutions to adequately inspecting the thousands of welds in the vehicle body structure (Fig. 6-3). Currently, laborintensive manual teardown inspection is performed every shift to determine weld quality. A reliable nondestructive evaluation technique can be beneficial to improving inspection reliability and efficiency.

The IR imaging system was set up at an inspection station without interfering with the flow of the assembly line. Laser welds of the roof ditch area and resistance spot welds in the door area were inspected. The IR technique was able to identify weld discrepancies that occurred during 

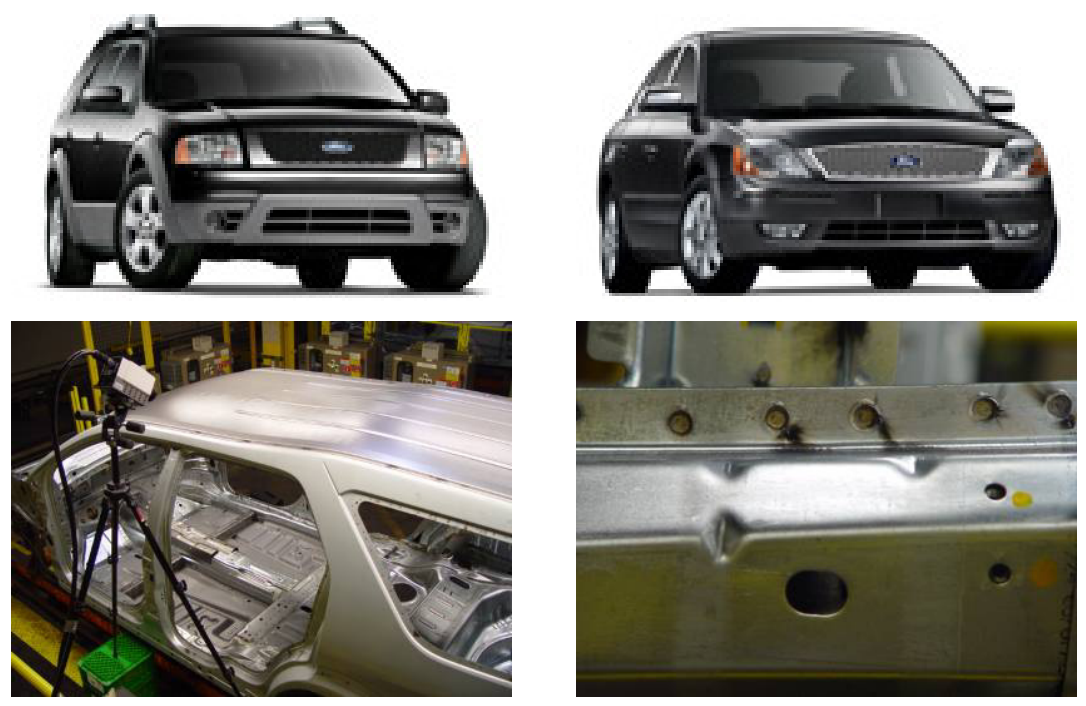

Fig. 6-3. Vehicles produced at the Ford Chicago Assembly Plant. Lower left: laser inspection. Lower right, resistance spot weld inspection.

production. The in-plant visit provided valuable information to the researchers to adapt the technique to the real production environment. Methods to improve IR signal and to process images for fast on-line feedback have been suggested. As a result of the visit, a body-in-white vehicle was shipped to HTML in October 2005 for further study. The offsite visit to the Chicago plant was also sponsored partly by the DOE Office of Energy Efficiency and Renewable Energy FreedomCar Lightweighting Materials Program.

\section{GM R\&D Center Performed High-Temperature Characterization of Thermoelectric Materials}

Industrial Collaborator: Jihui Yang

HTML: Dr. Hsin Wang

A researcher from General Motors (GM) R\&D Center visited TTPUC as an HTML user and to kick off the EERE waste heat recovery program. The HTML user project was aimed at measuring high-temperature thermal transport properties of bulk thermoelectric materials for power generation and application in light trucks (Fig. 6-4.).
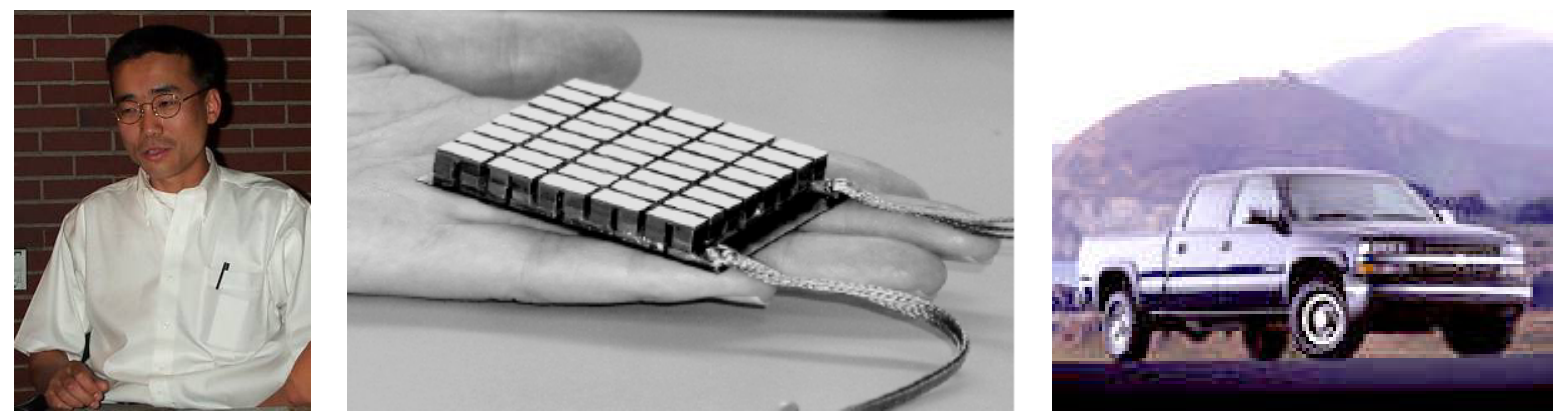

Fig. 6-4. Dr. J. Yang, a GM researcher, visited HTML to test thermoelectric materials for GM light trucks. 
Most thermoelectric characterizations were conducted at room temperature and below. For automotive applications, properties at elevated temperatures need to be obtained. The project at TTPUC was aimed at evaluating bulk thermoelectric specimens (both commercially available and prepared at GM). Room-temperature thermal diffusivity was first measured using the xenon flash system. Cryogenic furnace from $-150^{\circ} \mathrm{C}$ to $50^{\circ} \mathrm{C}$ was used to evaluate the results obtained by a physical properties measurement system at GM. High temperature testing was conducted in the aluminum furnace up to $525^{\circ} \mathrm{C}$ in the range of auto exhaust temperature.

Through the EERE waste heat recovery program TTPUC has planned to add high-temperature Seebeck coefficient and electrical resistivity measurement capabilities in FY 2006. The system will be delivered in October 2005 and ready for users within a month. One of the important features is that the same disk-shaped sample can be used for thermal diffusivity, thermopower, and electrical resistivity measurements.

\section{State University of New York at Stony Brook Started Studies of Thermal Barrier Coating at TTPUC}

$$
\text { University Collaborators: Weiguang Chi, Yang Tan, and Sanjay Sampath }
$$

HTML: Hsin Wang

Two graduate researchers from State University of New York at Stony Brook (Fig. 6-5) visited TTPUC to study the relationship between the microstructure and thermal transport properties of plasma-sprayed thermal barrier coatings (TBCs). As part of the research project at the Center for Thermal Spray Research (CTSR) under the direction of Dr. Sanjay Sampath, the microstructures of a series of TBCs have been carefully characterized. These specimens were tested at Stony Brook at room temperature using a Holometrix room-temperature laser flash system. The main purpose of HTML visit was to expand the temperature range to TBC application limit of $1400^{\circ} \mathrm{C}$.
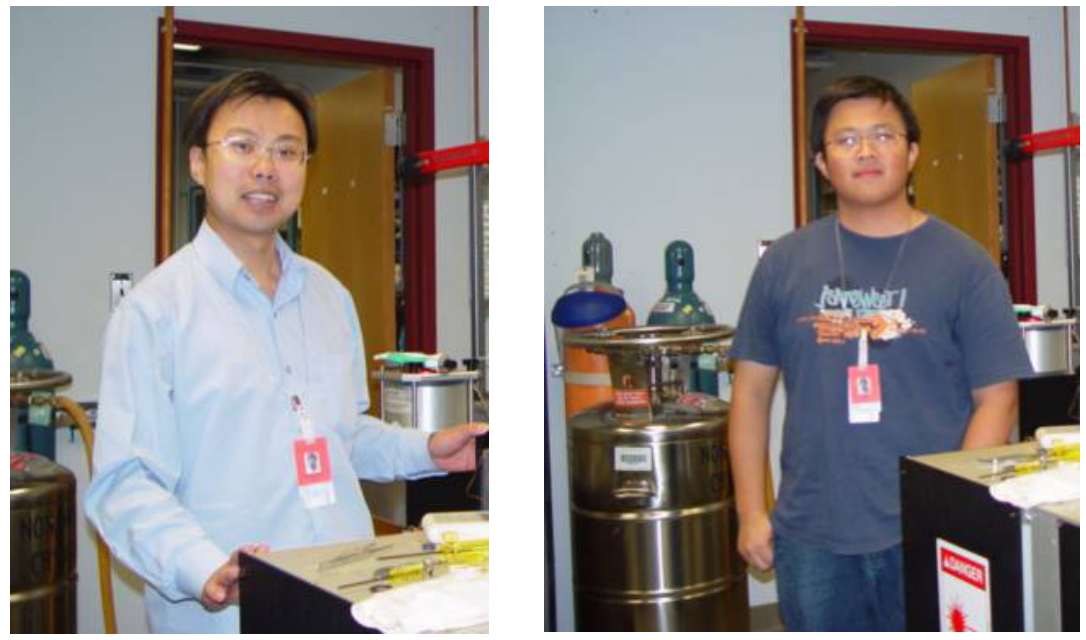

Fig. 6-5. W. Chi and Yang Tan, researchers from the State University of New York at Stony Brook.

During the one-week visit, more than 60 specimens were tested with the room-temperature xenon flash system. The results were consistent with the results obtained at Stony Brook. Thirty TBCs were tested at elevated temperatures using the Anter laser flash system. The results were compared with the existing TBCs database at TTPUC and with microstructure analysis performed at CTSR. A follow-up visit in planned in the fall of 2005 to complete the study. 



\section{STANDARD NONPROPRIETARY USER AGREEMENTS}

The next several pages comprise a listing of U.S. companies, government and other facilities, and universities that have entered into standard nonproprietary user agreements with the HTML. The list includes 427 companies, 20 government and other facilities, and 175 universities. 



\section{U.S. INDUSTRY—427}

\section{Alabama}

Citation Corp. (Birmingham)

Foseco Morval (Bessemer)

IPSCO Steel, Inc. (Axis)

Monarch Tile, Inc. (Florence)

United Defense LP (Anniston)

\section{Arizona}

Advanced Ceramics Research (Tucson)

Global Building Systems, Inc. (Prescott)

Materials Focus, Inc. (Tucson)

MER Corp. (Tucson)

Motorola (Tempe)

RASTRA of the Americas (Litchfield Park)

Tri-Chord Steel Systems, Inc. (Phoenix)

\section{Arkansas}

Domtar Incorporated (Ashdown)

MacSteel (Fort Smith)

NanoMech (Fayetteville)

\section{California}

Abbotly Technologies, Inc. (Upland)

Allied Signal, Inc., Ceramic Components (Torrance)

Alzeta Corp. (Santa Clara)

Amercom, Inc. (Chatsworth)

CERCOM, Inc. (Vista)

Enalysys Corporation (Calexico)

Ensci, Inc. (Pismo Beach)

FMC Corp. (Santa Clara)

IBM Almaden Research Center (San José)

James Hardee Building Products (Fontana)

Lockheed Martin Skunk Works (Palmdale)

Membrane Technology Research (Menlo Park)

M. J. Schiff \& Associates, Inc. (Upland)

Northrop Corp. (Pico Rivers)

Nuclear and Aerospace Materials Corp. (Poway)

Rohr, Inc. (Chula Vista)

Solar Turbines, Inc. (San Diego)

SRI International (Menlo Park)

Sullivan Mining Corp. (San Diego)

Sunstrand Corp. (San Diego)

Ultramet (Pacoima)

X-Ray Instrumentation Associates

(Mountain View)

\section{Colorado}

Coors Ceramics Co. (Golden)

Golden Technologies Co. (Golden)

Johns Manville (Littleton)

Material Physics Research (Highlands Ranch)

NA Technologies (Golden)

Protecto Wrap Co. (Denver)

Quantum Peripherals (Louisville)

Schuller International, Inc. (Littleton)

TDA Research, Inc. (Wheat Ridge)

\section{Connecticut}

ABB C-E Services, Inc. (Windsor)

Plasma Coatings, Inc. (Waterbury)

Praxair, Inc. (Danbury)

Steven Winter Associates, Inc. (Norwalk)

Torrington Co. (Torrington)

United Technologies Pratt and Whitney (East

Hartford)

\section{Delaware}

E. I. du Pont de Nemours (Wilmington)

E. I. du Pont de Nemours (Fluorochemicals) (Wilmington)

Guidance and Control Systems-Litton Systems, Inc. (Litton)

Rodel, Inc. (Newark)

\section{Florida}

American Boarts Crushing Co., Inc. (Boca Raton)

American Diesel \& Gas, Inc. (Boca Raton)

Constellation Technology Corp. (Largo)

Elliott Energy Systems (Stuart)

Florida Solar Energy Center (Cape Canaveral)

James Brakebill (Destin)

Lennar Family of Builders (Miami)

Magnum Technology (Tampa)

Metamic, LLC (Lakeland)

Pratt and Whitney (West Palm Beach)

SEMCO, Inc. (Marietta)

Siemens Westinghouse Power Corp. (Orlando) 


\section{Georgia}

Advanced Engineered Materials, LLC

(Woodstock)

Amercord, Inc. (Lumber City)

Ceradyne, Inc. (Scottdale)

Component Composite Coatings Int'I, LLC

(Roswell)

Ionic Atlanta, Inc. (Atlanta)

Microcoating Technologies (Chamblee)

Motorola Energy Systems Group

(Lawrenceville)

RCF Seals (Vidalia)

Rolls Royce, Inc. (Atlanta)

Thermal Ceramics (Augusta)

Universal Alloy Corporation (Canton)

\section{Idaho}

D8, Inc. (Potlatch)

A. Finkl \& Sons (Chicago)

\section{Illinois}

Adtech Nepth Inc. (Oak Park)

Alloy Engineering and Casting Co.

(Champagne)

Applied Thin Films, Inc. (Evanston)

Belcan Corp. (Peoria)

Caterpillar, Inc., Technology Center (Peoria)

Deere \& Co. (Moline)

Insulating Concrete Form Association

(Glenview)

International Titanium Powder, LLC (Lockport)

Marjan, Inc. (Montgomery)

Metal Construction Association (Glenview)

Scot Forge (Spring Grove)

UOP, LLC (Des Plaines)

Wagner Castings Co. (Decatur)

\section{Indiana}

Allison Engine Co. (Indianapolis)

Cummins Engine Co., Inc. (Columbia)

Dana Corp. (Richmond)

Firestone Building Products Co. (Carmel)

GM Corp./Delco Remy Division (Anderson)

Haynes International (Kokomo)

Pyromation, Inc. (Fort Wayne)

Symmetry Medical, Inc. (Warsaw)

\section{Kentucky}

ARCO Aluminum, Inc. (Louisville)

CC Metals and Alloys, Inc. (Calvert)

Florida Tile Industries (Lawrenceburg)

Lexmark (Lexington)

Logan Aluminum (Russellville)

Machining Research Inc. (Florence)

Secat, Inc. (Lexington)

Stoody Co. (Bowling Green)

Louisiana

Lockheed Martin Michoud Space Systems

(New Orleans)

Busek Co., Inc. (Natick)

\section{Maine}

Surmet Corp. (Burlington)

Uniform Metal Technologies, LLC (Watertown)

\section{Maryland}

Gamma Engineering Corp. (Rockville)

Hilcoit Corp. (Upper Marlboro)

Krispin Technologies, Inc. (Rockville)

RCMA (Rockville)

Refractory Composites, Inc. (Glen Burnie)

W. R. Grace and Co-Conn (Columbia)

\section{Massachusetts}

American Superconductor Corp. (Watertown)

Brigham and Women's Hospital (Boston)

Ceramics Process Systems Corp. (Milford)

Chand Kare Technical Ceramics (Worcester)

Chand Metallurgical (Worcester)

Dynamet Technology (Burlington)

Engineered Material Solutions (Attleboro)

Foster Miller, Inc. (Waltham)

GTE Laboratories, Inc. (Waltham)

Hydrogen Microplasmatron Technologies, LLC (Cambridge)

Hyperion Catalysis International, Inc.

(Cambridge)

JPS Elastomerics Corp. (Holyoke)

Norton/TRW Ceramics (Northboro)

Osram Sylvania (Beverly)

Philips Analytical, Inc. (Natick)

Refractory Testing Associates (Chestnut Hill)

Rohm and Haas (Woburn)

Saint-Gobain Norton (Northboro)

Sarnafil, Inc. (Canton)

ZS Genetics (North Reading) 
Acceledyne (Wixom)

\section{Michigan}

A.E.T. Integration (Troy)

AmCast Automotive (Southfield)

Bosch Braking Systems (Farmington Hills)

Chrysler Corp. (Highland Park)

Delphi Corp. (Brighton)

Detroit Diesel Corp. (Detroit)

Dow Chemical Co. (Midland)

Dow Corning Corp. (Midland)

Duro-Last Roofing, Inc. (Saginaw)

Eaton Corp. (Southfield)

Energy Conversion Devices, Inc. (Troy)

Ford Motor Co. (Ann Arbor)

GM Powertrain Group (Pontiac)

GM R\&D Center (Warren)

GS Engineering (Houghton)

Hoskins Manufacturing Co. (Hamburg)

Howmet (Whitewall)

Inductoheat (Madison Heights)

Modern Alloying Technologies, LLC (West Bloomfield)

Omega Castings (Battle Creek)

Parker Abex NWL (Kalamazoo)

Tenneco Automotive (Glass Lake)

Thixomat (Ann Arbor)

Valenite, Inc. (Troy)

Visteon Corp. (Allen Park)

W. H. Porter, Inc. (Holland)

3M (St. Paul)

Minnesota

Data Machine (St. Paul)

FMC Naval Systems Division (Minneapolis)

H. B. Fuller Co. (Vadnais Heights)

Phygen, Inc. (Minneapolis)

Potlatch Corporation (Bemidji)

Seagate Technology (Minneapolis)

Third Wave Systems (Minneapolis)

\section{Mississippi}

Alpha Optical Systems (Ocean Springs)

Richard Knof McMullan (Decatur)

\section{Missouri}

Deloro Stellite Group, Ltd. (St. Louis)

McDonnell Douglas Aerospace (St. Louis)

MTI-Emory Ford (St. Louis)

SB\&TD Business Systems (Lancaster)

Smith, Bucklin \& Associates, LLC (St. Louis)

Stellite Coatings (St. Louis)

\section{Montana}

Anaconda Foundry Fabrication Co., Inc.

(Anaconda)

Columbia Falls Aluminum Co. (Columbia Falls)

FLUENT, Inc. (Lebanon)

\section{New Hampshire}

Metal Casting Technology, Inc. (Milford)

Miniature Precision Bearings (Keene)

\section{New Jersey}

AcuPowder TN, LLC (Union)

ARDE, Inc. (Norwood)

BASF Corp. (Mount Olive)

Ceramic Magnetics, Inc. (Fairfield)

Certech, Inc. (Wood Ridge)

Engelhard Corp. (Edison)

INRAD, Inc. (Northvale)

International Paper (Princeton)

Lucent Technologies (Murray Hill)

Material Technologies, Inc. (Shrewsbury)

Nanopowder Enterprises, Inc. (Piscataway)

NEC Research Institute, Inc. (Princeton)

Phone-Poulenc, Inc. (Cranbury)

Stryker Howmedica Osteonics (Rutherford)

New Mexico

Eberline Instruments (Santa Fe)

Environmental Technology \& Education Center (Albuquerque)

TPL, Inc. (Albuquerque)

New York

Advanced Refractory Technical, Inc. (Buffalo)

AKZO Nobel Chemicals, Inc. (Dobbs Ferry)

Applied Nano Metrics, Inc. (Stormville)

Carborundum Co. (Niagara Falls)

CDH Energy Corp. (Cazenovia)

CMP Industries, Inc. (Albany)

Corning Inc. (Corning)

Eastman Kodak Co. (Rochester)

GE Global Research (Niskayuna)

General Electric Co. (Schenectady)

Gray-Syracuse, Inc. (Chittenanog)

Monofrax, Inc. (Falconer)

MRC, Division of Praxair Surface Technologies

(Orangeburg)

ReMaxCo Technologies, Inc. (Kenmore)

Starfire Systems, Inc. (Watervliet)

Sulzer Metco, Inc. (Westbury)

T. J. Watson Research Center (Yorktown Heights)

U. K. Software Services, Inc. (Grand Island) 
Unifrax Corp. (Niagra Falls)

X-Ray Optical Systems, Inc. (Albany)

\section{North Carolina}

Advanced Energy (Raleigh)

Alflex Corp. (Battleboro)

ALLVAC (Monroe)

Cree Research, Inc. (Durham)

Magnequench Technical Center (Research Triangle Park)

MetCon (Forest City)

MicroMet Technology, Inc. (Matthews)

Porvair Fuel Cell Technology (Hendersonville)

Richard Childress Racing (Welcome)

Selee Corp. (Hendersonville)

Syngenta Agribusiness Biotechnology Research (Research Triangle Park)

Teledyne Allvac (Monroe)

\section{Ohio}

Advanced Ceramics Corp. (Lakewood)

Advanced Computational and Engineering Services (Gahanna)

Bicron-NE (Solon)

Cincinnati Machine Co. (Cincinnati)

Commonwealth Aluminum (Uhrichsville)

Deformation Control Technology, Inc. (Cleveland)

Doehler-Jarvis Technologies, Inc. (Toledo)

Energy Industries of Ohio (Independence)

Engineering Mechanics Corp. of Columbus (Columbus)

Equistar Technology Center (Cincinnati)

Fireline TCON, Inc. (Youngstown)

General Electric Aircraft Engines (Cincinnati)

Goodyear Tire and Rubber Co. (Akron)

IAP Research, Inc. (Dayton)

Illinois Tool Works (Troy)

IQ Technologies (Akron)

Lincoln Electric (Cleveland)

LTV Steel Co. (Independence)

MascoTech Forming Technologies (Minerva)

Mead Research (Chillicothe)

MET Group, Inc. (Dayton)

Metal Building Manufacturers Association

(Cleveland)

Milacron, Inc. (Cincinnati)

Owens Corning Technical Center (Granville)

Park-Ohio Transportation Group (Cleveland)

PCC Airfoils, Inc. (Beachwood)

Procter \& Gamble Co. (Cincinnati)

Republic Technologies Int'l (Lorain)
Rhenium Alloys, Inc. (Elyria)

Sandusky Int'l (Sandusky)

The Timken Co. (Canton)

Tosoh SMD, Inc. (Grove City)

Universal Energy Systems, Inc. (Dayton)

Western Environmental Corp. (Franklin)

\section{Oklahoma}

Kelix Energies Corp. (Tulsa)

\section{Pennsylvania}

Advanced Technology Materials, Inc.

(University Park)

AHT, Inc. (Chicora)

Alcoa, Inc. (Alcoa Center)

Alcoa Technical Center (Alcoa Center)

Alvord-Polk, Inc. (Millersburg)

Ametek Specialty Metals (Eighty Four)

Ashe Kahre Consulting (Warrent)

Bethlehem Steel Corp. (Bethlehem)

Calgon Corp. (Pittsburgh)

Carlisle Syntec, Inc. (Carlisle)

Carpenter Technology Corp. (Reading)

Certainteed Corp. (Valley Forge)

Concurrent Technologies, Inc. (Johnstown)

Congoleum (Newton)

Duraloy Technologies, Inc. (Scottdale)

Ellwood Materials Technologies Co.

(Ellwood City)

IBACOS (Pittsburgh)

II-VI Inc. (Saxonburg)

J \& L Specialty Steel (Pittsburgh)

Kennametal, Inc. (Latrobe)

Leroy A. Landers (Philadelphia)

Materials Resources Int'l (North Wales)

National Forge Co. (Irvine)

PPG Industries, Inc. (Pittsburgh)

SCHOTT North America-Regional R\&D

(Duryea)

Synthes Co. (West Chester)

Thermacore, Inc. (Lancaster)

West Homestead Engineering and Machine Co.

(Homestead)

Westinghouse Electric Corp. (Pittsburgh)

\section{Rhode Island}

Dryvit Systems, Inc. (West Warwick)

Quadrax Corp. (Portsmouth)

South Carolina

Spirax Sarco, Inc. (Blythewood) 


\section{South Dakota}

K. O. Lee Co. (Aberdeen)

\section{Tennessee}

Activated Metals \& Chemicals (Sevierville)

American Magnetics, Inc. (Oak Ridge)

American Matrix, Inc. (Knoxville)

American Safety Razor Co. (Knoxville)

Atlantic Research Corp. (Knoxville)

Better Than New, LLC (Chattanooga)

Browne Technology, Inc. (Nashville)

BTR Sealing Systems (Rockford)

Camel Manufacturing Co. (Pioneer)

Carroll Kenneth Johnson (Oak Ridge)

Cavin Consulting Services (Knoxville)

Ceramaspeed, Inc. (Maryville)

Church and Dwight Co., Inc. (Knoxville)

Computational Mechanics Corp. (Knoxville)

CTI, Inc. (Knoxville)

Delta M Corp. (Oak Ridge)

DG Trim Products (Alcoa)

Eagle Racing (Loudon)

Eastman Chemical Co. (Kingsport)

EG\&G ORTEC (Oak Ridge)

EmeraChem (Knoxville)

EPRI PEAC Corp. (Knoxville)

FamFive (Knoxville)

Fast Forward Devices, LLC (Knoxville)

Forged Performance Products (Oak Ridge)

Goal Line Co. (Knoxville)

Heil Trailer International (Chattanooga)

H. R. DeSelm (Knoxville)

HRD, Great Lakes Research Div. (Elizabethton)

IMCO Recycling (Rockwood)

IMTech Co. (Knoxville)

Industrial Ceramic Solutions (Oak Ridge)

Intellutran (Knoxville)

IntraSpec, Inc. (Oak Ridge)

J. A. Martin (Knoxville)

Jeffrey Chain Corp. (Morristown)

Machine and Design Technologies, Inc. (Jonesborough)

MATTEC, LLC (Knoxville)

Metal-Tech of Tennessee, LLC (Newport)

Microbial Insight, Inc. (Knoxville)

Millennium Materials, Inc. (Knoxville)

MINCO Acquisition Co. (Midway)

MMPact, Inc. (Oak Ridge)

MS Technology (Oak Ridge)

Multi Phase Services, Inc. (Knoxville)

Nano Instruments, Inc. (Knoxville)
Noranda Magnesium, Inc. (Franklin)

Oxyrase, Inc. (Knoxville)

Precious Metals Corp. (Sevierville)

Pyrotek, Inc. (Trenton)

Reemay, Inc. (Old Hickory)

Remotec (Oak Ridge)

Ronald K. McConathy (Kingston)

Safety and Ecology Corp. (Knoxville)

SCI-TEC, Inc. (Knoxville)

SENES Oak Ridge, Inc. (Oak Ridge)

Smelter Service Corp. (Mt. Pleasant)

Smith and Nephew (Memphis)

Summit Medical Group, PLLC (Knoxville)

Technology for Energy Corp. (Knoxville)

Tennessee Center for Research and

Development (Knoxville)

Textron Specialty Materials-Div. Avco Corp.

(Nashville)

Third Millennium Technologies, Inc. (Knoxville)

TTE Diecasting (Oak Ridge)

VAMISTOR Corp. (Sevierville)

Viatherm Corp. (Knoxville)

Walford Technologies (Oak Ridge)

William Thomas Pope (Clinton)

Texas

Abbotly Technologies, Inc. (Richardson)

Agriboard Industries (Electra)

CarboMedics, Inc. (Austin)

Dallas Optical Systems, Inc. (Rockwell)

Exxon Research \& Engineering Co. (Annadale)

F. W. Gartner Thermal Spray Co. (Houston)

Ludlum Measurement Inc. (Sweetwater)

Marlow Company (Dallas)

Mogas Industries (Houston)

Payless Insulation Inc. (Houston)

Poco Graphite, Inc. (Decatur)

Robert Hageman (Austin)

SGI Ventures, Inc. (Houston)

Smith International, Inc. (Houston)

Stone \& Webster Engineering Corp. (Houston)

Tycom Corp. (Austin)

\section{Utah}

Advanced Metal Products (West Bountiful)

LOTEC, Inc. (West Valley City)

Mantic Corp. (Salt Lake City) 


\section{Virginia}

B\&W Nuclear Technologies (Lynchburg)

Babcock \& Wilcox/McDermott Technology, Inc. (Lynchburg)

Electronic Development Labs, Inc. (Danville)

E. R. Johnson Associates, Inc. (Fairfax)

Electronic Development Labs, Inc. (Danville)

Energy Recovery, Inc. (Virginia Beach)

HY-Tech Research Corp. (Radford)

Materials Modification, Inc. (Fairfax)

Materials Technologies of Virginia (Blacksburg)

Metalspray North America, LLC (Richmond)

Morgan-McClure Motorsports (Abingdon)

National Electronics Manufacturing Initiative, Inc. (Herndon)

Philip Morris, Inc. (Richmond)

RAND Corp. (Arlington)

Reynolds Metal Co. (Richmond)

Soil and Land Use Technologies (McLean)

Synterials, Inc. (Herndon)

\section{Washington}

Chiroscience R\&D Inc./Darwin Molecular (Bothell)

Galvalume Sheet Producers of North America (Kalama)

Harmonics, Inc. (Seattle)

Kyocera Industrial Ceramics Corp. (Vancouver)

Northwest Numerics and Modeling, Inc. (Seattle)

SIPA (Gig Harbor)

Weyerhaeuser Co. (Tacoma)

\section{West Virginia}

Centurion Aluminum Co. (Ravenwood)

FMW Composite Systems (Bridgeport)

HK Casting, Inc. (Weston)

Huntington Alloys/Special Metals Div.

(Huntington)

INCO Alloys, Inc. (Huntington)

Special Metals Corp. (Huntington)

Weirton Steel Corp. (Weirton)

\section{Wisconsin}

Federal Mogul Power Train Systems

(Manitowoc)

Oshkosh Trucks (Oshkosh)

Tower Automotive (Milwaukee)

Waukesha Electric Systems (Waukesha) 


\section{GOVERNMENT AND OTHER FACILITIES-20}

\section{Alabama}

NASA/Marshall Space Flight Center (Huntsville)

\section{California}

NASA-Jet Propulsion Laboratory (Pasadena)

Space and Naval Warfare Systems Center

(San Diego)

\section{Colorado}

U.S. Bureau of Mines Albany Research Center (Golden)

\section{Florida}

National High Magnetic Field Laboratory (Tallahassee)

\section{Illinois}

Gas Technology Institute (Des Plaines)

National Coil Coating Association (Chicago)

\section{Maryland}

NAHB Research Center (Upper Marlboro)

National Institute of Standards and Technology (Gaithersburg)

U.S. Food and Drug Administration (Rockville)

\section{Massachusetts}

Single Ply Roofing Institute (Needham)

\section{Ohio}

NASA Glenn Research Center (Cleveland)

\section{Virginia}

NASA Langley Research Center (Hampton)

U.S. Army Research Laboratory (Fort Belvoir)

Washington, D.C.

American Iron and Steel Institute

Appliance Industry/Government CFC Replacement Consortium Inc.

Federal Highway Administration, U.S. Department of Transportation

National Highway Traffic Safety Administration Society of the Plastic Industry/Spray

Polyurethane Foam Division

Structural Insulated Panel Association 


\section{UNIVERSITIES-175}

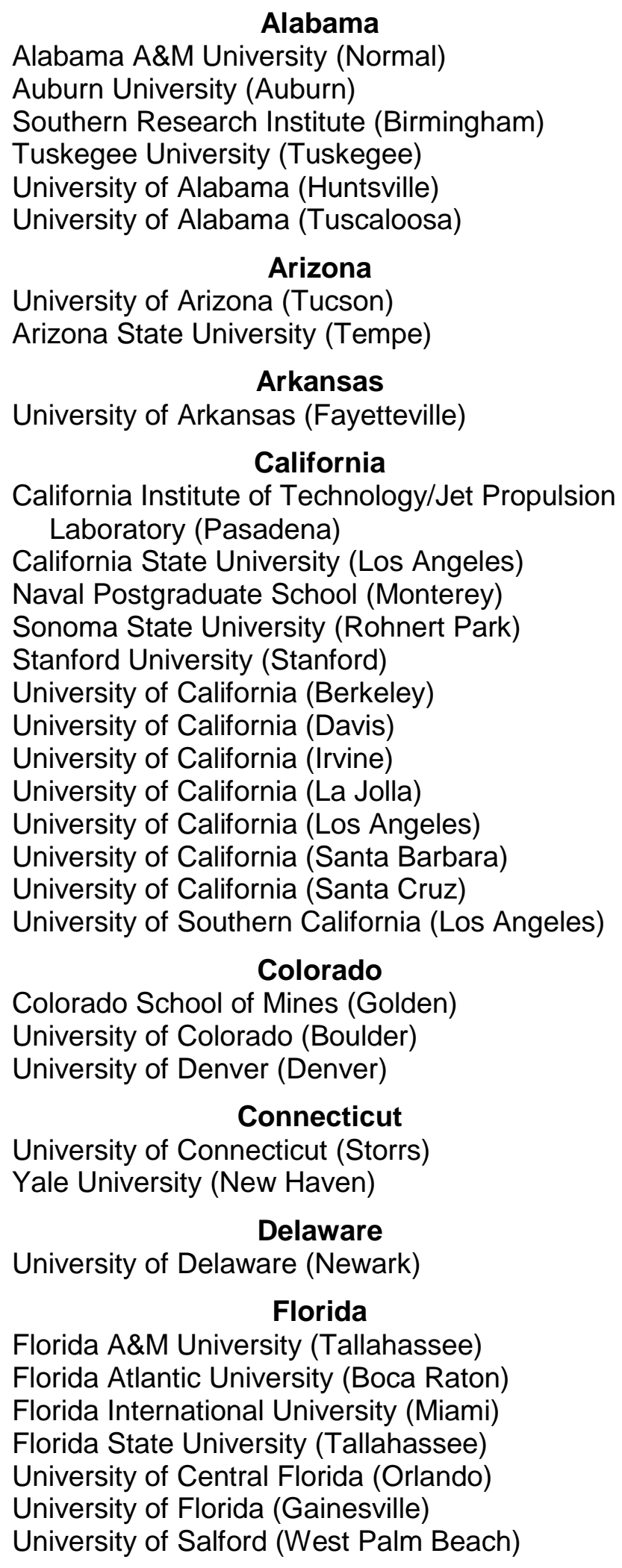

\section{Georgia}

Georgia Institute of Technology (Atlanta) Institute of Paper Science and Technology (Atlanta)

University of Hawaii (Honolulu)

\section{Illinois}

Illinois Institute of Technology (Chicago) Northwestern University (Evanston) Southern Illinois University (Carbondale) University of Illinois (Urbana)

\section{Indiana}

Indiana University (Indianapolis)

Purdue University (West Lafayette)

Purdue University Calumet (Hammond)

University of Notre Dame (Notre Dame)

lowa State University (Ames)

\section{lowa}

Kansas

Kansas State University (Manhattan)

Wichita State University (Wichita)

Berea College (Berea)

\section{Kentucky}

Eastern Kentucky University (Richmond) University of Kentucky (Lexington) University of Louisville (Louisville) Western Kentucky University (Bowling Green)

\section{Louisiana}

Louisiana State University (Baton Rouge)

Southern University (Baton Rouge)

University of New Orleans (New Orleans)

Maine
University of Maine (Orono)
Maryland

Johns Hopkins University (Baltimore)

U.S. Naval Academy (Annapolis)

University of Maryland (College Park)

Boston University (Boston)

Clark University (Worcester)

Harvard University (Cambridge)

Massachusetts Institute of Technology

(Cambridge) 
Mount Holyoke College (South Hadley)

Northeastern University (Boston)

Tufts University (Medford)

University of Massachusetts (Amherst)

University of Massachusetts (Lowell)

Worcester Polytechnic Institute (Worcester)

\section{Michigan}

Michigan State University (East Lansing)

Michigan Technological University (Houghton)

University of Michigan (Ann Arbor)

Wayne State University (Detroit)

Western Michigan University (Kalamazoo)

\section{Minnesota}

University of Minnesota (Minneapolis)

Mississippi
Mississippi College (Clinton)
Mississippi State University (Stark
University of Mississippi (Oxford)
Missouri
Lincoln University (Jefferson City)
University of Missouri (Columbia)
University of Missouri (Rolla)
Washington University (St. Louis)
Montana
University of Montana (Missoula)
Nebraska
University of Nebraska (Lincoln)
Nevada
DRI Institute (Reno)
University of Nevada (Reno)

\section{New Hampshire}

Dartmouth College (Hanover)

\section{New Jersey}

New Jersey Institute of Technology (Newark)

Princeton University (Princeton)

Rutgers University (Piscataway)

Stevens Institute of Technology (Hoboken)

New Mexico

New Mexico Institute of Mining and Technology (Socorro)

New Mexico Tech (Socorro)

New Mexico State University (Las Cruces)

University of New Mexico (Albuquerque)

\section{New York}

Clarkson University (Potsdam)

Columbia University (New York)

Cornell University (Ithaca)

New York State College of Ceramics at Alfred University (Alfred)

Polytechnic University (Brooklyn)

Rensselaer Polytechnic Institute (Troy)

Rochester Institute of Technology (Rochester)

State University of New York (Oswego)

State University of New York at Stony Brook (Stony Brook)

University of Rochester (Rochester)

North Carolina

Appalachian State University (Boone)

Duke University (Durham)

North Carolina Agricultural and Technical State University (Greensboro)

North Carolina State University (Raleigh)

University of North Carolina (Chapel Hill)

University of North Carolina (Charlotte)

\section{North Dakota}

University of North Dakota (Grand Forks)

\section{Ohio}

Case Western Reserve University (Cleveland)

Denison University (Granville)

Edison Welding Institute (Columbus)

John Carroll University (University Heights)

Kent State University (Kent)

Ohio State University (Columbus)

Ohio University (Athens)

University of Akron (Akron)

University of Cincinnati (Cincinnati)

University of Dayton (Dayton)

University of Toledo (Toledo)

Wright State University (Dayton)

Oklahoma

Oklahoma State University (Stillwater)

University of Oklahoma (Norman)

\section{Oregon}

Oregon Graduate Institute of Science and Technology (Portland)

Oregon State University (Corvallis)

Portland State University (Portland) 
Pennsylvania

Carnegie Mellon University (Pittsburgh) Drexel University (Philadelphia) Lehigh University (Bethlehem) Pennsylvania State University (Landenberg) University of Pennsylvania (Philadelphia) University of Pittsburgh (Pittsburgh)

Villanova University (Villanova)

Rhode Island

Brown University (Providence)

\section{South Carolina}

Clemson University (Clemson)

Furman University (Greenville)

University of South Carolina (Columbia)

\section{South Dakota}

South Dakota State University (Brookings)

\section{Tennessee}

East Tennessee State University (Johnson City) Fisk University (Nashville)

Maryville College (Maryville)

Tennessee State University (Nashville)

Tennessee Technological University (Cookeville)

University of Memphis (Memphis)

University of Tennessee (Knoxville)

Vanderbilt University (Nashville)

\section{Texas}

Rice University (Houston)

Southwest Research Institute (San Antonio)

Texas A\&M University (College Station)

Texas Tech (Lubbock)

University of Houston (Houston)

University of North Texas (Denton)

University of Texas (Arlington)

University of Texas (Austin)

University of Texas (EI Paso)

University of Texas-Pan American (Edinburg)

\section{Utah}

University of Utah (Salt Lake City)

\section{Virginia}

Institute for Defense Analyses (Alexandria)

Norfolk State University (Norfolk)

University of Virginia (Charlottesville)

Virginia Polytechnic Institute and State University (Blacksburg)

\section{Washington}

Gonzaga University (Spokane)

University of Washington (Seattle)

Washington State University (Pullman)

Washington, D.C.

Georgetown University Medical Center Howard University

The George Washington University

\section{West Virginia}

West Virginia University (Morgantown)

\section{Wisconsin}

Marquette University (Milwaukee)

University of Wisconsin (Madison) 
HTML PROPOSAL LIST 

HTML Proposal List, FY 2005

\begin{tabular}{|c|c|c|c|c|c|}
\hline $\begin{array}{l}\text { Proposal } \\
\text { No. }\end{array}$ & Institution & $\begin{array}{l}\text { Lead } \\
\text { center }\end{array}$ & Proposal title & Spokesperson & Staff contact \\
\hline $2005-001$ & Unifrax Corporation (01) & TTPUC & $\begin{array}{l}\text { Thermal Conductivity Measurements of Fire } \\
\text { Protection Insulation Materials Using the Hot } \\
\text { Disk Thermal Constants Analyzer }\end{array}$ & Joseph A. Fernanado & Hsin Wang \\
\hline $2005-002$ & $\begin{array}{l}\text { Arizona State University } \\
(02)\end{array}$ & RSUC & $\begin{array}{l}\text { Residual Stress Measurements in Nanoscale } \\
\text { Multilayered Metal-Ceramic Films }\end{array}$ & Nik Chawla & Cam Hubbard \\
\hline $2005-003$ & Rice University (08) & MCAUC & $\begin{array}{l}\text { Fracture Toughness of Miniature Test } \\
\text { Specimens of Single-Walled Carbon Nanotube } \\
\text { Reinforced Silicon Nitride Composites }\end{array}$ & Enrique V. Barrera & $\begin{array}{l}\text { Edgar Lara- } \\
\text { Curzio }\end{array}$ \\
\hline $2005-004$ & Drexel University (09) & MAUC & $\begin{array}{l}\text { TEM Study of Nanostructured Self-Assembled } \\
\text { LaCrO }_{3} \text {-Based Thin Films for Catalysis in } \\
\text { Perovskite Related Membrane Reactors }\end{array}$ & Nina Orlovskaya & Larry Allard \\
\hline $2005-005$ & $\begin{array}{l}\text { University of Pennsylvania } \\
(02)\end{array}$ & DUC & $\begin{array}{l}\text { Thermal Expansion of Perovskite Based } \\
\text { Microwave Materials }\end{array}$ & Peter K. Davies & $\begin{array}{l}\text { Claudia Rawn } \\
\text { Andrew Payzant }\end{array}$ \\
\hline $2005-006$ & $\begin{array}{l}\text { Technology for Energy } \\
\text { Corporation }(02)\end{array}$ & RSUC & NIST Tracibility for Strain-Free Standard & V. Carol Bailey & $\begin{array}{l}\text { Tom Watkins } \\
\text { Cam Hubbard }\end{array}$ \\
\hline $2005-007$ & $\begin{array}{l}\text { Tennessee Technological } \\
\text { University (11) }\end{array}$ & DUC & $\begin{array}{l}\text { Chemical and Microstructural Characteristics of } \\
\text { the Alkali-Activated Reaction Between Blast } \\
\text { Furnace Slag and Calcium Hydroxide for } \\
\text { Reinforced Concrete. }\end{array}$ & Joseph J. Biernacki & $\begin{array}{l}\text { Cam Hubbard } \\
\text { Andrew Payzant }\end{array}$ \\
\hline $2005-008$ & $\begin{array}{l}\text { Southern Illinois University } \\
\text { (07) }\end{array}$ & TTPUC & $\begin{array}{l}\text { Nanoscale Tailored Materials for Thermal } \\
\text { Interfaces Used in Microelectronics }\end{array}$ & Punit Kohli & Ralph Dinwiddie \\
\hline $2005-009$ & University of Michigan (13) & FWMUC & Machining of Nano-Composite Materials & Albert J. Shih & $\begin{array}{l}\text { Peter Blau } \\
\text { Andrew Payzant } \\
\text { Larry Allard }\end{array}$ \\
\hline $2005-010$ & CTI, Inc. (06) & DUC & $\begin{array}{l}\text { Examination of the Crystal Structures in } \\
\text { Lutetium Aluminum Oxides (Luap and Luag) }\end{array}$ & Charles L. Melcher & $\begin{array}{l}\text { Larry Allard } \\
\text { Andrew Payzant }\end{array}$ \\
\hline $2005-011$ & University of Virginia (04) & MAUC & $\begin{array}{l}\text { ACEM Investigation of Small Metal Particles } \\
\text { and Metal Oxide Supported Composite } \\
\text { Nanocatalysts Produced by Pulsed Laser } \\
\text { Deposition }\end{array}$ & Vladimir P. Oleshko & Larry Allard \\
\hline $2005-012$ & Delphi Corporation (02) & TTPUC & $\begin{array}{l}\text { Fiber Optics for Temperature Sensing and Their } \\
\text { Effects on IR Detection }\end{array}$ & Kwangjin M. Lee & Ralph Dinwiddie \\
\hline
\end{tabular}


HTML Proposal List, FY 2005 (continued)

\begin{tabular}{|c|c|c|c|c|c|}
\hline $\begin{array}{l}\text { Proposal } \\
\text { No. }\end{array}$ & Institution & $\begin{array}{l}\text { Lead } \\
\text { center }\end{array}$ & Proposal title & Spokesperson & Staff contact \\
\hline $2005-013$ & $\begin{array}{l}\text { General Motors Powertrain } \\
(01)\end{array}$ & TTPUC & $\begin{array}{l}\text { Thermal Resistance Measurements Between IC } \\
\text { Engine Components }\end{array}$ & Scott J. Sochor & $\begin{array}{l}\text { Hsin Wang } \\
\text { Ralph Dinwiddie } \\
\text { Edgar Lara- } \\
\text { Curzio }\end{array}$ \\
\hline $2005-014$ & Purdue University (05) & TTPUC & Enhanced Conductivity Oxide Fuels & Alvin Solomon & $\begin{array}{l}\text { Cam Hubbard } \\
\text { Ralph Dinwiddie }\end{array}$ \\
\hline $2005-016$ & Clemson University (33) & MAUC & $\begin{array}{l}\text { Interfacial Analysis of Ultrasonically } \\
\text { Consolidated Metals and Alloys }\end{array}$ & Henry J. Rack & Larry Allard \\
\hline $2005-017$ & $\begin{array}{l}\text { Millennium Materials, Inc. } \\
\text { (02) }\end{array}$ & MAUC & SEM Operator Training & Sally Almond & Larry Allard \\
\hline $2005-018$ & $\begin{array}{l}\text { Hy-Tech Research } \\
\text { Corporation (04) }\end{array}$ & FWMUC & $\begin{array}{l}\text { Plasma Smoothing of Co-Cr-Mo Biomechanical } \\
\text { Implant Components }\end{array}$ & $\begin{array}{l}\text { C. Christopher } \\
\text { Klepper }\end{array}$ & $\begin{array}{l}\text { Peter Blau } \\
\text { Edgar Lara- } \\
\text { Curzio } \\
\text { Larry Allard } \\
\text { Larry Walker } \\
\text { Jun Qu } \\
\text { Laura Riester }\end{array}$ \\
\hline $2005-019$ & $\begin{array}{l}\text { University of Tennessee } \\
\text { (122) }\end{array}$ & MAUC & $\begin{array}{l}\text { As-Cast Bulk Metallic Glasses Containing } \\
\text { Nanocrystalline Particles }\end{array}$ & Cang Fan & $\begin{array}{l}\text { Hahn Choo } \\
\text { Larry Allard }\end{array}$ \\
\hline $2005-020$ & $\begin{array}{l}\text { State University of New } \\
\text { York at Stony Brook (03) }\end{array}$ & RSUC & $\begin{array}{l}\text { Thickness, Surface Roughness, and Interfacial } \\
\text { Roughness Studies of Silicon Carbide Coatings } \\
\text { By X-Ray Reflectivity }\end{array}$ & Henry J. White & Cam Hubbard \\
\hline $2005-021$ & $\begin{array}{l}\text { Johns Hopkins University } \\
\text { (04) }\end{array}$ & MCAUC & Thermal Properties of Ta-Based Alloys & Todd Hufnagel & $\begin{array}{l}\text { Edgar Lara- } \\
\text { Curzio }\end{array}$ \\
\hline $2005-023$ & Caterpillar, Inc. (20) & RSUC & $\begin{array}{l}\text { Weld Residual Stress Measurement Using X- } \\
\text { Ray Diffraction }\end{array}$ & Zhishang Yang & $\begin{array}{l}\text { Andrew Payzant } \\
\text { Cam Hubbard }\end{array}$ \\
\hline $2005-024$ & $\begin{array}{l}\text { Industrial Ceramic } \\
\text { Solutions, LLC (01) }\end{array}$ & MCAUC & $\begin{array}{l}\text { Temperature Profile of Microwave-Cleaned } \\
\text { Diesel Particulate Filter }\end{array}$ & Richard D. Nixdorf & Ralph Dinwiddie \\
\hline $2005-025$ & $\begin{array}{l}\text { Louisiana State University } \\
\text { (09) }\end{array}$ & FWMUC & $\begin{array}{l}\text { Evaluation of Sensory Signals and Work Piece } \\
\text { Quality as Wheel Condition Changes. }\end{array}$ & T. Warren Liao & Peter Blau \\
\hline $2005-026$ & UOP, LLC (01) & MAUC & Metal Atom Arrangement of Catalyst Supports & Steven A. Bradley & Larry Allard \\
\hline
\end{tabular}


HTML Proposal List, FY 2005 (continued)

\begin{tabular}{|c|c|c|c|c|c|}
\hline $\begin{array}{l}\text { Proposal } \\
\text { No. }\end{array}$ & Institution & $\begin{array}{l}\text { Lead } \\
\text { center }\end{array}$ & Proposal title & Spokesperson & Staff contact \\
\hline $2005-028$ & $\begin{array}{l}\text { Gamma Engineering } \\
\text { Corporation (02) }\end{array}$ & MCAUC & $\begin{array}{l}\text { Characterization of Mechanical Hoop Strength } \\
\text { of } \mathrm{SiC} / \mathrm{SiC} \text { Ceramic Composites and } \\
\text { Continuation of the Characterization of } \\
\text { Specimens Exposed to Water at Various } \\
\text { Environmental Conditions }\end{array}$ & Herbert Feinroth & $\begin{array}{l}\text { Edgar Lara- } \\
\text { Curzio } \\
\text { Larry Allard } \\
\text { Peter Blau }\end{array}$ \\
\hline $2005-029$ & Ford Motor Company (18) & TTPUC & $\begin{array}{l}\text { IR Inspection of Roof Ditch Laser Welds on a } \\
\text { Body-in-White Vehicle }\end{array}$ & William A. Charron & Hsin Wang \\
\hline $2005-030$ & $\begin{array}{l}\text { University of Missouri, } \\
\text { Rolla (04) }\end{array}$ & TTPUC & $\begin{array}{l}\text { Determining the Thermal Diffusivity of UHTCs } \\
\text { and Developing a Xenon Flash Diffusivity } \\
\text { Device }\end{array}$ & $\begin{array}{l}\text { William G. } \\
\text { Fahrenholtz }\end{array}$ & Ralph Dinwiddie \\
\hline $2005-031$ & $\begin{array}{l}\text { ORNL (27), Metals \& } \\
\text { Ceramics Division }\end{array}$ & RSUC & $\begin{array}{l}\text { Self-Organizing Fractal of Plastically Deformed } \\
\mathrm{Cu}\end{array}$ & Judy Pang & Cam Hubbard \\
\hline $2005-032$ & Ford Motor Company (19) & TTPUC & $\begin{array}{l}\text { "Effect of Processing Conditions on the Internal } \\
\text { Die Cavity Temperatures during Aluminum Die } \\
\text { Casting" }\end{array}$ & Jacob W. Zindel & Ralph Dinwiddie \\
\hline $2005-033$ & $\begin{array}{l}\text { University of Tennessee } \\
\text { (123) }\end{array}$ & MAUC & $\begin{array}{l}\text { Investigation of the Interaction Between Shear } \\
\text { Bands and Dislocations in Ductile Particle- } \\
\text { Containing Bulk Metallic Glass Composites }\end{array}$ & Cang Fan & $\begin{array}{l}\text { Hahn Choo } \\
\text { Larry Allard }\end{array}$ \\
\hline $2005-034$ & Purdue University (06) & TTPUC & $\begin{array}{l}\text { Thermal Conductivity Measurements of Plasma } \\
\text { Sprayed Coatings Made From } 8 \text { Wt. } \mathrm{Y}_{2} \mathrm{O}_{3}-\mathrm{ZrO}_{2} \\
\text { Hollow Sphere Powders }\end{array}$ & Rodney Trice & Hsin Wang \\
\hline $2005-035$ & Caterpillar, Inc. (21) & RSUC & $\begin{array}{l}\text { Sensitivity of Fracture Toughness To Quench } \\
\text { Rate in Sae4330 Modified Steel: Retained } \\
\text { Austenite and Residual Stress }\end{array}$ & Don H. Sherman & $\begin{array}{l}\text { Thomas Watkins } \\
\text { Cam Hubbard }\end{array}$ \\
\hline $2005-036$ & $\begin{array}{l}\text { California Institute of } \\
\text { Technology (01) }\end{array}$ & MAUC & $\begin{array}{l}\text { Scanning Auger Microscopy of Alkylated } \\
\text { Crystalline Silicon (111) Surfaces }\end{array}$ & Nathan Lewis & $\begin{array}{l}\text { Harry Meyer } \\
\text { Larry Allard }\end{array}$ \\
\hline $\begin{array}{l}2005- \\
037\end{array}$ & Met Con (01) & MAUC & Corrosion of Small 52100 Bearing Rings & Harry W. Walton & Harry Meyer \\
\hline $2005-038$ & $\begin{array}{l}\text { Colorado School of Mines } \\
\text { (02) }\end{array}$ & TTPUC & $\begin{array}{l}\text { Construction of CCT Diagrams for Use in } \\
\text { Production of Ultrafine Ferrite }\end{array}$ & David K. Matlock & Ralph Dinwiddie \\
\hline $2005-039$ & $\begin{array}{l}\text { University of Tennessee } \\
\text { (124) }\end{array}$ & MAUC & $\begin{array}{l}\text { Morphological Studies of Organic Electro- } \\
\text { Phosphorescent Composites }\end{array}$ & $\mathrm{Bin} \mathrm{Hu}$ & $\begin{array}{l}\text { Jane Howe } \\
\text { Larry Allard }\end{array}$ \\
\hline $2005-040$ & $\begin{array}{l}\text { Pacific Northwest National } \\
\text { Laboratory (01) }\end{array}$ & FWMUC & $\begin{array}{l}\text { Hydrogen Surface Effects on H-Ice Injector } \\
\text { Materials }\end{array}$ & James David Holbery & $\begin{array}{l}\text { Peter Blau } \\
\text { Laura Riester }\end{array}$ \\
\hline
\end{tabular}


HTML Proposal List, FY 2005 (continued)

\begin{tabular}{|c|c|c|c|c|c|}
\hline $\begin{array}{l}\text { Proposal } \\
\text { No. }\end{array}$ & Institution & $\begin{array}{l}\text { Lead } \\
\text { center }\end{array}$ & Proposal title & Spokesperson & Staff contact \\
\hline $2005-041$ & University of Maine (02) & MAUC & $\begin{array}{l}\text { Characterization of Silver Metal Clusters in } \\
\text { Mesoporous Material }\end{array}$ & Susan G. Mackay & Larry Allard \\
\hline $2005-042$ & $\begin{array}{l}\text { Saint-Gobain Northboro } \\
\text { Research \& Development } \\
\text { Center (17) }\end{array}$ & TTPUC & $\begin{array}{l}\text { Influence of Phase Content and Porosity on the } \\
\text { Thermal Conductivity of Bulk Sintered Zirconias } \\
\text { Stabilized with Various Dopants }\end{array}$ & Gaetan Bonhomme & Ralph Dinwiddie \\
\hline $2005-043$ & $\begin{array}{l}\text { Metal Casting Technology, } \\
\text { Inc. (02) }\end{array}$ & TTPUC & $\begin{array}{l}\text { Quantitative Analysis of Heat Transfer in the } \\
\text { Lost Foam Aluminum Process }\end{array}$ & Qi Zhao & Ralph Dinwiddie \\
\hline $2005-044$ & Better Than New (04) & FWMUC & $\begin{array}{l}\text { Frictional Behavior of Treated and Untreated } \\
\text { Amorphous Metals }\end{array}$ & Thomas E. Steffner & Peter Blau \\
\hline $2005-046$ & $\begin{array}{l}\text { ORNL (28), Spallation } \\
\text { Neutron Source }\end{array}$ & TTPUC & $\begin{array}{l}\text { Thermodynamic and Microscopy Study of Zr- } \\
\text { Based Bulk Metallic Glass }\end{array}$ & Xun-Li Wang & $\begin{array}{l}\text { Ralph Dinwiddie } \\
\text { Wally Porter }\end{array}$ \\
\hline $2005-047$ & $\begin{array}{l}\text { Massachusetts Institute of } \\
\text { Technology (04) }\end{array}$ & TTPUC & $\begin{array}{l}\text { Determination of the Temperature Dependent } \\
\text { Thermal Properties of Nanofluids }\end{array}$ & Jacopo Buongiorno & Hsin Wang \\
\hline $2005-048$ & TPL, Incorporated (03) & RSUC & $\begin{array}{l}\text { Residual Stress Analysis of Explosively Clad } \\
\text { Steel Barrels }\end{array}$ & Douglas J. Taylor & $\begin{array}{l}\text { Tom Watkins } \\
\text { Cam Hubbard }\end{array}$ \\
\hline $2005-049$ & $\begin{array}{l}\text { Kansas State University } \\
(08)\end{array}$ & MAUC & $\begin{array}{l}\text { The Effect of Composition On the Structure of } \\
\text { AIN-SiC Alloy Crystals }\end{array}$ & James H. Edgar & $\begin{array}{l}\text { Larry Walker } \\
\text { Andrew Payzant }\end{array}$ \\
\hline $2005-050$ & $\begin{array}{l}\text { Federal Mogul Corporation } \\
(02)\end{array}$ & MAUC & $\begin{array}{l}\text { Spark Plug Electrode Alloy Characterization and } \\
\text { Development for Gasoline Engines }\end{array}$ & Iryna M. Levina & $\begin{array}{l}\text { Larry Allard } \\
\text { Mike Brady }\end{array}$ \\
\hline $2005-051$ & University of Florida (11) & DUC & $\begin{array}{l}\text { In Situ Investigation of the Reaction Kinetics } \\
\text { and Pathways of } \mathrm{Cu}(\mathrm{In}, \mathrm{Ga}) \mathrm{Se}_{2} \text { Formation } \\
\text { from Various Precursor Structures }\end{array}$ & Timothy J. Anderson & $\begin{array}{l}\text { Andrew Payzant } \\
\text { Doug Blom }\end{array}$ \\
\hline $2005-052$ & $\begin{array}{l}\text { Arizona State University } \\
\text { (03) }\end{array}$ & RSUC & $\begin{array}{l}\text { In Situ Phase Stress Partitioning Measurement } \\
\text { in Al Matrix Composites }\end{array}$ & Nikhilesh Chawla & $\begin{array}{l}\text { Cam Hubbard } \\
\text { Fei Tang }\end{array}$ \\
\hline $2005-053$ & Foseco-Morval (01) & TTPUC & Lost Foam Casting in Alternate Environments & Dennis Nolan & Ralph Dinwiddie \\
\hline $2005-054$ & $\begin{array}{l}\text { Walford Technologies, } \\
\text { Inc., (02) and } \\
\text { D8, Inc. (01) }\end{array}$ & TTPUC & $\begin{array}{l}\text { Understanding and Quantifying Expanded } \\
\text { Polystyrene Bead Bond and Internal Bead } \\
\text { Structures }\end{array}$ & Graham V. Walford & Ralph Dinwiddie \\
\hline $2005-055$ & $\begin{array}{l}\text { Arizona State University } \\
\text { (04) }\end{array}$ & RSUC & $\begin{array}{l}\text { Residual Stress Measurements in Anodically } \\
\text { Oxidized Titanium }\end{array}$ & Nikhilesh Chawla & Cam Hubbard \\
\hline $2005-056$ & $\begin{array}{l}\text { University of Tennessee } \\
\text { (125) }\end{array}$ & RSUC & $\begin{array}{l}\text { Mapping of Hydrogen Contained Through } \\
\text { Zircaloy-4 }\end{array}$ & Hahn Choo & Cam Hubbard \\
\hline
\end{tabular}


HTML Proposal List, FY 2005 (continued)

\begin{tabular}{|c|c|c|c|c|c|}
\hline $\begin{array}{l}\text { Proposal } \\
\text { No. }\end{array}$ & Institution & $\begin{array}{l}\text { Lead } \\
\text { center }\end{array}$ & Proposal title & Spokesperson & Staff contact \\
\hline $2005-057$ & $\begin{array}{l}\text { Advanced Computational } \\
\text { \& Engineering Services, } \\
\text { LLC (01) }\end{array}$ & RSUC & $\begin{array}{l}\text { Residual Stress Analysis of Laser Shock } \\
\text { Processed Components }\end{array}$ & $\begin{array}{l}\text { Kyle C. } \\
\text { Koppenhoefer }\end{array}$ & Cam Hubbard \\
\hline $2005-058$ & Purdue University (07) & TTPUC & $\begin{array}{l}\text { Vanadium Oxide Contaminant Threshold for } \\
\text { Thermal Barrier Coatings }\end{array}$ & Rodney W. Trice & $\begin{array}{l}\text { Hsin Wang } \\
\text { Jane Howe } \\
\text { Scott Speakman }\end{array}$ \\
\hline 2005-059 & lowa State University (07) & RSUC & $\begin{array}{l}\text { In Situ Phase Stress Partitioning Measurement } \\
\text { in Al/Al-Cu-Fe Composites }\end{array}$ & Iver E. Anderson & $\begin{array}{l}\text { Fei Tang } \\
\text { Cam Hubbard }\end{array}$ \\
\hline $2005-060$ & University of Maine (03) & DUC & $\begin{array}{l}\text { Measurement of Thermal Expansion Coefficient } \\
\text { of LGT }\end{array}$ & $\begin{array}{l}\text { Mauricio Pereira Da } \\
\text { Cunha }\end{array}$ & $\begin{array}{l}\text { Andrew Payzant } \\
\text { Wally Porter }\end{array}$ \\
\hline $2005-061$ & $\begin{array}{l}\text { Cummins Engine } \\
\text { Company, Inc. (32) }\end{array}$ & RSUC & Catalyzed Soot Filter Characterization & Roger Dale England & Tom Watkins \\
\hline $2005-062$ & $\begin{array}{l}\text { Pennsylvania State } \\
\text { University (32) }\end{array}$ & FWMUC & $\begin{array}{l}\text { Development of Ti-Alloy Lubricants-the Use of } \\
\text { Nanoparticles }\end{array}$ & Seong H. Kim & Jun Qu \\
\hline $2005-063$ & $\begin{array}{l}\text { Oshkosh Truck } \\
\text { Corporation (01) }\end{array}$ & MAUC & Magnesium for Heavy Truck Applications & Robert M. Hathaway & Larry Allard \\
\hline $2005-064$ & $\begin{array}{l}\text { Porvair Fuel Cell } \\
\text { Technology (03) }\end{array}$ & MCAUC & $\begin{array}{l}\text { Investigation Into Improving Strength and } \\
\text { Pressure Drop of Metal Foams for Use as } \\
\text { Converters in Diesel Particulate Applications }\end{array}$ & $\begin{array}{l}\text { Stacia M. Wagner- } \\
\text { Sparks }\end{array}$ & $\begin{array}{l}\text { Edgar Lara- } \\
\text { Curzio }\end{array}$ \\
\hline $2005-065$ & $\begin{array}{l}\text { College of William and } \\
\text { Mary (01) CNMS }\end{array}$ & MAUC & $\begin{array}{l}\text { Formation Mechanism and Properties of Carbon } \\
\text { Nanosheets }\end{array}$ & Brian C. Holloway & Larry Allard \\
\hline $2005-066$ & $\begin{array}{l}\text { State University of New } \\
\text { York at Stony Brook (04) }\end{array}$ & TTPUC & $\begin{array}{l}\text { Investigation of Thermal Conductivity for } \\
\text { Plasma Spray YSZ Coatings }\end{array}$ & Sanjay Sampath & Hsin Wang \\
\hline $2005-067$ & Tuskegee University (07) & MAUC & Microstructual Effects of Rail Defects & Heshmat A. Aglan & Larry Allard \\
\hline $2005-068$ & ZS Genetics, Inc. (01) & MAUC & $\begin{array}{l}\text { Feasibility Test of Z-Labeled TEM Genetic } \\
\text { Sequencing }\end{array}$ & William R. Glover & Larry Allard \\
\hline $2005-069$ & $\begin{array}{l}\text { University of Tennessee } \\
(126)\end{array}$ & RSUC & $\begin{array}{l}\text { Characterizing Stresses Near a Crack Through } \\
\text { the Retardation Period After Fatigue Overload }\end{array}$ & Peter K. Liaw & Cam Hubbard \\
\hline $2005-070$ & Corning Inc. (09) & MCAUC & $\begin{array}{l}\text { Mechanical Response of Microcracked } \\
\text { Ceramics }\end{array}$ & James E. Webb & $\begin{array}{l}\text { Edgar Lara- } \\
\text { Curzio }\end{array}$ \\
\hline $2005-071$ & Caterpillar, Inc. (22) & MCAUC & $\begin{array}{l}\text { Creep Properties and Microstructure Stability of } \\
\text { Hip'ed and Non-Hip'ed Cast Garma TiAl }\end{array}$ & Nan Yang & $\begin{array}{l}\text { Edgar Lara- } \\
\text { Curzio }\end{array}$ \\
\hline $2005-072$ & $\begin{array}{l}\text { Georgia Institute of } \\
\text { Technology (53) }\end{array}$ & MCAUC & $\begin{array}{l}\text { A Design Methodology for Mica-Based } \\
\text { Compressive Seals }\end{array}$ & Jeffrey Streator & $\begin{array}{l}\text { Edgar Lara- } \\
\text { Curzio }\end{array}$ \\
\hline
\end{tabular}


HTML Proposal List, FY 2005 (continued)

\begin{tabular}{|c|c|c|c|c|c|}
\hline $\begin{array}{l}\text { Proposal } \\
\text { No. }\end{array}$ & Institution & $\begin{array}{l}\text { Lead } \\
\text { center }\end{array}$ & Proposal title & Spokesperson & Staff contact \\
\hline $2005-073$ & Pratt \& Whitney (03) & MCAUC & $\begin{array}{l}\text { Interfacial Shear Strength in Advanced CMC } \\
\text { With and Without Exposure }\end{array}$ & Greg C. Ojard & $\begin{array}{l}\text { Edgar Lara- } \\
\text { Curzio }\end{array}$ \\
\hline $2005-074$ & $\begin{array}{l}\text { University of Rochester } \\
\text { (02) }\end{array}$ & MAUC & $\begin{array}{l}\text { Fate of Engineered Nanoparticles in the } \\
\text { Mammalian Organism }\end{array}$ & Gunter Oberdorster & Doug Blom \\
\hline $2005-075$ & Ford Motor Company (20) & TTPUC & $\begin{array}{l}\text { Non-Destructive Evaluation of Aluminum Spot } \\
\text { Friction Welds Using Thermography }\end{array}$ & Tsung-Yu Pan & Hsin Wang \\
\hline $2005-077$ & $\begin{array}{l}\text { University of Tennessee } \\
\text { (127) }\end{array}$ & MAUC & $\begin{array}{l}\text { Study of Atomic Arrangement in As-Cast and } \\
\text { Heat Treatment Bulk Metallic Glasses }\end{array}$ & Chain T. Liu & Larry Allard \\
\hline $2005-080$ & Drexel University (10) & DUC & $\begin{array}{l}\text { Detection of Deformation Mechanisms of } \\
\text { Ferroelastic } \mathrm{LaCO}_{3} \text { Based Perovskites By TEM } \\
\text { and In Situ XRD }\end{array}$ & Nina Orlovskaya & $\begin{array}{l}\text { Tom Watkins } \\
\text { Larry Allard }\end{array}$ \\
\hline $2005-081$ & $\begin{array}{l}\text { Third Wave Systems, MN } \\
\text { (02) }\end{array}$ & RSUC & Stress Characterization and Model Validation & Troy D. Marusich & Cam Hubbard \\
\hline $2005-082$ & $\begin{array}{l}\text { Georgia Institute of } \\
\text { Technology (54) }\end{array}$ & DUC & $\begin{array}{l}\text { High-Temperature Diffraction Studies of Low } \\
\text { and Negative Thermal Expansion Phosphates }\end{array}$ & Angus P. Wilkinson & Andrew Payzant \\
\hline $2005-083$ & $\begin{array}{l}\text { University of Tennessee } \\
\text { (128) }\end{array}$ & RSUC & $\begin{array}{l}\text { Deformation Behavior of Materials under } \\
\text { Tension and Torsion }\end{array}$ & Dayakar Penumadu & Cam Hubbard \\
\hline $2005-084$ & $\begin{array}{l}\text { North Carolina State } \\
\text { University (40) }\end{array}$ & FWMUC & $\begin{array}{l}\text { Production of Nano-Grained Silicon Nitride } \\
\text { Powder by Single Point Turning }\end{array}$ & Michael J. Rigsbee & Peter Blau \\
\hline $2005-085$ & Clemson University (34) & TTPUC & $\begin{array}{l}\text { Thermal Properties of Polymeric Carbon } \\
\text { Nanocomposite Films }\end{array}$ & Ya-Ping Sun & Hsin Wang \\
\hline $2005-086$ & University of Arkansas (06) & DUC & $\begin{array}{l}\text { Structural Investigations of Alumina Coatings by } \\
\text { High-Temperature X-Ray and Electron } \\
\text { Diffraction Techniques }\end{array}$ & Deepak Govind Bhat & $\begin{array}{l}\text { Andrew Payzant } \\
\text { Tom Watkins } \\
\text { Larry Allard }\end{array}$ \\
\hline $2005-087$ & $\begin{array}{l}\text { University of North } \\
\text { Carolina-Charlotte (02) }\end{array}$ & FWMUC & $\begin{array}{l}\text { Characteristics of Ductile Regime Grinding of } \\
\text { Silicon Nitride }\end{array}$ & $\begin{array}{l}\text { Harischandra P. } \\
\text { Cherukuri }\end{array}$ & Peter Blau \\
\hline $2005-089$ & $\begin{array}{l}\text { Georgia Institute of } \\
\text { Technology (55) }\end{array}$ & RSUC & $\begin{array}{l}\text { Mechanisms and Modeling of White Layer } \\
\text { Formation in Orthogonal Machining of Steels }\end{array}$ & Shreyes N. Melkote & $\begin{array}{l}\text { Tom Watkins } \\
\text { Laura Riester }\end{array}$ \\
\hline $2005-091$ & $\begin{array}{l}\text { Colorado School of Mines } \\
\text { (03) }\end{array}$ & DUC & $\begin{array}{l}\text { Palladium/Copper Alloy Composite Membranes } \\
\text { for High-Temperature Hydrogen Separation and } \\
\text { Cost-Effective Method for Producing Self- } \\
\text { Supported, Palladium Alloy Membranes for Use } \\
\text { in the Efficient Production of Coal-Derived } \\
\text { Hydrogen }\end{array}$ & J. Douglas Way & Andrew Payzant \\
\hline
\end{tabular}


HTML Proposal List, FY 2005 (continued)

\begin{tabular}{|c|c|c|c|c|c|}
\hline $\begin{array}{l}\text { Proposal } \\
\text { No. }\end{array}$ & Institution & $\begin{array}{l}\text { Lead } \\
\text { center }\end{array}$ & Proposal title & Spokesperson & Staff contact \\
\hline $2005-092$ & $\begin{array}{l}\text { Acceledyne Corporation } \\
(01)\end{array}$ & MAUC & $\begin{array}{l}\text { TEM Examination of Alloys With Accelerated } \\
\text { Thermal Processing }\end{array}$ & Donna M. Walker & Larry Allard \\
\hline $2005-093$ & $\begin{array}{l}\text { University of Tennessee } \\
\text { (123) }\end{array}$ & MAUC & $\begin{array}{l}\text { Studies on the Effects of Applied Stresses on } \\
\text { the Oxidation Processes of Haynes } 75 \text { and } \\
\text { Haynes } 230 \text { Superalloys }\end{array}$ & Peter K. Liaw & $\begin{array}{l}\text { Edgar Lara- } \\
\text { Curzio }\end{array}$ \\
\hline $2005-094$ & University of Michigan (15) & MCAUC & $\begin{array}{l}\text { Effect of Sr Addition on the Solid-Solution } \\
\text { Strengthening of } \mathrm{Mg} \text {-Al-Ca Alloys }\end{array}$ & Akane Suzuki & Laura Riester \\
\hline 2005-095 & $\begin{array}{l}\text { Advanced Ceramics } \\
\text { Research, Inc. (05) }\end{array}$ & MAUC & $\begin{array}{l}\text { A Novel Micro-Channel Heat Exchanger for } \\
\text { High Heat Flux Electronics }\end{array}$ & $\begin{array}{l}\text { Ranji K. } \\
\text { Vaidyanathan }\end{array}$ & $\begin{array}{l}\text { Edgar Lara- } \\
\text { Curzio }\end{array}$ \\
\hline $2005-096$ & $\begin{array}{l}\text { University of Central } \\
\text { Florida (05) }\end{array}$ & TTPUC & $\begin{array}{l}\text { Thermal Conductivity of Polymer-Derived SiCN } \\
\text { and SiBCN }\end{array}$ & An Linan & Hsin Wang \\
\hline $2005-097$ & $\begin{array}{l}\text { Dow Chemical Company } \\
\text { (Midland) (13) }\end{array}$ & MAUC & $\begin{array}{l}\text { High-Resolution TEM Investigation of a } 2 \% \mathrm{Pd}- \\
\text { Silica Catalyst for Hydrogenation of } 1,2 \\
\text { Dichloropropane PDC }\end{array}$ & John H. Blackson & Larry Allard \\
\hline $2005-098$ & $\begin{array}{l}\text { University of Tennessee } \\
\text { (124) }\end{array}$ & RSUC & $\begin{array}{l}\text { Neutron Diffraction Measurement of Residual } \\
\text { Stresses in Carburized Gear Teeth }\end{array}$ & Robert A. Lemaster & Cam Hubbard \\
\hline 2005-099 & $\begin{array}{l}\text { Miami University of Ohio } \\
(01)\end{array}$ & TTPUC & Thermal Conductivity of Paper Coating & Lei Li Kerr & Ralph Dinwiddie \\
\hline $2005-100$ & $\begin{array}{l}\text { Famfive Productions, Inc. } \\
\text { (01) }\end{array}$ & TTPUC & Infrared Images as Archaeological Tools & Stephen Wilbur Dean & Ralph Dinwiddie \\
\hline $2005-101$ & $\begin{array}{l}\text { North Carolina State } \\
\text { University (41) }\end{array}$ & RSUC & $\begin{array}{l}\text { Novel Polymer Structures for Optical Sources } \\
\text { and Detectors for Intra-Chip Interconnects }\end{array}$ & M. Osama Aboelfotoh & Tom Watkins \\
\hline $2005-102$ & $\begin{array}{l}\text { Pennsylvania State } \\
\text { University (33) }\end{array}$ & MAUC & $\begin{array}{l}\text { Single Atom Imaging of Au Catalyst } \\
\text { Incorporation in Si Nanowires Synthesized Via } \\
\text { VLS Growth }\end{array}$ & Trevor E. Clark & Doug Blom \\
\hline $2005-103$ & $\begin{array}{l}\text { University of South } \\
\text { Carolina (07) }\end{array}$ & MAUC & $\begin{array}{l}\text { Microscopic Investigation of Nanoparticle Size } \\
\text { and Composition Distributions in } \mathrm{Pt}-\mathrm{Cu} / \mathrm{SiO}_{2} \\
\text { Bimetallic Catalysts }\end{array}$ & $\begin{array}{l}\text { Christopher T. } \\
\text { Williams }\end{array}$ & $\begin{array}{l}\text { Larry Allard } \\
\text { Jane Howe }\end{array}$ \\
\hline $2005-104$ & Corning Inc. (10) & RSUC & $\begin{array}{l}\text { Stress Characterization of Diesel Particulate } \\
\text { Filter Materials and Filters }\end{array}$ & James E. Webb & Cam Hubbard \\
\hline $2005-106$ & $\begin{array}{l}\text { Data Machine International } \\
\text { (01) }\end{array}$ & RSUC & $\begin{array}{l}\text { Use of the 4-Peak Method To Measure Low } \\
\text { Levels of Ra in Bearing Steel }\end{array}$ & $\begin{array}{l}\text { George G. } \\
\text { Gorbatenko }\end{array}$ & Camden Hubbard \\
\hline
\end{tabular}


HTML Proposal List, FY 2005 (continued)

\begin{tabular}{|c|c|c|c|c|c|}
\hline $\begin{array}{l}\text { Proposal } \\
\text { No. }\end{array}$ & Institution & $\begin{array}{l}\text { Lead } \\
\text { center }\end{array}$ & Proposal title & Spokesperson & Staff contact \\
\hline $2005-107$ & $\begin{array}{l}\text { Virginia Polytechnic } \\
\text { Institute and State } \\
\text { University (23) }\end{array}$ & DUC & $\begin{array}{l}\text { Fabrication and Characterization of } \\
\text { Nanocrystalline Metal Powders }\end{array}$ & Jeffrey P.Schultz & Andrew Payzant \\
\hline $2005-108$ & Corning Inc. (11) & MCAUC & $\begin{array}{l}\text { Thermomechanical Characterization of 3-YSZ } \\
\text { Thin Membranes for SOFC Applications }\end{array}$ & Sujanto Widjaja & $\begin{array}{l}\text { Edgar Lara- } \\
\text { Curzio }\end{array}$ \\
\hline 2005-109 & $\begin{array}{l}\text { Edison Materials } \\
\text { Technology Center (02) }\end{array}$ & MCAUC & $\begin{array}{l}\text { Measurement of Viscoelastic Properties of } \\
\text { Investment Casting Waxes }\end{array}$ & Nick Cannell & $\begin{array}{l}\text { Edgar Lara- } \\
\text { Curzio }\end{array}$ \\
\hline $2005-110$ & GS Engineering, Inc.(01) & MAUC & Magnesium Metal Matrix Composites & Adam R.Loukus & Larry Allard \\
\hline
\end{tabular}




\section{PUBLICATIONS AND PRESENTATIONS FY 2004}

Note: Boldface indicates HTML staff members.

\section{Journal Articles}

Akdogan, E. K., C. J. Rawn, W. D. Porter, E. A. Payzant, and A. Safari, "Size effects in $\mathrm{PbTiO}_{3}$ nanocrystals: Effect of particle size on spontaneous polarization and strains," J. Appl. Phys. 97, 084305 (2005).

Aytug, T., M. Paranthaman, K. J. Leonard, H. Y. Zhai, M. S. Bhuiyan, E. A. Payzant, A. Goyal, S. Sathyamurthy, D. B. Beach, P. M. Martin, D. K. Christen, X. Li, T. Kodenkandath, U. Schoop, and M. W. Rupich, "Assessment of chemical solution synthesis and properties of $\mathrm{Gd}_{2} \mathrm{Zr}_{2} \mathrm{O}_{7}$ thin films as buffer layers for second generation high-temperature superconductor wires," J. Mater. Res. 20, 2988-96 (2005).

Benson, M. L., T. A. Saleh, H. Choo, D. W. Brown, M. R. Daymond, X. L. Wang, A. D. Stoica, R. A. Buchanan, and D. L. Klarstrom, "Fatigue-induced phase formation and its deformation behavior in a cobalt-based superalloy," Powder Diffraction 20, 121-24 (2005).

Bhirud, V. A., M. J. Moses, D. A. Blom, L. F. Allard, T. Aoki, S. Mishina, C. K. Narula, and B. C. Gates, "Alumina-supported tri-rhenium clusters revealed by aberration-corrected electron microscopy," Microscopy and Microanalysis (2005) (first place award winner in Physical Sciences competition).

Brady, M. P., P. F. Tortorelli, K. L. More, E. A. Payzant, B. L. Armstrong, H. T. Lin, M. J. Lance, F. Huang, and M. L. Weaver, "Coating and near-surface modification design strategies for protective and functional surfaces," Materials and Corrosion 56, 746-55 (2005)

Chien, W-M., D. Chandra, J. Franklin, C. J. Rawn, and A. K. Helmy, "X-ray diffractometry studies and lattice parameter calculation on $\mathrm{KNO}_{3}-\mathrm{NH}_{4} \mathrm{NO}_{3}$ solid solutions," Powder Diff. 20, 101-104 (2005).

Chien, W-M., D. Chandra, A. K. Helmy, J. Franklin, and C. J. Rawn, "Experimental determination of $\mathrm{NH}_{4} \mathrm{NO}_{3}-\mathrm{KNO}_{3}$ binary phase diagram," J. Phase Equil. Diff. 26, 115-22 (2005).

Chen, Z., R. Trice, H. Wang, W. Porter, J. Howe, M. Besser, and D. Sordelet, "Co-doping of air plasma-sprayed yttria- and ceria-stabilized zirconia for thermal barrier applications," Journal of the American Ceramic Society 88 (6), 1584-90 (2005).

Choi, S. Y., M. Mamak, S. A. Speakman, N. Chopra, and G. A. Ozin, "Evolution of nanocrystallinity in periodic mesoporous anatase thin films," Small 1, 226-32 (2005).

Easton, D. S., J. H. Schneibel, and S. A. Speakman, "Factors affecting hydrogen release from lithium alanate ( $\left.\mathrm{LiAlH}_{4}\right)$," J. Alloys Comp. 398, 245-48 (2005).

Evans, R.D., J. Y. Howe, J. Bentley, G. L. Doll, and J. T. Glass, "Influence of deposition parameters on the composition and structure of reactively sputtered nanocomposite TaC/aC:H thin films," J. Mater. Res. 20 (9), 2583-96 (2005).

Fernando, K. A. S., Y. Lin, B. Zhou, M. Grah, R. Joseph, L. F. Allard, and Y. P. Sun, "Poly(ethylene-co-vinyl alcohol) functionalized single-walled carbon nanotubes and related nanocomposites," J. Nanoscience and Nanotechnology 5 (7), 1050-54 (2005). 
Gu, Z., J. H. Edgar, S. A. Speakman, D. Blom, J. Perrin, and J. Chaudhuri, "Thermal oxidation of polycrystalline and single crystalline aluminum nitride wafers," J. Electr. Mater. 34, 1271-79 (2005).

Haluska, M. S., S. A. Speakman, and S. T. Misture, "Powder diffraction data for the three-layer Aurivillius ceramics $\mathrm{Bi}_{2} \mathrm{Sr}_{2-x} \mathrm{~A}_{x} \mathrm{Nb}_{2} \mathrm{TiO}_{12}(\mathrm{~A}=\mathrm{Ca}, \mathrm{Ba}, \mathrm{x}=0,0.5,1)$," Powder Diff. 20, 47-50 (2005).

Haouaoui, M., K. T. Hartwig, and E. A. Payzant, "Effect of the strain path on annealing microstructure and texture development in pure copper processed by simple shear," Acta Mater. 53, 801-810 (2005).

Hill, D., Y. Lin, L. W. Qu, A. Kitaygorodskiy, J. W. Connell, L. F. Allard, and Y. P. Sun, "Functionalization of carbon nanotubes with derivatized polyimide," Macromolecules 38 (18), 7670-75 (2005).

Hossain, M., H. H. Abu-Safe, H. Naseem, W. D. Brown, and H. M. Meyer III, "Aluminum induced crystallization of sputtered hydrogenated amorphous silicon for economically viable thin film silicon solar cells," pp. 1088-91 in Conference Record of the Thirty-First IEEE Photovoltaic Specialists Conference 3-7 January 2005 (2005).

Hua, J., R. Shivpuri, X. Cheng, V. Bedekar, Y. Matsumoto, F. Hasimoto, and T. R. Watkins, "Effect of feed rate, workpiece hardness and cutting edge on subsurface residual stress in the hard turning of bearing steel using camfer+hone-cutting edge geometry," Mater. Sci. \& Eng. A 394 (1-2), 238-48 (2005).

Ice, G., C. R. Hubbard, B. C. Larson, J. D. Budai, and S. Spooner, "Kirkpatrick-Baez microfocusing optics for thermal neutrons," Nuclear Instruments and Methods A 539, 312-20 (2005).

Kim, W. K., S. Kim, E. A. Payzant, S. A. Speakman, S. Yoon, R. M. Kaczynski, R. D. Acher, T. J. Anderson, O. D. Crisalle, S. S. Li, and V. Craciun, "Reaction kinetics of alpha-CulnSe ${ }_{2}$ formation from an $\ln _{2} \mathrm{Se}_{3} / \mathrm{CuSe}$ bilayer precursor film," J. Phys. Chem. Solids 66, 1915-19 (2005).

Klepper, C. C., E. P. Carlson, R. C. Hazelton, E. J. Yadlowsky, M. A. Taher, B. Feng, and H. M. Meyer III, "H-alpha emission as a plasma vapor deposition control sensor for tribological, diamond-like carbon coatings," IEEE Transactions on Plasma Science 23 (2), 799-807 (2005).

Li, J. H., S. C. Moss, Y. Zhang, A. Mascarenhas, and J. Bai, "X-ray characterization of atomiclayer superlattices," J. Phys. D: Appl. Phys. 38 A147-53 (2005).

Li, J. H., D. W. Stokes, O. Caha, S. L. Ammu, J. Bai, K. E. Bassler, and S. C. Moss, "Morphological instability in InAs/GaSb superlattices due to interfacial bonds," Phys. Rev. Lett. 95, 096104 (2005).

Lin, Y., B. Zhou, R. B. Martin, K. B. Henbest, B. A. Harruff, J. E. Riggs, Z. X. Guo, L. F. Allard, and Y. P. Sun, "Visible luminescence of carbon nanotubes and dependence on functionalization," J. Phys. Chem. B 109 (31), 14779-82 (2005).

Lu, Z. G., J. H. Zhu, E. A. Payzant, and M. Paranthaman, "Electrical conductivity of manganese chromite spinel," J. Am. Ceram. Soc. 88, 1050-53 (2005).

Luo, J., V. K. Gupta, D. H. Yoon, and H. M. Meyer III, "Segregation-induced grain boundary premelting in nickel-doped tungsten," Applied Physics Letters 87, 231902 (2005). 
McMahon, M. D., R. Lopez, H. M. Meyer III, L. C. Feldman, and R. F. Haglund, "Rapid tarnishing of silver nanoparticles in ambient laboratory air," Appl. Phys. B, 00, 1-7, (2005).

Meziani, M. J., P. Pathak, F. Beacham, L. F. Allard, and Y. P. Sun, "Nanoparticle formation in rapid expansion of water-in-supercritical carbon dioxide microemulsion into liquid solution," J. Supercritical Fluids 34 (1), 91-97 (2005).

Miller, S. F., C. C. Kao, A. J. Shih, and J. Qu, "Investigation of wire electrical discharge machining of thin cross-sections and compliant mechanisms," International Journal of Machine Tools \& Manufacture 45 (15), 1641-1740 (2005).

Nagarajan, R. Z. Xu, J. H. Edgar, F. Baig, J. Chaudhuri, Z. Kek, E. A. Payzant, H. M. Meyer, J. Pomeroy, and M. Kuball, "Crystal growth of $\mathrm{B}_{12} \mathrm{As}_{2}$ on $\mathrm{SiC}$ substrate by CVD method," J. Cryst. Growth 273, 431-38 (2005).

Omiatek, D., C. A. Bessel, G. C. Papaefthymiou, A. J. Viescas, L. F. Allard, and D. A. Blom, "Characterization of metallic catalysts used in carbon nanofiber formation," Amer. Chem. Soc. Abst., U1051-U1051 578-INOR Part 1 (March 13, 2005).

Pan, Y., J. H. Zhu, M. Z. Hu, and E. A. Payzant, "Processing of YSZ thin films on dense and porous substrates," Surf. Coat. Technol. 200, 1242-47 (2005).

Price, M. J. Dong, X. Gu, S. A. Speakman, E. A. Payzant, and T. M. Nenoff, "Formation of YSZSDC solid solution in a nanocrystalline heterophase system and its effect on the electrical conductivity," J. Am. Ceram. Soc. 88, 1812-18 (2005).

Qazi, J. I., B. Marquardt, L. F. Allard, and H. J. Rack, "Phase transformations in Ti-35Nb-7Zr5Ta-(0.06-0.68)O alloys," Mat. Sci. \& Engr. C-Biomimetic and Supramolecular Systems 25 (3), 389-97 (2005).

Qu, J., J. J. Truhan, and P. J. Blau, "Application of the ASTM loop abrasion test to cylindrical specimens," ASTM Journal of Testing and Evaluation, JTE12508, 33 (1), 527-31 (2005).

Qu, L. W., Y. Lin, D. Hill, B. Zhou, W. Wang, A. Kitaygorodskiy, X. F. Sun, M. Suarez, J. W. Connell, L. F. Allard, and Y. P. Sun, "Polyimide-functionalized carbon nanotubes for nanocomposite thin films," Abstracts of papers of the American Chemical Society 229, U923-U923 Part 2 (March 13, 2005).

Qua, J., P. J. Blau, T. R. Watkins, O. B. Cavin and N. S. Kulkarni, "Friction and wear of titanium alloys sliding against metal, polymer, and ceramic counterfaces," Wear 258 1348-56 (2005).

Ramesh, A., S. N. Melkote, L. F. Allard, L. Riester and T. R. Watkins, "Analysis of white layers formed in hard turning of AISI 52100 steel," Mater. Sci. and Eng. A 390 (1-2) 88-97 (2005).

Rawn, C. J., J. H. Schneibel, and C. L. Fu, "Thermal expansion anisotropy and site occupation of the pseudo-binary molybdenum vanadium silicide $\mathrm{Mo}_{5} \mathrm{Si}_{3}-\mathrm{V}_{5} \mathrm{Si}_{3}$," Acta Mater. 53, 2431-37 (2005).

Roberts, N. W., S. Jaradat, L. S. Hirst, M. S. Thurlow, Y. Wang, S. T. Wang, Z. Q. Liu, C. C. Huang, J. Bai, R. Pindak, and H. F. Gleeson, "Biaxiality and temperature dependence of 3- and 4-layer intermediate smectic-phase structures as revealed by resonant X-ray scattering," Europhys. Lett. 72, 976982 (2005).

Roy, U. N., R. H. Hawrami, Y. Cui, S. Morgan, A. Burger, K. C. Mandal, C. C. Noblitt, S. A. Speakman, K. Rademaker, and S. A. Payne, "Tb" ${ }^{3+}$ doped $\mathrm{KPb}_{2} \mathrm{Br}_{5}$ : Low-energy phonon mid-infrared laser crystal," Appl. Phys. Lett. 86, 151911 (2005). 
Sabau, A. S., J. P. Maria, J. F. Shepard, S. Trollier-McKinstry, T. R. Watkins, and E. A. Payzant, "Piezoelectric properties of $\mathrm{Pb}\left(\mathrm{Mg}_{1 / 3} \mathrm{Nb}_{2 / 3}\right) \mathrm{O}_{3}-\mathrm{PbTiO}_{3}$ epitaxial thin films," Intl. J. of Appl. Ceram. Technol. 2, 51-58 (2005).

Sathyamurthy, S., M. Paranthaman, M. S. Bhuiyan, E. A. Payzant, D. F. Lee, A. Goyal, X. Li, T. Kodenkandath, U. Schoop, and M. Rupich, "Solution deposition approach to high $J_{c}$ coated conductor fabrication," IEEE Trans. Appl. Supercond. 15, 2974-76 (2005)

Sherman, D. H., and L. F. Allard, "Carbide embrittlement in 4330 modified steel," Materials Science and Technology Conf. Proc., New Orleans, Louisiana, September 2004.

Speakman, S. A., M. S. Haluska, S. A. Say, and S. T. Misture, "A reappraisal of fast ion conduction in Ta, Ga, and Al-substituted Aurivillius phases," Solid State Ionics 176, 2617-23 (2005).

Subramaniam, S., M. J. Lance, C. J. Rawn, B. C. Chakoumakos, and A. J. Rondinone, "Raman spectroscopic studies on structure I and structure II trimethylene oxide hydrate," Can. J. Phys. 83, 941-49 (2005).

Sun, N., B. Patterson, J. Suni, E. Simielli, H. Weiland, and L. F. Allard, "Effect of duplex particle structure on recrystallization of twin roll cast AA3105," TMS Letters (December 2004).

Taylor, D. J., and H. M. Meyer III, "Wet-chemical synthesis of zirconium oxyfluoride," Journal of Materials Science 40, 2655-58 (2005).

Truhan, J. J., R. Menon, and P. J. Blau, "The evaluation of various cladding materials for downhole drilling applications using the pin-on-disk test," Wear 259, 1308-13 (2005).

Varga, T., A. P. Wilkinson, M. S. Haluska, and E. A. Payzant, "Preparation and thermal expansion of $\left(\mathrm{M}^{\mathrm{III}}{ }_{0.5} \mathrm{M}^{\prime \mathrm{V}}{ }_{0.5}\right) \mathrm{P}_{2} \mathrm{O}_{7}$ with the cubic $\mathrm{ZrP}_{2} \mathrm{O}_{7}$ structure," J. Sol. St. Chem. 178, 3541-46 (2005).

Wang, H., Z. Feng, and P. S. Sklad, "Inspection and evaluation of laser welds for transit buses," Proc SPIE In't Soc Opt. Eng, 5405, 382-89 (2005).

Williams, P. J., J. J. Biernacki, C. J. Rawn, L. Walker, and J. M. Bai, "Microanalytical and computational analysis of Class F fly ash," ACI Mater. J. 102, 330-37 (2005).

Woo W. C., H. Choo, D. W. Brown, M. A. M. Bourke, Z. Feng S. A. David, C. R. Hubbard, and P. K. Liaw," Deconvoluting the influences of heat and plastic deformation on internal strains generated by friction stir processing," Applied Physics Letters 86, 231902-1-3 (2005).

Yeary, L. W., J. W. Moon, L. J. Love, J. R. Thompson, C. J. Rawn, and T. J. Phelps, "Magnetic properties of bio-synthesized magnetite nanoparticles," IEEE Trans. Magn. 41, 4383-89 (2005).

Zhang, G., K. Chitre, Q. Yang, T. O. Salami, S. R. Oliver, J. Cho, J. Y. Howe, D. W. Coffey, and L. F. Allard, "Synthesis and processing of ceramic films using a nanoscale organic template," Materials Research Society Fall Meeting Poster Session P13.6, Boston, November 30, 2004.

\section{Conference Proceedings}

Bhuiyan, M. S., M. Paranthaman, D. Beach, L. Heatherly, A. Goyal, E. A. Payzant, and K. Salama, "Epitaxial growth of $\mathrm{Eu}_{3} \mathrm{NbO}_{7}$ buffer layers on biaxially textured $\mathrm{Ni}-\mathrm{W}$ substrates," pp. 35-42 in High Temperature Superconductor Materials, Devices, and Applications, ed. M. P. Paranthaman, P. N. Barnes, B. Holzpfel, Y. Yamada, K. Matsumoto, and J. K. F. Yau), Ceramic Trans., 160, ACerS, Westerville, Ohio (2005). 
Gu, Z., J. H. Edgar, E. A. Payzant, H. M. Meyer, L. R. Walker, A. Sarua, and M. Kuball, "Sublimation Growth of aluminum nitride-silicon carbide alloy crystals on SiC (0001) substrates," in GaN, AIN, InN and Their Alloys, ed. C. Wetzel, B. Gil, M. Kuzuhara, and M. Manfra, MRS Proceedings, vol. 831, Materials Research Society, E3. 1 (2005).

Humphreys, A., T. Hassan, C. R. Hubbard, and K. L. Murty, "Ratcheting fatigue failure mechanisms of welded piping joints," Eighteenth Intl Conf on Structural Mechanics in Reactor Technology, Beijing China 8/7-13/05, Published Proceedings (SMIRT 18)-G06-G, 1-9.

Kim, W. K., E. A. Payzant, S. Yoon, T. J. Anderson, O. D. Crisalle, V. Craciun, and S. S. Li, "In-situ investigation on reaction mechanism and kinetics of CulnSe $\mathrm{C}_{2}$ formation from $\mathrm{Cu}-\mathrm{In} / \mathrm{Mo} /$ glass precursor using selenization," pp. 147-48 in DOE Solar Program Review Meeting 2004, DOE/GO-102005-2067, NREL/CD-520-37140 (2005).

Miller, S. F., J. Qu, E. Shi, C. Kao, and A. J. Shih, "Investigation of wire electrical discharge machining of thin cross-sections and compliant mechanisms," Proceedings of 2004 ASME International Mechanical Engineering Congress and Exposition, IMECE2004-60894, Anaheim, CA, Nov. 13-19, 2004.

Porter, W. D., "Analytical models for systematic errors of differential Scanning Calorimetry instruments," Proceedings of ASME Heat Transfer/Fluids Engineering Summer Conference, 525-30 (2005)Speakman, S. A., J. H. Schneibel, D. S. Easton, "An in-situ X-ray diffraction study of the desorption of $\mathrm{TiCl}_{3}$-doped sodium alanate," Materials for Hydrogen Storage2004, ed. T. Vogt, R. Stumpf, M. Heben, and I Robertson, MRS Proceedings Volume 837, N3. 3, MRS, Warrendale, Pa. (2005).

Wiesner, D. J., T. R. Watkins, T. M. Ely, S. Spooner, C. R. Hubbard, and J. C. Williams, "Residual stress measurements of cast aluminum engine blocks using diffraction," pp. 13642 in Advances in X-Ray Analysis, V. 48 CD ROM. Ed. T. C. Huang et al., ICDD, Newtown Square, Pennsylvania (2005).

Woo, W., H. Choo, D. W. Brown, Z. Feng, P. K. Liaw, S. A. David, C. R. Hubbard, and M. A. M. Bourke, "Effect of heat and plastic deformation on the texture of a friction stir processed 6061-T6 aluminum alloy: A neutron diffraction study," Published in the proceedings of the Trends in Welding Conference, Pine Mountain, Georgia, 5/17/-20/05.

\section{Submitted for Publication}

Biernacki, J. J., J. Bai, T. R. Watkins, and C. R. Hubbard, "Meso-scale strain measurements using synchrotron x-rays," To be published as part of Workshop on High Performance Cement-Based Concrete Composition by American Ceramic Society (2005).

Blau, P. J., T. E. Steffner, and J. Qu, "Friction of coated and uncoated amorphous alloys for dental root canal files," J. of Materials Science (submitted).

Chen, Z, R. Trice, H. Wang, W. Porter, J. Howe, M. Besser, and D. Sordelet, "Co-doping of air plasma-sprayed yttria and ceria-stabilized zirconia for thermal barrier applications," Journal of American Ceramic Society (submitted).

Dinwiddie, R. B., R. L. McMasters, W. D. Porter, "Analysis of flash diffusivity experiments performed on semi-porous materials," Thermal Conductivity (submitted).

Dinwiddie, R. B., D. R. Watkins, G. R. Eisele, E. L. Frome, and J. P Watkins, "Infrared thermography to detect deception," Nature (submitted). 
Fawcett, T. G., Faber, J, Needham, F. S. Kabekkodu, C. R. Hubbard, and J. Kaduk, "Developments in formulation analyses," Denver X-ray Conference, Colorado Springs, CO, 8/1/-05/05, Advances in X-ray Analysis (submitted).

Gu, Z., J. H. Edgar, E. A. Payzant, H. M. Meyer, L. R. Walker, A. Sarua, and M. Kuball, "Sublimation growth of aluminum nitride-silicon carbide alloy crystals on $\mathrm{SiC}(0001)$ substrates," MRS Fall Meeting, 2004 (submitted).

Guazzone, F., E. A. Payzant, S. A. Speakman, and Y. H. Ma, "On the alloying process of a PdCu bi-layer: beta phase nucleation" (in internal review).

Gupta, V. K., D. H. Yoon, J. Luo, and H. M. Meyer III, "Preliminary results of activated sintering mechanism and grain boundary pre-wetting/pre-melting in nickel-doped tungsten," in the Proceedings of 107th Annual Meeting of American Ceramic Society (invited), September, 2005 (accepted for publication).

Hubbard, C. R., Y. Sun, F. Tang, L. Lu, H. Choo, and P. K. Liaw, "Changes in lattice strain profiles around a fatigue crack through the retardation period after an overloading, Journal of Physics B (submitted).

Kim, W. K, E. A. Payzant, S. Yoon, and T. J. Anderson, "In situ investigation on selenization kinetics of $\mathrm{Cu}$-In precursor using time-resolved high temperature X-ray diffraction," Appl. Phys. Lett. (submitted).

Lee, K., P. J. Blau, and J. J. Truhan, "Effects of moisture adsorption on laboratory wear measurements of brake friction materials," Wear (under review).

Melcher, C. L. M. P. Maskarinec, M. A. Spurrier, P. Szupryczynski, R. Nutt, L. F. Allard, S. A. Speakman, and D. A. Blom, "Characteristics of $\left(\mathrm{Lu}_{1-\mathrm{x}} \mathrm{Y}_{\mathrm{x}}\right)_{2} \mathrm{SiO}_{5}$ :Ce single crystal scintillators," J. Crystal Growth (submitted).

Payzant E. A., G. M. Stoica, J. Wu, J. Liao, J. E. Spruiell, and P. K. Liaw, "Controlling the microstructures of severely plastic deformed Mg alloy, ZK 660," Advances in X-ray Analysis (submitted).

Porter, W. D., T. W. Wilson, S. A. Speakman, P. K. Liaw, and H. Choo, "Transition metal effects on amorphization and crystallization of ball-milled aluminum alloys," Journal of Appl Physics (submitted).

Qu, J., and P. J Blau, "Scanning acoustic microscopy for characterization of coatings and nearsurface features of ceramics," 30th International Conference \& Exposition on Advanced Ceramics \& Composites, Cocoa Beach, Florida, January 22-27, 2006 (submitted).

Qu, J., T. W. Liao, P. J. Blau, J. E. Shelton, and T. N. Tiegs, "Grindability of TiC-Ni 3 Al metal matrix composites," 30th International Conference \& Exposition on Advanced Ceramics \& Composites, Cocoa Beach, Florida, January 22-27, 2006 (submitted).

Stoica, G. M., E. A. Payzant, L. Wu, H. H. Liao, J. E. Spruiell, and P. K. Liaw, "Development of the microstructure of severely plastically deformed Mg alloy ZK60," Adv. X-ray Analysis (submitted).

Speakman, S. A., W. D. Porter, M. A. Spurrier, and C. L. Melchier, "Thermal Expansion and stability of cerium-doped $\mathrm{Lu}_{2} \mathrm{SiO}_{5}$," Materials Research Bulletin (in press).

Sun, Y., C. R. Hubbard, K. An, F. Tang, Y. L. Lu, H. Choo, and P. K. Liaw, "Characterizing strains near a crack through the retardation period after overload," Physica B (submitted).

Varanasi, V. G., T. M. Besmann, E. A. Payzant, and T. J. Anderson, "Thermodynamic analysis and experimental growth of $\mathrm{ZrO}_{2}$ by chloride CVD," Thin Solid Films (in internal review). 
Wang, H, M. Gustavsson, R. M. Trejo, E. Lara-Curzio, R. B. Dinwiddie, and S. E. Gustafsson, "On the issue of the transient hot strip method for measuring the thermal conductivity of high-conducting thin bars," In'tl J. of Thermophysics (submitted).

Wang, X., B. I. Lee, M. Z.-C. Hu, E. A. Payzant, and D. A. Blom, "Nanocrystalline $\mathrm{BaTiO}_{3}$ powder via ambient conditions sol process," J. Eur. Ceram. Soc. (in press).

Watkins, T. R., M. J. Lance, and J. Kasichainula, "Interfacial characterization and residual stress analysis in diamond films on $\mathrm{LiNbO}_{3}$," Journal of Vacuum Science \& Tech A (submitted).

Watkins, T. R, J. J. Biernacki,. C. J. Parnham, C. R. Hubbard, and J. Bai, "Phased-resolved strain measurements in hydrated ordinary portland cement using synchrotron $\mathrm{X}$ rays, Journal of the American Ceramic Society (submitted).

Webb, L. J., J. S. Biteen, B. S. Brunschwig, A. S. Y. Chan, D. W. Knapp, H. M. Meyer III, D. J. Michalak, E. J. Nemanick, M. C. Traub, and N. S. Lewis, "high resolution soft x-ray photoelectron spectroscopic studies of the air oxidation of alkylated silicon(111) surfaces," JACS (submitted).

Yang, J. J., C. J. Rawn, C-X. Ji, Y. A. Chang, Y. Chen, R. Ragan, D. A. A. Ohlberg, and R. S. Williams, "Thermal expansion coefficient of rare earth metal disilicides and their influence on the growth of disilicide nanowires," Appl. Phys. A (submitted).

Zhang, G., J. Y. Howe, D. W. Coffey, D. A. Blom, L. F. Allard, and J. Cho, "A biomimetic approach to the deposition of $\mathrm{ZrO}_{2}$ films on self-assembled nanoscale templates," Mat. Sci Eng. $C$ (submitted).

\section{Reports}

An, K., C. R. Hubbard, and M. C. Wright, Run-the-System User manual-2nd Generation Neutron Residual Stress Facility, ORNL/TM-2005/531 (2005).

Hubbard, C. R., K. An, User Manual of NRSF2 Process Data Sofwater-2nd Generation Neutron Residual Stress Facility, ORNL/TM-2005/530 (2005).

Ludtka, G. M., P. Kalu, R. A. Jaramillo, Roger A. Kisner, D. M. Nicholson, Gail MackiewiczLudtka, and J. Wilgen, Exploring Ultrahigh Magnetic Field Processing of Materials for Developing Customized Microstructures and Enhanced Performance, Intl Workshop on materials Analysis and Processing in Magnetic Fields, ORNL/TM-2005/79 Final Report (2005).

Wang, H, and T. Mason, G-PLUS Report to Judel Products-Spectra Analysis and Imaging of Colored Glasses, ORNL/TM 2005/91 (2005).

\section{Patents and Invention Disclosures}

Armstrong, T. R., S. A. Speakman, and E. A. Payzant, Solid Oxide Fuel Cell Cathode Material, ORNL invention disclosure approved, U. S. patent application in progress.

E. A. Payzant, T. R. Armstrong, S. A. Speakman, and M. Greenblatt, Low-Temperature Proton Conducting Oxide, U. S. patent application submitted. 


\section{Presentations}

An, K., and M. C. Wright, "Instrument control, data collection, and data real-time analysis software for the ORNL Neutron Residual Stress facility," Presented MECA A-SENS 3 Conf. Santa Fe, New Mexico, 10/17-19/05.

Armstrong, T., and A. Payzant, "Development of supports and membranes for hydrogen separation," 2005 DOE Hydrogen, Fuel Cells \& Infrastructure Technologies Annual Program Review, Washington, DC, May 24-27, 2005.

Armstrong, T., S. A. Speakman, and E. A. Payzant, "Electrical properties of substituted $\mathrm{Ca}_{2} \mathrm{Fe}_{2} \mathrm{O}_{5}$," International Conference on Nonstoichiometric Compounds, Kauai, Hawaii, 3-9 April 2005.

Aronov, M. A., N. I. Kobasko, J. A. Powell, C. R. Hubbard, F. Tang, T. R. Watkins, B. L. Ferguson, and Z. Li, "Effect of intensive quenching on part residual stress conditions," Presented ASM Conference, St. Paul, Minnesota, 8/1-3/05.

Biernacki J. J., R. Wang, J. Bai, M. J. Lance, and C. R. Hubbard, "Direct phase-resolved strain measurements in cementitious materials," 2005 TMS Annual Meeting \& Exhibition, San Francisco, California, American Ceramic Society, 2/13/2005.

Chandra, D., and E. A. Payzant, "Phase stabilities of $\mathrm{Zr}_{2} \mathrm{Fe}$ and $\mathrm{Zr}_{3} \mathrm{Fe}$ hydrides," 54th Annual Denver X-ray Conference. Colorado Springs, Colorado, 8/2/05.

Deng, X, N. Chawla, F. Tang, and I. E. Anderson, "Effect of particle clustering on the fatigue behavior of SiC particle-reinforced Al matrix composites," MS\&T Meeting, Pittsburgh, Pennsylvania, 9/25-28, 2005.

Fawcett, T. G., J. Faber, F. Needham, S. Kabekkodu, J. Kaduk, and C. R. Hubbard, "Developments in formulation analyses by powder diffraction analysis," Denver X-ray Conference, Colorado Springs, Colorado, 8/1-5/05.

Feng, Z., W. Woo, X. L. Wang, C. R. Hubbard, H. Choo, and S. David, "Feasibility of simultaneous-in-situ stress and temperature measurement using neutron diffraction technique," The Minerals, Metals, \& Materials Society, 2005.

Garlea, E., H. Choo, V. O. Garlea, W. B. Bailey, J. R. Santisteban, P. D. Rack, P. K. Liaw, and C. R. Hubbard, "Incoherent neutron scattering measurements of hydrogen-charged Zircaloy-4," SHUG Conference, Oak Ridge, Tennessee. 10/11/2005.

Garlea, E., H. Choo, P. K. Liaw, B. Yang, E. C. Oliver, J. R. Santisteban, D. W. Brown, S. Park, D. A. Smith, P. D. Rack, R. A. Buchanan, and C. R. Hubbard, "X-ray and neutron diffraction phase mapping of hydrogen-charged Zircaloy-4," ICDD Annual Meeting, Philadelphia, Pennsylvania, 3/14-17/05.

Holbery, J. D., R. Jones, R. Williford, J. Abrefah, P. Blau, L. Riester, and T. Gallant, "Surface engineering of sliding contacts in the hydrogen service environment," "Materials for the Hydrogen Economy" symposium, TMS, Materials Science \& Technology, Pittsburgh, Pennsylvania, 9/25-28/05.

Hubbard, C. R., G. B. Sarma, F. Tang, and J. R. Keiser, "Residual strain distribution in bent composite boiler tubes," TAPPI Paper Expo, Milwaukee, Wisconsin, 5/23/05.

Hubbard, C. R., H. Choo, K. An, and W. B. Bailey, "NRSF2 load frame: design control and testing," MECA SENS3 Conference, Santa Fe, New Mexico, 10/17-19/05. 
Hubbard, C. R., A. Stoica, M Wright, S. Craig, W. B. Bailey, F. Tang, and K. An, "Design and performance of the second generation neutron residual stress mapping facility (NRSF2) at ORNL," TMS 2005 Annual Meeting \& Exhibit, San Francisco, California, 2/13-17/05.

Hubbard, C. R., M. A. Aronov, N. J. Kobasko, F. Tang, T. R. Watkins, L. B. Ferguson, and Z. Li, "Effect of intensive quenching on part residual stress conditions," ASM, Heat Treatment Society, Pittsburg, Pennsylvania, 9/25/05.

Hubbard, C R., M. C. Wright, H. Choo, A. D. Stoica, S. O. Craig, W. B. Bailey, F. Tang, and K. An, "The second generation ORNL neutron residual stress mapping facility-the first few months of measurements," MECA-SENS 3 Conf. Santa Fe, New Mexico, 10/17-19/05.

Hubbard, C. R., "Next generation neutron facilities for non-destructive evaluation of residual stress throughout components," SNDE Conference, Brunswick, Maine, 7/31-8/5/05.

Hubbard, C. R., "Requirements for accurate residual stress analysis by the neutron diffraction method," $63^{\text {rd }}$ Pittsburgh Diffraction Conference, Chicago, Illinois, 11/3-5/05.

Hubbard, C. R., G. Sarma, F. Tang, and J. R. Keiser, "Residual strain distribution in bent composite boiler tube," 2005 TMS Meeting, San Francisco, California, 2/13/05.

Hubbard, C. R., E. Garlea, H. Choo, P. K. Liaw, E. C. Oliver, J. R. Santisteban, B. Yang, D. W. Brown, S. Park, D. A. Smith, P. D. Rack, and R. A. Buchanan, "Effect of hydrogen on mechanical behavior of a zirconium alloy," NSF-Europe Grantees Meeting and Forum on Europe-USA collaboration in Matl Res, Strasbourg, France, 5/30/2005.

Hubbard, C. R., F. Tang, T. R. Watkins, M. A. Aronov, N. I. Kobasko, J. A. Powell, B. L. Ferguson, and Z. Li, "Neutron diffraction study of intensive quenching effect on residual stress," MECA SENS 3 Conference, Santa Fe, New Mexico, 10/17-19/05.

Hubbard, C. R., and J. Bai, "Beamline X14A," Tri-Annual PRT Review, BNNL, Upton, New York, 1/31/2005.

Kim, W. K., and E. A. Payzant, "In-situ investigation on reaction kinetics of CulnSe ${ }_{2}$ formation from Cu-In/Mo/glass precursor during selenization," MRS Spring Meeting, San Francisco, California, 4/1/05.

Liaw, P. K., H. Choo, C. R. Hubbard, R. A. Buchanan, and X. L. Wang, "Development of an in-situ neutron-scattering facility for research and education in the mechanical behavior of materials," TMS Annual Meeting, San Francisco, California, 2/13/05.

Patten, J. A., B. Bhattacharya, P. J. Blau, J. Howe, and J. D. Braden, "Ductile regime nanomachining of polycrystalline silicon carbide (6H)," ASPE Annual Meeting, Norfolk, Virginia 10/9-14/05.

Payzant, E. A., F. Tang, C. R. Hubbard, and T. R. Watkins, "The effect of welding process on the residual stress distribution in welded cruciform parts," MECA SENS 3 Conference, Santa Fe, New Mexico, 10/17-19/05.

Payzant, E. A., "Microstructure and ductility of Mg alloy, ZK60, after equal channel angular processing," 54th Annual Denver X-ray Conference. Colorado Springs, Colorado, 8/2/05.

Payzant, E. A., and C. R. Hubbard, "Additional resources for practical and successful hightemperature X-ray diffraction and structural studies by XRD," NSLS Workshop, 1/26/-31/05.

Payzant, E. A., "High-temperature XRD in situ characterization of processing of CulnSe $\mathrm{S}_{2}$ photovoltaic thin films," ACA Annual Meeting, Orlando, Florida, 6/05 (invited). 
Payzant, E. A., "In situ investigation of reaction mechanism and kinetics of CulnSe $\mathrm{S}_{2}$ formation from Culn/Mo/glass precursor during selenization," ICDD Spring Meeting, Philadelphia, Pennsylvania, 3/05.

Rahaman, M. N., J. R. Gross, R. E. Dutton, and H. Wang, "Sintering, phase stability, and thermal conductivity of plasma-sprayed $\mathrm{Gd}_{2} \mathrm{O}_{3}$-stabilized $\mathrm{ZrO}_{2}$," ACerS, Cocoa Beach Meeting, 1/24-27/05.

Truhan, J. J., R. Menon, and P. J. Blau, "The evaluation of various cladding materials for downhole drilling applications using the pin-on-disk test," International Conference on Wear of Materials, San Diego, California, 4/24-28/05.

Wang, H., W. D. Porter, J. Sharp, "Thermal conductivity measurements of bulk thermoelectric materials," ICT05 Conference, Clemson, South Carolina, 06/19/05.

Wang, H., M. Gustavsson, R. B. Dinwiddie, and S. E. Gustafsson, "Temperature distribution during hot disk thermal conductivity measurement studies by infrared imaging," ITCC28\&ITES16, St. Andrews-by-the-Sea, New Brunswick, Canada 6/26-29/05.

Watkins, T. R., L. F. Allard, D. A. Blom, M. J. Lance, H. M. Meyer, L. R. Walker, C. K. Narula, B. Epling, T. Yonushonis, and R. England, "Development of material analysis tools for studying $\mathrm{NO}_{x}$ adsorber catalysts," DEER Conf., Chicago, Illinois, 8/2/05.

Watkins, T. R., "Applications of parallel beam optics at elevated temperatures," Presented $54^{\text {th }}$ Annual Denver X-Ray Conference, 8/1-5/05.

Williams, J. M., C. C. Klepper, R. C. Hazelton, M. D. Keitz, J. E. Lemons, M. Anabtawi, S. Luque, G. M. Ludtka, L. Riester, J. Qu, and J. J. Truhan, Jr., "Boron and boron-based coatings as deposited by the cathodic arc technique," 4th ASM International Surface Engineering Congress \& Exhibition, St. Paul, Minnesota, 8/1-3/05. 


\title{
HTML USER PROGRAM CONTACTS
}

For more information about the User Program, contact

\section{Arvid E. Pasto}

Director

High Temperature Materials Laboratory

Oak Ridge National Laboratory

P.O. Box 2008, Building 4515

1 Bethel Valley Road

Oak Ridge, TN 37831-6062

Phone: 865-574-5123

E-mail: pastoae@ornl.gov

Web site: www.html.ornl.gov

or

\author{
Billie Jean Russell \\ Programs and Marketing Administrator \\ High Temperature Materials Laboratory \\ Oak Ridge National Laboratory \\ P.O. Box 2008, Building 4515 \\ 1 Bethel Valley Road \\ Oak Ridge, TN 37831-6062 \\ Phone (toll-free): 877-603-USER (8737) \\ E-mail: russellbj@ornl.gov \\ Web site: www.html.ornl.gov
}





\section{HTML STAFF AND PHONE NUMBERS}

HTML MAILING ADDRESS

High Temperature Materials Laboratory

Oak Ridge National Laboratory

1 Bethel Valley Road, Post Office Box 2008, Building 4515

Oak Ridge, Tennessee 37831-6062

FAX: (865) 574-4913

\begin{tabular}{|c|c|c|c|c|}
\hline Name & Office No. & Title/Job Description & Phone No. & Email \\
\hline \multicolumn{5}{|c|}{ HTML PROGRAM OFFICE -MAILSTOP 6062} \\
\hline Arvid E. Pasto & 146 & Director of the HTML & $574-5123$ & pastoae@ornl.gov \\
\hline Billie J. Russell & 117 & Programs/Marketing Admin. & $574-1926$ & russellbj@ornl.gov \\
\hline Jessie Whittenbarger & 145 & Program Secretary & $574-8295$ & whittenbarjb@ornl.gov \\
\hline \multicolumn{5}{|c|}{ MATERIALS ANALYSIS USER CENTER -MAILSTOP 6064} \\
\hline Lawrence F. Allard & 157 & Leader & $574-4981$ & allardlfir@ornl.gov \\
\hline Carolyn B. Wells & 159 & Secretary & $574-8765$ & wellscb@ornl.gov \\
\hline Douglas A. Blom & 191 & Research Staff & 241-3898 & blomda@ornl.gov \\
\hline Dorothy W. Coffey & 190 & Research Staff & $576-7688$ & coffeydw@ornl.gov \\
\hline Jane Y. Howe & 4508,273 & Research Staff & $241-9745$ & howej@ornl.gov \\
\hline Harry M.Meyer, III & 192 & Research Staff & $574-5092$ & meyerhmiii@ornl.gov \\
\hline Karren L. More & 163 & Research Staff & $574-7788$ & morek1@ornl.gov \\
\hline Larry R. Walker & 189 & Research Staff & $574-5339$ & walkerlr@ornl.gov \\
\hline \multicolumn{5}{|c|}{ MECHANICAL CHARACTERIZATION AND ANALYSIS USER CENTER - MAILSTOP 6069} \\
\hline Edgar Lara-Curzio & 227 & Leader & $574-1749$ & laracurzioe@ornl.gov \\
\hline Christine M. Goudy & 228 & Secretary & $574-4551$ & goudycm@ornl.gov \\
\hline James G. Hemrick & 233 & Research Staff & $574-7601$ & hemrickjg@ornl.gov \\
\hline Michael J. Lance & 258 & Research Staff & $241-4536$ & lancem@ornl.gov \\
\hline Miladin Radovic & 234 & Research Staff & $574-0034$ & radovicm@ornl.gov \\
\hline Laura Riester & 236 & Research Staff & $574-2588$ & riesterl@ornl.gov \\
\hline Amit Shyam & 253 & Research Staff & $241-4841$ & shyama@ornl.gov \\
\hline Rosa M. Trejo & 236 & Research Staff & $574-5108$ & trejorm@ornl.gov \\
\hline \multicolumn{5}{|c|}{ RESIDUAL STRESS USER CENTER-MAILSTOP 6064} \\
\hline Camden R. Hubbard & 135 & Leader & $574-4472$ & hubbardcr@ornl.gov \\
\hline Geneva N. Worley & 136 & Secretary & $576-0815$ & worleygn@ornl.gov \\
\hline Ke An & 158 & Research Staff & $241-1899$ & kean@ornl.gov \\
\hline W. Barton Bailey & 112 & Research Staff & $574-2122$ & baileywb@ornl.gov \\
\hline O. Burl Cavin & 147 & Research Staff & $574-5121$ & cavino@ornl.gov \\
\hline Hahn Choo* & 133 & Research Staff & $574-3818$ & chooh@ornl.gov \\
\hline Gerald M. Ludtka & 229 & Research Staff & $574-5098$ & ludtkagm1@ornl.gov \\
\hline Fei Tang & 158 & Research Staff & $241-1898$ & tangf@ornl.gov \\
\hline Thomas R. Watkins & 138 & Research Staff & $574-2046$ & watkinstr@ornl.gov \\
\hline \multicolumn{5}{|c|}{ THERMOGRAPHY AND THERMOPHYSICAL PROPERTIES RESEARCH USER CENTER-MAILSTOP 6064} \\
\hline Ralph B. Dinwiddie & 232 & Leader & $574-7599$ & dinwiddierb@ornl.gov \\
\hline Geneva N. Worley & 136 & Secretary & $576-0815$ & worleygn@ornl.gov \\
\hline Roger A. Jaramillo & 255 & Research Staff & $576-3768$ & jaramillora@ornl.gov \\
\hline Wallace D. Porter & 137 & Research Staff & $574-4460$ & porterwd@ornl.gov \\
\hline Hsin Wang & 231 & Research Staff & $576-5074$ & wangh2@ornl.gov \\
\hline \multicolumn{5}{|c|}{ DIFFRACTION USER CENTER-MAILSTOP 6064} \\
\hline E. Andrew Payzant & 113 & Leader & $574-6538$ & payzanta@ornl.gov \\
\hline Geneva N. Worley & 136 & Secretary & $576-0815$ & worleygn@ornl.gov \\
\hline Jianming Bai & 136 & Research Staff & $576-0815$ & baij@ornl.gov \\
\hline Roberta A. Meisner & 132 & Research Staff & $576-9480$ & meisnerra@ornl.gov \\
\hline Claudia J. Rawn & 139 & Research Staff & $574-3184$ & rawncj@ornl.gov \\
\hline \multicolumn{5}{|c|}{ FRICTION, WEAR, AND MACHINABILITY USER CENTER-MAILSTOP 6063} \\
\hline Peter J. Blau & 107 & Leader & $574-5377$ & blaupj@ornl.gov \\
\hline Christine M. Goudy & 110 & Secretary & $574-4551$ & Goudycm@ornl.gov \\
\hline Ronald $\mathrm{H}$. Chand & 116 & Research Staff & $574-3123$ & chandrh@ornl.gov \\
\hline Randy J. Parten & 230 & Research Staff & $574-5444$ & partenrj@ornl.gov \\
\hline Jun Qu & 235 & Research Staff & $576-9304$ & qujn@ornl.gov \\
\hline John J. Truhan, Jr. & 129 & Research Staff & $574-1057$ & truhaniiir@ornl.gov \\
\hline
\end{tabular}

*UT-ORNL Joint Faculty. 



\section{FRONT COVER}

The images from stereo pairs show qualitative and quantitative topographic information about the surface of the specimen.

\section{BACK COVER}

$\mathrm{Ba}_{3} \mathrm{MM}_{2} \mathrm{O}_{9}\left(\mathrm{M}=\mathrm{Mg}, \mathrm{Ni}, \mathrm{Zn} ; \mathrm{M}^{\prime}=\mathrm{Nb}, \mathrm{Ta}\right)$ phases have a suitable combination of properties desirable for wireless communication applications. The atomic structure shown is of $\mathrm{Ba}_{3} \mathrm{NiTa}_{2} \mathrm{O}_{9}$ where the $\mathrm{M}$ and $\mathrm{M}^{\prime}$ cations are ordered resulting in trigonal symmetry. 

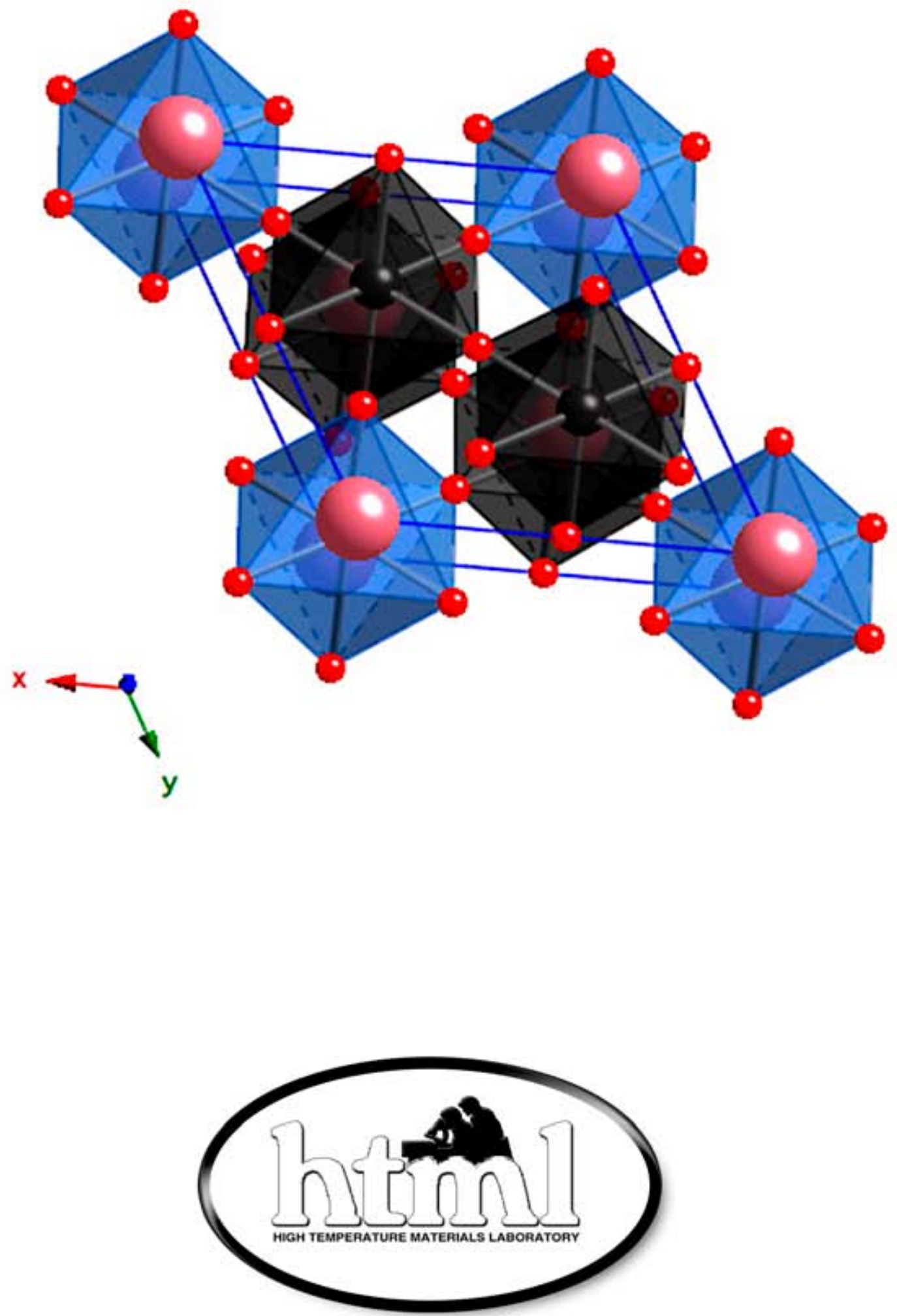